\title{
Biológiai mozgások modellezése fénnyel készített és fénnyel hajtott mikrorobotok segítségével
}

\author{
$\mathrm{PhD}$ értekezés
}

\author{
Buzás András
}

Témavezető:

Dr. Ormos Pál

\author{
Fizika Doktori Iskola \\ MTA Szegedi Biológiai Kutatóközpont Biofizikai Intézet \\ Természettudományi és Informatikai Kar \\ Szegedi Tudományegyetem
}

2019

Szeged 



\section{Tartalomjegyzék}

1. Rövidítések............................................................................................................ 4

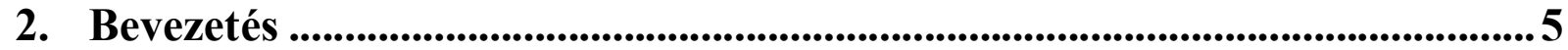

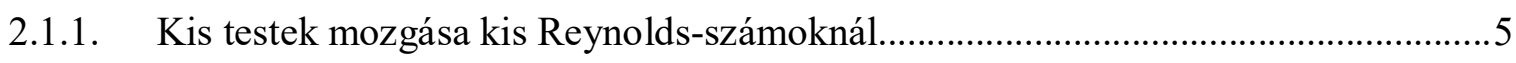

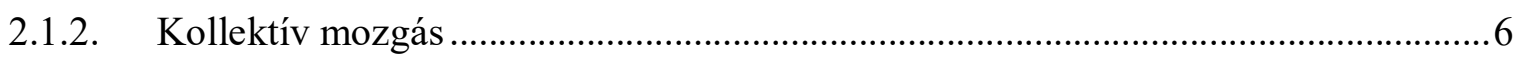

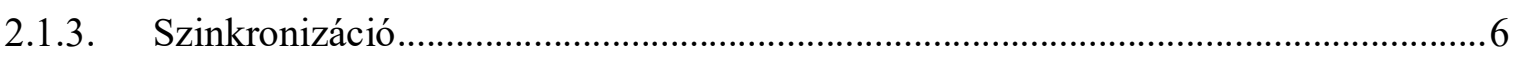

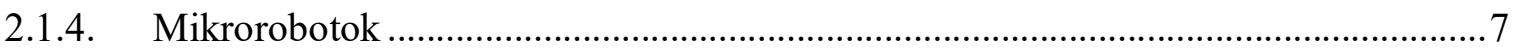

2.2. A hidrodinamika alapjai ..............................................................................................................10

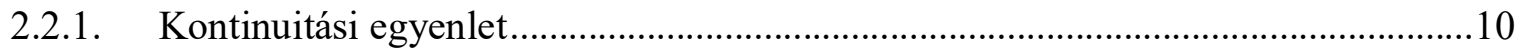

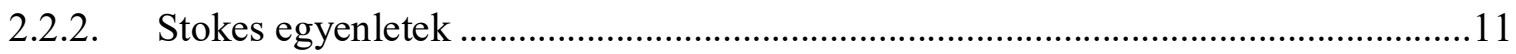

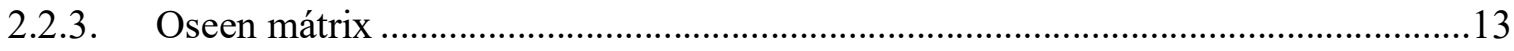

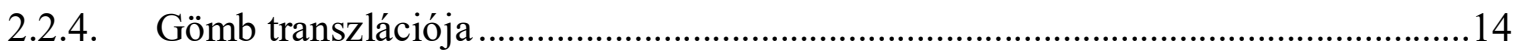

2.2.5. Biológiai mozgások az alacsony Reynolds számok tartományában .........................14

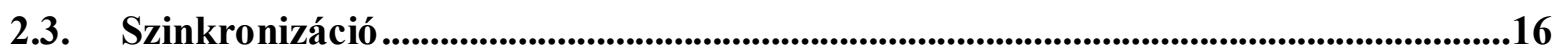

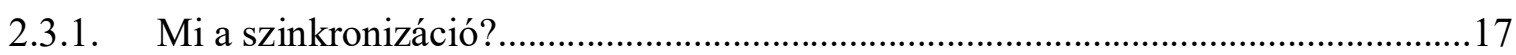

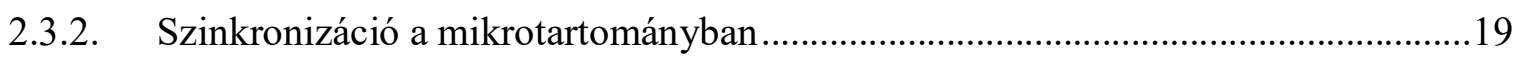

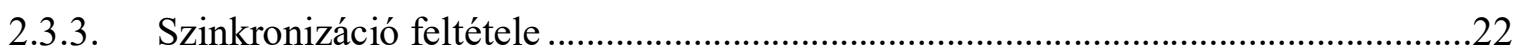

2.3.4. A hidrodinamikai szinkronizáció egyszerü modellje ..............................................23

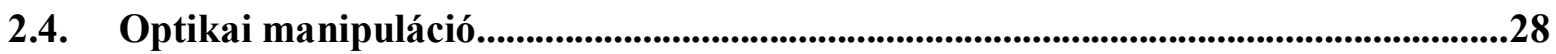

2.4.1. Az optikai manipuláció történeti áttekintése .............................................................28

2.4.2. Az optikai manipuláció elméleti háttere .......................................................................

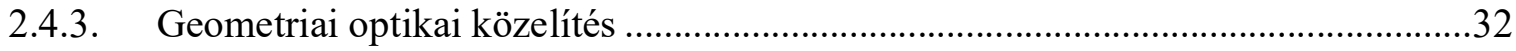

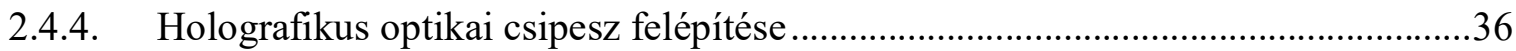

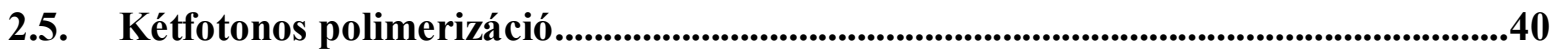

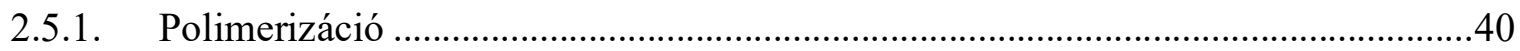

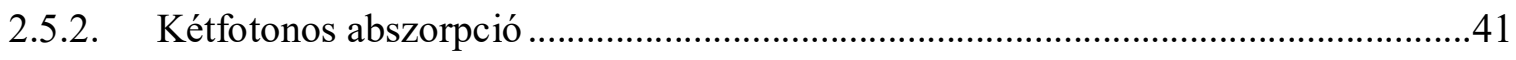

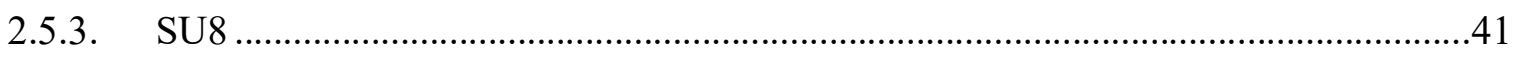

3. Célkitúzés .....................................................................................................443

3.1. Fénnyel hajtott, autonóm módon mozgó mikroszkopikus testek. ...............................43 


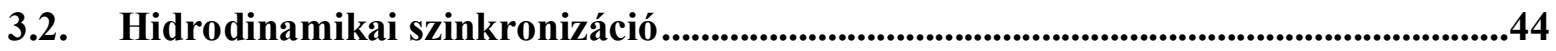

4. Elmélet .............................................................................................................45

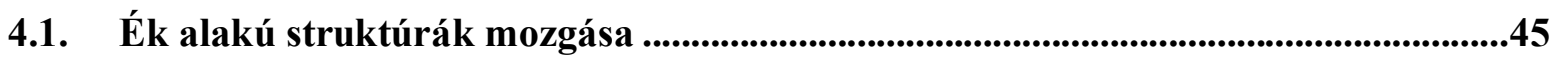

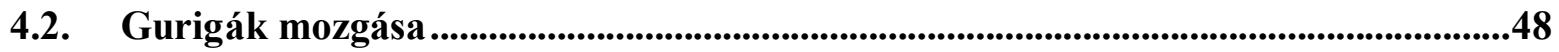

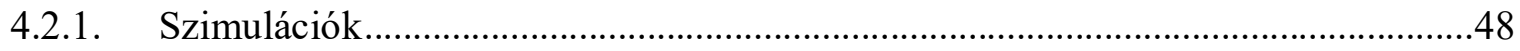

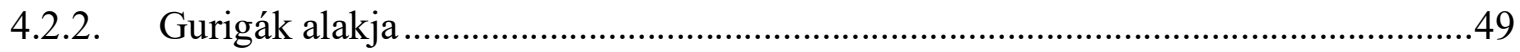

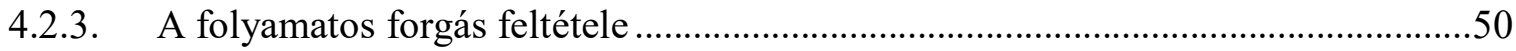

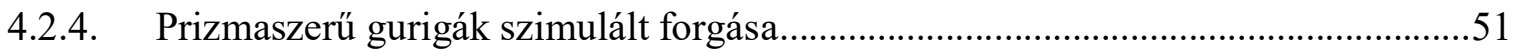

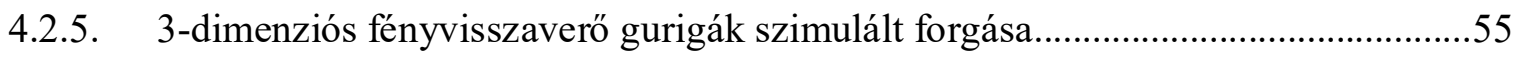

5. Kísérleti körülmények és vizsgálati módszerek ......................................56

5.1. Struktúrák elóállítása ......................................................................................................56

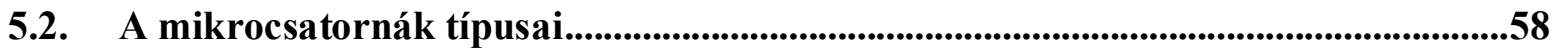

5.3. Ékek és gurigák előkészítése ............................................................................................59

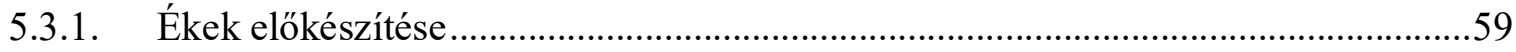

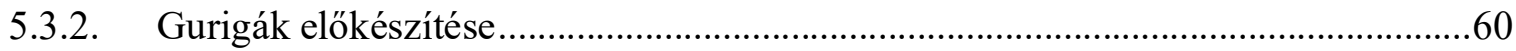

5.3.3. Ékek és gurigák megfigyelésére használt kísérleti elrendezés................................61

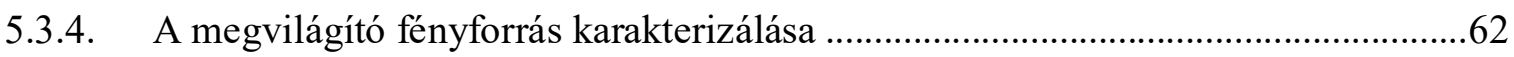

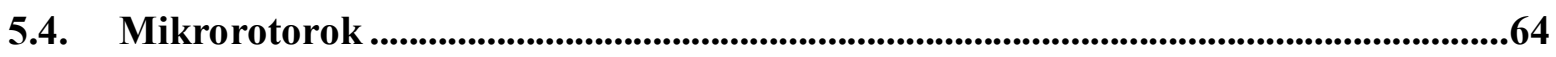

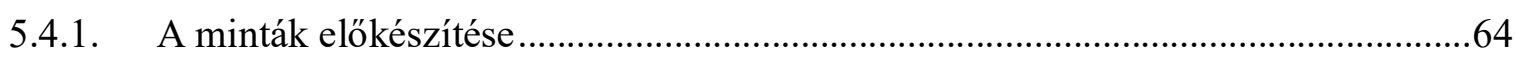

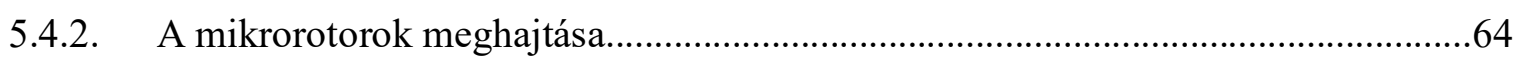

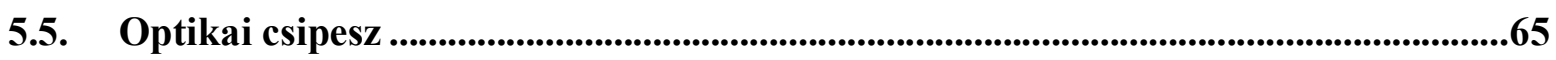

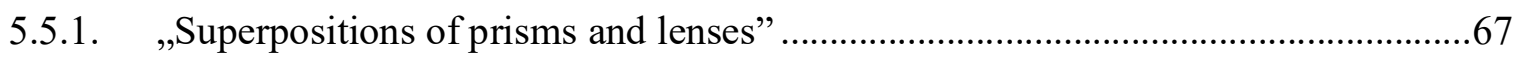

5.6. A filmek kiértékelése........................................................................................................69

5.6.1. Ékek és gurigák transzlációjának és rotációjának meghatározása.............................69

5.6.2. Rotorok transzlációjának és orientációjának meghatározása......................................70

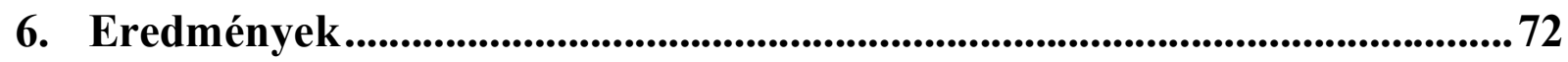

6.1. Kísérletek az ék alakú mikrorobotokkal ..........................................................................72

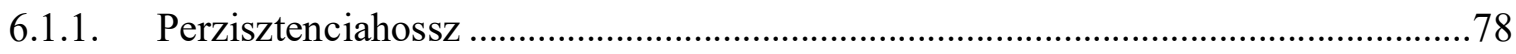

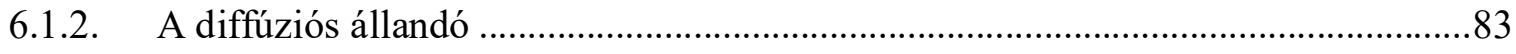

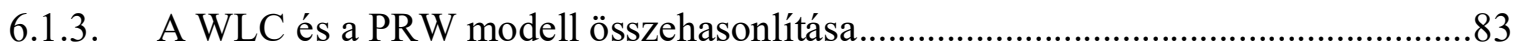

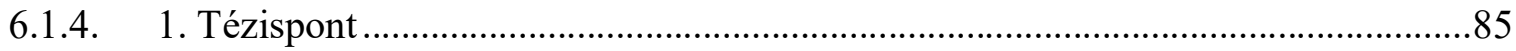


6.2. Kísérletek gurigákkal.........................................................................................................86

6.2.1. Az inhomogén megvilágítás esetleges hatása a guriga mozgására............................8

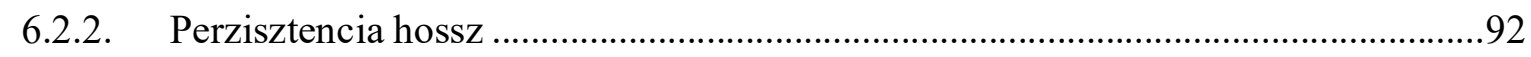

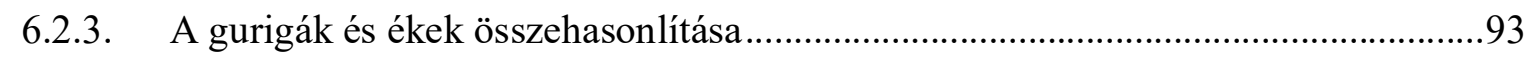

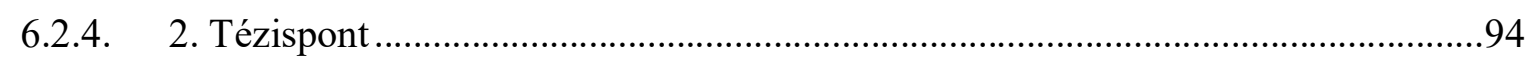

6.3. Fényindukált forgás általános feltétele ...................................................................95

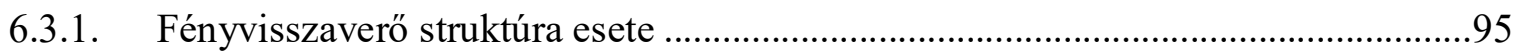

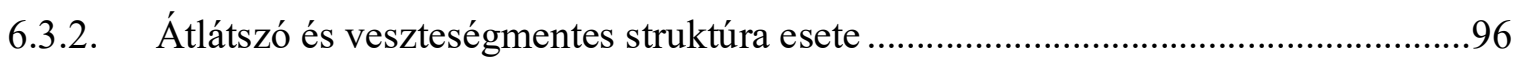

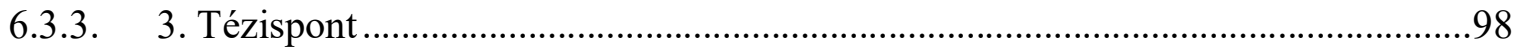

6.4. Hidrodinamikai szinkronizáció ................................................................................99

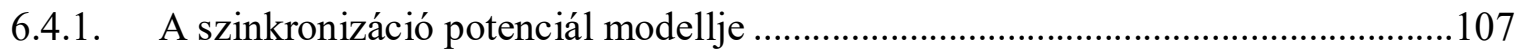

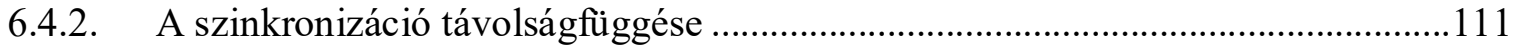

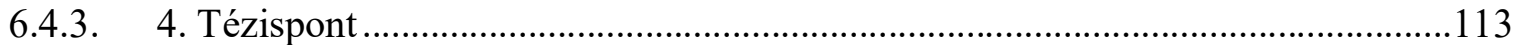

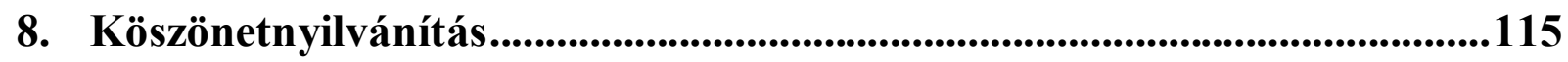

9. Irodalomjegyzék ..........................................................................................................116

10. Magyar nyelvü összefoglaló .................................................................................127

11. Angol nyelvü összefoglaló ...........................................................................130 


\section{Rövidítések}

$\begin{array}{ll}\text { ATP } & \text { adenozin trifoszfát } \\ C R & \text { Chlamydomonas reinhardtii } \\ R e & \text { Reynolds szám } \\ \text { SLM } & \text { Spatial Light Modulator } \\ \text { TPP } & \text { two-photon polymerization } \\ \text { WLC } & \text { Worm-like chain } \\ \text { PRW } & \text { Persistent random walk }\end{array}$




\section{Bevezetés}

A mikroszkopikus biológiai rendszerek mozgása nagyon különbözik attól, ahogy a makro világunkban látott testek mozognak. E kérdéskör rendkívül érdekes és fontos mind elméleti, mind pedig gyakorlati szempontból, és számos, szerteágazó, jellegzetes kérdéskört érint. Nagyon fontos gyakorlati cél például a bakteriális fertőzések megelőzése, legyőzése. Ehhez a fertőzés folyamatának pontos jellemzése szükséges. A baktériumok (egyedi, illetve nagyszámú egyed együttes) mozgásának jobb megismerése nyilvánvalóan közelebb visz a problémakör kezeléséhez. Általában igaz, mára nyilvánvalóvá vált, hogy a makroszkopikus biológiai jelenségek megértéséhez elengedhetetlen, hogy megismerjük a mikroszkopikus folyamatok részleteit. A baktériumok mozgása sajátos fizikai problémakör. Ismert, hogy a kis Reynolds-számmal jellemezhető rendszerekben az úszás mechanizmusa nagyon más, mint a makroszkopikus világban, a lehetséges megvalósulások részletes jellemzése még távolról sem teljes. Sok érdekes hatást is megfigyeltek e világban, pl. az egymás közelében mozgó részecskék hidrodinamikai kölcsönhatása, kollektív mozgása, bizonyos mozgások szinkronizációja, stb. - szükség lenne e jelenségek nagy pontosságú jellemzésére, kvantitatív leírására. Az élő rendszereken végezhető kísérletek lehetőségei korlátozottak, hiszen a paraméterek nem mindig ismertek, nem is változtathatók tetszőlegesen, vagyis a fizikai modellalkotáshoz szükséges kísérleti adatokat nem mindig lehet megszerezni. A mozgó rendszerek részletes jellemzésében nagy segítséget nyújtanának olyan mesterséges modellek, amelyek a természetes rendszerek működését lehetőleg minél több szempontból hủen reprezentálják, ugyanakkor paramétereik pontosan ismertek, változtathatók, ezáltal az elméleti modellek ellenőrizhetősége könnyebbé válik. Ilyen rendszerek fejlesztését és alkalmazását tüztem ki célul. A dolgozatom alapjául szolgáló jelenségeket, területeket az alábbiakban röviden bemutatom.

\subsubsection{Kis testek mozgása kis Reynolds-számoknál}

A jellemzően mikrométeres méretű testek kis Reynolds-számokkal jellemzett mozgásának két markáns jellegzetessége van. Egyrészt, a viszkózus erőkhöz képest a tehetetlenség elhanyagolható, a mozgásegyenletek ennek megfelelően módosulnak. Emellett, a mikronos méretek miatt aránylag nagymértékű a Brown-fluktuáció, a mozgást mindig ez kíséri. Mindezek következtében a mozgás 
és a meghajtás mechanizmusa teljesen más, mint a makro világban. Bizonyos, a makro világban elterjedt hatásos úszási mód teljesen hatástalan a mikrovilágban, és megfordítva, egészen meglepő mikroszkopikus meghajtási módok alakultak ki [1].

\subsubsection{Kollektív mozgás}

A biológiai mozgások egyik igen széles jelenségköre a kollektív mozgás, amely mind mikroszkopikus, mind makroszkopikus mérettartományban megfigyelhető. A kollektív mozgások legföbb tulajdonsága, hogy az egyed viselkedését a "többség" hatása határozza meg - az egyed teljesen eltérő viselkedést mutat ahhoz képest, mintha “magában” lenne. E jelenség kialakulásához az szükséges, hogy nagyszámú egyed tartózkodjon egymáshoz közel s valamilyen kölcsönhatás legyen közöttük. Ilyenkor érdekes rendeződési folyamat megy végbe a teljes rendszeren, aminek során az egyedek közel egyszerre megváltoztatják a viselkedésüket és a teljes rendszerre kiterjedően kialakul egy mintázat.

A kollektív mozgások egyik meghatározó tényezője a kölcsönhatás, ami makroszkopikusan teljesen eltérő alapokon nyugodhat, mint a mikroszkopikus tartományban. Például madarak viselkedésénél jellemzően egy „tudatos” követési/elkerülési folyamat eredménye, míg baktériumok esetében jellemzően hidrodinamikai, kémiai, vagy mechanikai kölcsönhatások játsszák a döntő szerepet. Annak ellenére, hogy a kölcsönhatást igen eltérő folyamatok határozhatják meg, a különböző rendszerekben kialakuló mintázat gyakran nagyon hasonló.

A kollektív mozgások kísérleti vizsgálata kezdetben a természetben előforduló jelenségek megfigyelésével történt. Az utóbbi évtizedben a technológia fejlődése nagy változásokat hozott e vizsgálatokban. Egyrészt a fejlett helymeghatározó és mozgáskövető rendszerek, illetve az eszközök kis mérete, másrészt az önmüködő mesterséges objektumok, robotok széles körü elterjedése új lendületet adott e kutatási iránynak [2].

\subsubsection{Szinkronizáció}

A biológiai mozgások egy másik jelenségköre, és amely az utóbbi években igen intenzív kutatások tárgya, a szinkronizáció. Szinkronizáció során két, vagy több (bizonyos adott frekvenciájú) ciklikus müködésű rendszer kölcsönhatása következtében az egyes rendszerek frekvenciája megváltozik, és azonos frekvencián kezdenek müködni. A mikrovilágban a szinkronizáció 
megjelenése létfontosságú a sejtek, baktériumok, mikroszkopikus élölények helyváltoztató mozgásában vagy szerveinek müködésében, konkrét példaként említhetjük a bakteriális flagellumok szinkronizált müködését, vagy a sejtek csillóinak együttes mozgását, illetve a rajtuk áthaladó hullámok (metachronal wave) kialakulását [3, 4].

A szinkronizációt létrehozó kölcsönhatás sokféle lehet. Számos elméleti munka szerint a mikrobiológiai rendszerekben a hidrodinamikai kölcsönhatásnak is fontos szerep juthat, azonban a „teljes kép” a szinkronizáció kialakulásának folyamatáról az alacsony Reynold számok tartományában még mindig tisztázatlan.

\subsubsection{Mikrorobotok}

Mindhárom említett jelenségkörben kulcsszerepe van a folyamatok kísérleti vizsgálatának, amelyek egyrészt alapul szolgálnak az elméletek létrehozásához, másrészt az elméletek ellenőrzését is a megfelelő kísérletekkel lehet elvégezni.

A teljes leíráshoz szükséges kísérleteket elvileg a természetes rendszereken legjobb végezni. A természetes rendszereken végzett kísérleteknek azonban lényeges korlátja, hogy ezek általában nagyon bonyolultak, számos paraméterük nem ismert elegendő pontossággal. Ráadásul, a fizikai modellek ellenőrzéséhez általában szükséges a paraméterek változtatása - a természetes rendszereken erre rendszerint csak nagyon korlátozottan van lehetőség. Ilyen problémák nagyban megnehezítik a kvantitatív modellalkotást. A probléma egyik magától értetődő megoldása mesterséges kísérleti modellrendszer, robotok alkalmazása. A mozgó rendszerek részletes jellemzésében nagy segítséget nyújtanának olyan mesterséges modellek, amelyek a természetes müködést lehetőleg minél több szempontból hủen reprezentálják, ugyanakkor paramétereik pontosan ismertek, változtathatók.

A mikroszkopikus robotok ráadásul az alapkutatáson túl óriási gyakorlati jelentőséggel bírnak. Intenzív kutatások folynak e technológia alkalmazására föleg az orvosbiológia területén, olyan feladatok ellátására, mint az irányított gyógyszerszállítás, anyagtranszport, vagy helyi diagnosztika.

Említettem, hogy a kollektív viselkedés mind a makro, mind a mikrovilágban megjelenik. Közbevetőleg ezért ismertetem, hogy makroszkopikus viszonyokra vonatkozóan a robotokat már a 80-es évek óta alkalmazzák a kollektív mozgás modellezésére [5], amelyek segítségével akár 2 dimenzióban (pl.: felületen gördülő robotok, medencében úszó hajók segítségével) [6], akár 3 
dimenzióban (pl.: helikopterek segítségével) [7, 8] megfigyeltek kollektív jelenségeket. Noha számos elönye van ezeknek a kísérleteknek, mint például, hogy tetszőleges kölcsönhatás beprogramozható, e rendszerek müködtetése bonyolult, költséges, körülményes, és nagy „térfogatot” igényel, ráadásul a kísérletekben résztvevő robotok száma tipikusan néhány tucatra, vagy 100-ra limitált [2].

$\mathrm{Az}$ előbbiek miatt tehát e jelenségtípus esetén is számos előnnyel járna a releváns kísérletek elvégzése a mikroszkopikus mérettartományban. Óriási számban és minimális térfogaton - akár $10^{4}-10^{5} \mathrm{db}$ egység is elhelyezhető igen kis térfogatban - lehetne elvégezni a kísérleteket, amelyek új dimenziókat nyitnának a kollektív mozgások kontrollált kísérleti vizsgálatában. A mikroszkopikusan kialakuló szinkronizáció kísérleti vizsgálatára szintén egy autonóm és ciklikus müködésü „mikrorobot” a legalkalmasabb, amelynek fontosabb paraméterei, mint például a mérete, működési frekvenciája, geometriája, stb. szabadon változtatható. A számos elméleti munka mellett kontrollált kísérletet a mikroszkopikus tartományban nem végeztek, éppen ezért az elméletek kísérleti alátámasztása nem történt meg.

Egyszerüsége és a benne rejlő potenciál miatt az utóbbi időben komoly erőfeszítések történtek a mikroszkopikus robotok fejlesztése terén. Számos megoldás született a mikro és nanoméretü részecskék transzport folyamatainak befolyásolására, mint például az elektroforézis [9], magnetoforézis [10,11], termoforézis [12] (hőmérséklet gradiens hatására bekövetkező áramlás), vagy diffúzióforézis [13, 14, 15] (koncentráció gradiens hatására bekövetkező áramlás). Ezekben a módszerekben azonban a külső tér alkalmazása jelentősen behatárolja a részecskék mozgását, és nem beszélhetünk függetlenül mozgó objektumokról, hiszen a mozgás irányát a gradiensek iránya határozza meg. Alapvetően eltérő megközelítés az optikai csapdázás használata, amivel akár nanométer pontosságú precizitás is elérhető, azonban nagy hátránya hogy minden egyes objektumot, vagy az objektumok csoportját külön-külön kell vezérelni [16,17], és a mozgás iránya itt sem független a környezettől.

Az autonóm módon mozgó mikro-objektumokkal kapcsolatos legnagyobb kihívás az, hogy biztosítani kell a mozgáshoz szükséges energiát. Ennek megvalósítására változatos megoldások születtek. Leggyakoribb megközelítés, amikor „tisztán” kémiai reakcióból nyert energia alakul át mechanikai energiává: ez történhet motorfehérjék alkalmazásával, illetve disszipatív és katalitikus rendszerekben [18], illetve amikor fényindukált kémiai reakcióból nyeri a mikro-úszó a mozgásához szükséges energiát [19]. 
A nem kémiai megoldásokból már jóval kevesebb létezik. Fényindukált termoforézis segítségével mozog a Janus-részecske: ennek a felszíne két elkülönülő tartományból áll, egyik fele arany, a másik fele szilícium. A felszínét homogén módon kivilágítva a különböző oldalon eltérő mértékben fellépő fényabszorpció hőmérséklet-gradiens kialakulásához vezet, ami a részecskét mozgásba hozza [20]. A hagyományos termoforézissel szemben a Janus részecske autonóm módon mozog, hiszen nem külső tényező, hanem a részecske orientációja határozza meg a lokális gradiens és így a mozgás irányát.

A dolgozatomban bemutatott munkában fénnyel készített és fénnyel hajtott mikroszkopikus robotrendszer kidolgozását tűztem ki célul. Az eljárást alkalmaztam a fenti mozgásformák részletes jellemzésére. A kidolgozott eljárás viszonylag egyszerü, képes a feltételek teljesítésére, illetve mód van a rendszer pontos fizikai jellemzésére. 


\subsection{A hidrodinamika alapjai}

A hidrodinamikai kölcsönhatás jelentős szerepet játszik minden esetben, amikor két vagy több részecske mozog a folyadékban. Igaz ez abban az esetben is, ha biológiai rendszereket, sejteket, sejtalkotókat, vagy akár molekulákat vizsgálunk. Ráadásul a hidrodinamikai kölcsönhatás a sejtek mérettartományában igen jelentős, és a méretükhöz viszonyítva igen nagy távolságra képes kifejteni hatását. Emiatt a biológiai mozgások vizsgálata során kulcsfontosságú a hidrodinamika megértése és figyelembe vétele. Az alábbi fejezet rövid áttekintést ad a hidrodinamika alapjairól a mikroszkopikus mérettartományban [21,22].

A hidrodinamika a folyadék mozgásának olyan tárgyalásmódja, ahol a molekuláris szintü folyamatokat nem vesszük figyelembe. A folyadék állapotát a lokális sebesség $\boldsymbol{u}(\boldsymbol{r}, t)$, a nyomás $p(\boldsymbol{r}, t)$ és a folyadék sürüsége $\rho(\boldsymbol{r}, t)$ írja le, ahol $\boldsymbol{r}$ a folyadékon belüli pozíció egy adott $t$ időpillanatban. A fenti mennyiségeket az adott $t$ időpillanatban $\boldsymbol{r}$ pont körüli kis térfogatelemre vett átlagok adják. A térfogatelem olyan kicsi, amelyen belül nem változik jelentősen a folyadék állapota, viszont lényegesen nagyobb, mint a folyadékot alkotó molekulák mérete. Az alábbi leírásban a hőmérséklet hatását elhanyagoljuk, tehát a hőmérséklet állandó a folyadék teljes térfogatára nézve és feltételezzük, hogy a lejátszódó folyamatok (súrlódás, disszipáció,...) nem változtatják meg a folyadék hőmérsékletét. A folyadék sűrüségét időben állandónak tekintjük, másrészt feltételezzük, hogy a folyadékban nem lépnek fel olyan nyomásviszonyok, amelyek megváltoztatják a folyadék sürüségét, így összenyomhatatlan folyadékként kezeljük (összenyomhatatlan folyadékra jó példa a biológiai mozgások leggyakoribb közege, a víz is).

\subsubsection{Kontinuitási egyenlet}

A kontinuitási egyenlet a tömegmegmaradást fejezi ki áramló folyadékok esetén. A tér egy adott pontjában a folyadék sűrüsége $\rho(\boldsymbol{r}, t)$ illetve a sebességmező $\boldsymbol{u}(\boldsymbol{r}, t)$ közötti kapcsolatot az alábbi egyenlet írja le [21,22]:

$$
\frac{\partial \rho}{\partial t}+\nabla \cdot(\rho \boldsymbol{u})=0
$$

Összenyomhatatlan folyadékok esetén a sürüség sem az idő, sem a hely függvényében nem változik, $\rho(\boldsymbol{r}, t)=\rho$, így a kontinuitási egyenlet az alábbi alakra egyszerüsödik:

$$
\nabla \cdot \boldsymbol{u}=0
$$




\subsubsection{Stokes egyenletek}

A Navier - Stokes egyenlet a Newton féle mozgásegyenletek megfogalmazása folyadékokra vonatkozóan [21]: azt fejezi ki, hogy egy infinitezimálisan kis folyadék térfogatelem impulzusának megváltozása egyenlő a rá ható erők eredőjével:

$$
\frac{\partial \boldsymbol{u}}{\partial t}+\boldsymbol{u} \cdot \nabla \otimes \boldsymbol{u}=-\frac{1}{\rho} \nabla p+\frac{\eta}{\rho} \nabla^{2} \boldsymbol{u}+\frac{\boldsymbol{f}}{\rho}
$$

Az egyenlet bal oldala a folyadékelem gyorsulását fejezi ki, ami nem csak a $\partial u / \partial t$ explicit gyorsulást, hanem a folyadék konvektív gyorsulását is figyelembe veszi (ahol $\nabla \otimes \boldsymbol{u}$ diadikus szorzatot jelöl). Az egyenlet jobb oldala a folyadékelemre ható összes erőt jelöli, ez a külső erőket $(f)$, a nyomást $(p)$, illetve a nyírófeszültség változást foglalja magába. $\eta$ a folyadék viszkozitása. A (3) egyenletben az egyes tagok szerepe a különböző hidrodinamikai problémák megoldása során igen eltérő lehet. Mivel vizsgálódásaim a mikroszkopikus mérettartományra korlátozódnak, érdemes megvizsgálni, mely tagok játsszák a domináns szerepet. A (3) egyenletet célszerú átalakítani olyan módon, hogy dimenzió nélküli paramétereket vezetünk be. A mikroszkopikus tartomány vizsgálata során a jellemző méretek $a \sim \mu \mathrm{m}$, míg a sebességek $v \sim \mu \mathrm{m} / \mathrm{s}$ nagyságrendjébe esnek. Bevezetve $\tilde{\boldsymbol{r}}=\boldsymbol{r} / a, \tilde{\boldsymbol{u}}=\boldsymbol{u} / v, \tilde{t}=t / \tau$, ahol $\tau$ a vizsgált időtartomány nagyságrendje (tipikusan nagyobb, mint $m s$ ), a dimenziómentes Navier-Stokes egyenlet az alábbi alakot ölti:

$$
\frac{\rho a^{2}}{\eta \tau} \frac{\partial \tilde{\boldsymbol{u}}}{\partial \tilde{t}}+R e \cdot \tilde{\boldsymbol{u}} \cdot \tilde{\nabla} \otimes \tilde{\boldsymbol{u}}=\eta \tilde{\nabla}^{2} \tilde{\boldsymbol{u}}-\tilde{\nabla} \tilde{p}+\tilde{\boldsymbol{f}}
$$

ahol $\tilde{p}=p /(\eta v / a)$ és $\tilde{\boldsymbol{f}}=\boldsymbol{f} /\left(\eta v / a^{2}\right)$. Az Re dimenziómentes paraméter a Reynolds-szám, ami az alábbi alakban fejezhető ki:

$$
\operatorname{Re}=\frac{\rho v a}{\eta}
$$

A Reynolds-szám könnyen értelmezhető, ha figyelembe vesszük, hogy a viszkózus erök jellemzően az $\eta v / a^{2}$, míg a tehetetlenségi erők a $\rho v^{2} / a$ nagyságrendjébe esnek. Így a Reynoldsszám a tehetetlenségi és viszkózus erők hányadosát jellemzi. A biológiai mozgások során vízben a fenti méret- és sebességtartományokat figyelembe véve értéke $10^{-4}$ és $10^{-6}$ között változik. Ez 
annyit jelent, hogy a tehetetlenségi erők nagyságrendekkel kisebbek, mint a viszkózus erők és így a második tag a (4) egyenlet bal oldalán elhanyagolható. Ekkor a Navier-Stokes egyenlet az alábbi alakra egyszerüsödik:

$$
\frac{\rho a^{2}}{\eta \tau} \frac{\partial \tilde{\boldsymbol{u}}}{\partial \tilde{t}}=\eta \tilde{\nabla}^{2} \tilde{\boldsymbol{u}}-\tilde{\nabla} \tilde{p}+\tilde{\boldsymbol{f}}
$$

Ezen felül meg kell még vizsgálni, milyen karakterisztikus idők jelennek meg a mikroszkopikus mérettartományban. Az egyik legjellemzőbb idő az, ami alatt a mikroszkopikus részecskék elveszítik impulzusukat a folyadékkal történő súrlódás hatására. Egy m tömegü részecske mozgásegyenlete $\zeta$ súrlódás esetén $m \dot{v}=-\zeta v$, amiből a relaxációs idő $\tau_{r}=m / \zeta$, ahol $m=\rho_{p} \frac{4}{3} \pi a^{3}, \rho_{p}$ a részecske sürüsége, ez nagyságrendileg megegyezik a víz sürüségével. A mikrométeres mérettartományba eső gömbalakú részecskét feltételezve, és a súrlódás kifejezésére felhasználva a Stokes-féle ellenállás törvényt, $\zeta=6 \pi \eta a$, valamint kifejezve a relaxációs időt $\tau_{r}=\frac{2}{9} \frac{\rho_{p} a^{2}}{\eta}$, ami 100ns nagyságrendü, ekkor az egyenlet bal oldala az alábbi módon írható:

$$
\frac{9}{2} \frac{\rho}{\rho_{p}} \frac{\tau_{r}}{\tau} \frac{\partial \tilde{\boldsymbol{u}}}{\partial \tilde{t}}=\eta \tilde{\nabla}^{2} \tilde{\boldsymbol{u}}-\tilde{\nabla} \tilde{p}+\tilde{\boldsymbol{f}}
$$

Mivel a kísérletileg vizsgált folyamatok $(\tau)$ általában $1 \mathrm{~ms}$-nál hosszabbak, a részecskék gyorsulása a túlcsillapítás következtében 0, a (7) egyenlet bal oldala elhanyagolható. Így kapjuk meg a Stokesegyenleteket:

$$
\begin{gathered}
\eta \nabla^{2} \boldsymbol{u}-\nabla p+\boldsymbol{f}=0 \\
\nabla \cdot \boldsymbol{u}=0
\end{gathered}
$$

Összegezve, az alacsony Reynolds szám és a túlcsillapítás miatt a tehetetlenség az egyenletekben elhanyagolható.

Folyadékba merülő részecskék között a kölcsönhatás (impulzusának átadása) két mechanizmus szerint történhet, amelyek eltérő időskálán müködnek. Egyrészt, a részecske kezdeti impulzusának egy részét a részecske körül keletkező gömbhullámként terjedő hanghullámok szállítják és $\tau_{s}=r / c$ idő alatt érik el az $r$ távolságban lévő szomszédos részecskét, ahol c a hangsebesség a folyadékban. Másrészt, örvényáram keletkezik a részecske körül, amely az $r$ távolságban lévő szomszédos 
részecskét $\tau_{v}=r^{2} \cdot v$ idő alatt éri el, ahol $v=\eta / \rho$ a kinematikai viszkozitás. A két mechanizmus által meghatározott karakterisztikus idők pl. $10 \mu \mathrm{m}$-es részecsketávolság esetén $\tau_{s} \sim 0.1$ ns, míg a $\tau_{v} \sim 0.1 \mathrm{~ms}$ nagyságrendjébe esik. Kísérletek azt mutatják, hogy az impulzusátadás karakterisztikus ideje sokkal rövidebb, mint $\tau_{\nu}$, tehát a kölcsönhatást dominánsan a hangsebesség közvetíti [21, 23], és ezek alapján a kísérletek tipikus idejéhez képest a kölcsönhatás pillanatszerünek tekinthetö.

\subsubsection{Oseen mátrix}

A Stokes egyenletek egyik legfontosabb megoldása, amikor a tér egyetlen pontjában ható külső erő hatását vizsgáljuk. Matematikailag a pontszerű erőhatást az alábbi egyenlet írja le:

$$
\boldsymbol{f}^{e x t}(\boldsymbol{r})=\boldsymbol{f}_{0} \delta\left(\boldsymbol{r}-\boldsymbol{r}^{\prime}\right)
$$

ahol $\delta$ a Dirac delta függvény, $\boldsymbol{f}_{\boldsymbol{0}}$ a folyadékra ható erő, ami a $\boldsymbol{r}$ ' pontban hat. Ekkor a sebesség egy tetszőleges $r$ pontban az alábbi módon fejezhető ki:

$$
\boldsymbol{u}(\boldsymbol{r})=\boldsymbol{T}\left(\boldsymbol{r}-\boldsymbol{r}^{\prime}\right) \boldsymbol{f}_{0}
$$

ahol $\boldsymbol{T}$ az Oseen mátrix. Hasonlóan összefüggés írható fel a pontszerü erő hatására folyadékban fellépő nyomásra is:

$$
p(\boldsymbol{r})=\boldsymbol{g}\left(\boldsymbol{r}-\boldsymbol{r}^{\prime}\right) \boldsymbol{f}_{0}
$$

ahol $g$ a nyomás vektor.

A matematika nyelvén megnevezve az Oseen mátrix és a nyomás vektor a Stokes egyenletek Green függvénye. Mivel a Stokes egyenletek lineárisak, tetszőleges folytonos eloszlású folyadékra ható erő hatása kiszámolható a fenti függvények segítségével:

$$
\begin{aligned}
& \boldsymbol{u}(\boldsymbol{r})=\int \boldsymbol{T}\left(\boldsymbol{r}-\boldsymbol{r}^{\prime}\right) \boldsymbol{f}^{e x t}\left(\boldsymbol{r}^{\prime}\right) d \boldsymbol{r}^{\prime} \\
& p(\boldsymbol{r})=\int \boldsymbol{g}\left(\boldsymbol{r}-\boldsymbol{r}^{\prime}\right) \boldsymbol{f}^{e x t}\left(\boldsymbol{r}^{\prime}\right) d \boldsymbol{r}^{\prime}
\end{aligned}
$$

Az Oseen mátrix és a nyomás vektor a Stokes egyenletek megoldásával nyerhető a (10) egyenlettel bevezetett erő behelyettesítésével. A levezetés részletezése nélkül, ami számos könyvben megtalálható (például [21]) csak az eredményeket mutatom be:

$$
\boldsymbol{T}(\boldsymbol{r})=\frac{1}{8 \pi \eta_{0}} \frac{1}{r}\left[I+\frac{\hat{\boldsymbol{r}} \otimes \hat{\boldsymbol{r}}}{r^{2}}\right]
$$




$$
\boldsymbol{g}(\boldsymbol{r})=\frac{1}{4 \pi} \frac{\boldsymbol{r}}{r^{3}}
$$

ahol $I$ a 3x3-as az egységmátrixot, $r=|\boldsymbol{r}|, \hat{\boldsymbol{r}}=\boldsymbol{r} /|\boldsymbol{r}|$ egységvektort, $\hat{\boldsymbol{r}} \otimes \hat{\boldsymbol{r}}$ pedig diadikus szorzatot jelöl.

\subsubsection{Gömb transzlációja}

A Stokes egyenletek egyik legfontosabb megoldása, egy folyadékba merülő $a$ sugarú és $v$ sebességgel haladó gömbre ható erő meghatározását jelenti. A probléma megoldását a dolgozatomban nem részletezem, a levezetést a legtöbb hidrodinamikával foglalkozó szakkönyv tárgyalja, mint például [21].

A gömbre ható eröt a Stokes-féle súrlódási törvény adja meg:

$$
\boldsymbol{F}=\zeta^{t} \boldsymbol{v}=6 \pi \eta a v
$$

$\zeta^{t}=6 \pi \eta a$ a részecske súrlódási ellenállása.

\subsubsection{Biológiai mozgások az alacsony Reynolds számok tartományában}

Az alacsony Reynolds számok tartományán a mikroszkopikus méretü objektumok mozgását meghatározó körülmények jelentősen eltérnek a makroszkopikusan tapasztaltaktól. Egyrészt, a folyadékban kialakuló áramlási tér lamináris, nincs turbulencia. Másrészt a mozgásokat csak a viszkózus erők határozzák meg, és teljesen kizárják a tehetetlenségen alapuló úszást.

Vizsgáljuk meg, mit jelent az alacsony Reynolds számok tartománya a mikronméretű objektumok oldaláról nézve! Maga az úszás úgy jön létre, hogy egy test alakját megváltoztatva próbál előre haladni a folyadékban. A mozgás fenntartása érdekében mindig visszatér a kiindulási állapotba, megismételve a mozgást, vagyis ciklikus mozgást hajt végre. Az időben reverzibilis, vagy reciprok jellegü mozgásoknál (végrehajtunk egy mozdulatot, majd ugyanezen az úton visszatérünk az eredeti állapotba) kulcsfontosságú szerepet játszik a tehetetlenség. Ekkor ugyanis a rendszer szimmetriáját az bontja meg, ha a mozgás egyik fázisa gyorsan, míg a másik lassan játszódik le, ami lehetővé teszi a haladó mozgást. Hasonló elven úsznak például a fésűkagylók, amelyek lassan kinyitva, majd hirtelen összezárva a kagylóhéjat, és a vizet hirtelen kipréselve képesek haladni a vízben (,scallop theorem”). Azonban az alacsony Re esetén sem a tehetetlenség, sem az idő, sem 
pedig a különböző mozgásszakaszok intenzitása nem játszik szerepet az úszás folyamatában, csak a pillanatnyi alak számít. Reciprok mozgás esetén a különböző mozgásszakaszok intenzitásának változtatásával nem lehet megbontani a szimmetriát, aminek következtében egy teljes ciklusra számítva nem lesz elmozdulás a folyadékhoz képest [1, 24, 25].

Másik érdekessége a viszkózus közegben történő úszásnak, hogy az úszás hatásfoka rendkívül alacsony. Egyszerü számolással meg lehet győződni arról, hogy a sejtek mozgása során a befektetett energia a nagyrészt az őket körülvevő folyadék mozgatására (az áramlási tér kialakítására) fordul, a sejtek mozgása során a hatásfok 1-2\% körüli [1]. További érdekesség, hogy bár rendkívül alacsony a hatásfok, a mozgáshoz szükséges energiát a sejtek könnyedén képesek fedezni. Például ha $1 \mu \mathrm{m}$ sugarú gömbként kezelünk egy sejtet, ami $10 \mu \mathrm{m} / \mathrm{s}$ sebességgel mozog, akkor a teljesítményt $\left(\sim 10^{-18} \mathrm{~W}\right)$ jellemzően másodpercenként néhányszor 10 ATP molekula, illetve figyelembe véve az alacsony hatásfokot is, legfeljebb néhány 1000 ATP $\left(\sim 10^{-16} \mathrm{~W}\right)$ molekula fedezi. Ezzel szemben a sejt teljes anyagcsere folyamataiban jellemzően $10^{7}$ számú ATP $\left(\sim 10^{-13} \mathrm{~W}\right)$ molekula vesz részt másodpercenként [26].

A mikroszkopikus élőlények helyváltoztatásának alapja valamilyen időben irreverzibilis mozgás, aminek számos módja alakult ki. A baktériumok közül például azok képesek az egyik leghatékonyabb helyváltoztatásra, amelyek flagellumokkal rendelkeznek. A bakteriális flagellum merev és helikális struktúrával rendelkezik, tipikus hossza $10 \mu \mathrm{m}$, míg átmérője $\sim 10 \mathrm{~nm}$ nagyságrendjében van. Ilyen flagellumokkal úszik például az Escherichia coli. E baktérium mozgásának a vizsgálatánál megállapították, hogy az úszásnak két állapota különböztethető meg. $\mathrm{Az}$ egyik állapotot egy gyors, többnyire egyenesvonalú mozgás, míg a másik állapotot véletlenszerü bolyongás jellemez. A baktérium a mozgás két állapota között a flagellumok forgását meghajtó motorok forgásirányának megváltoztatásával tud „átkapcsolni”. Az egyenes vonalú mozgás során a sejt különböző véletlenszerü helyein eredő flagellumok köteget (bundle) alkotnak, és forgásuk szinkronizálódik. A flagellumok ellentétes irányú forgatása során a köteg szétesik, ami a mozgás megszünését is eredményezi. Ezt a fajta mozgást a szakirodalomban run-and-tumble mozgásnak nevezik [27]. 


\subsection{Szinkronizáció}

A biológiai és fizikai rendszerekben - az atomi méretektől egészen a makroszkopikus méretekig - fontos szerepet játszik a szinkronizáció. A legelső említése Christiaan Huygens nevéhez füződik. 1665-ben, amikor betegség miatt pár napig ágyba kényszerült, ugyanazon a falszakaszon lévő két ingaóra szinkronizációját figyelte meg. Később kísérletileg is megvizsgálta a jelenséget, amely kísérleti elrendezés eredeti rajzát a 1. ábra mutatja [28, 29, 30].

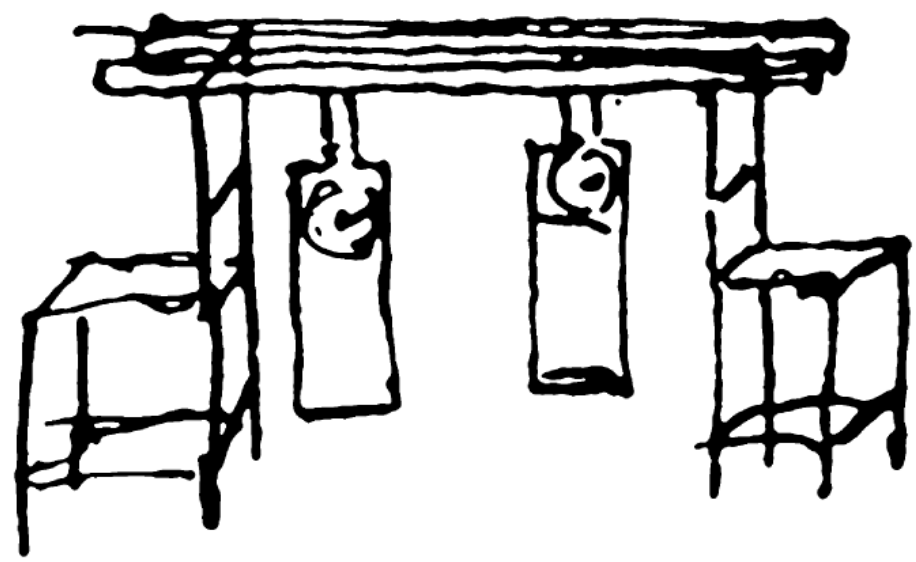

1. ábra Christiaan Huygens eredeti rajza, amiben bemutatja a kísérletét két ingaórával egy közös tartórúdon.

Rayleigh 1877-es The Theory of Sounds címü tanulmányában arról számol be, hogy amikor két orgona cső szól kis frekvenciaeltéréssel, képesek teljesen kioltani egymás hangját, vagy más esetekben pedig azonos frekvencián szólalnak meg. Ebben az esetben Rayleigh nem csak a szinkronizáció jelenségét írta le, hanem a csatolások eredményeként bekövetkező oszcillációk elhalását is.

Az élő rendszerekben lejátszódó szinkronizációról Jean-Jacques Dortous de Mairan francia csillagász és matematikus számolt be 1729-ben [31]. Kísérletében azt figyelte meg, hogy a zöldbab levele fel-le mozog a nappalok és éjszakák váltakozásának hatására. A növényt sötét szobába helyezve azt találta, hogy a levelek mozgása megmarad a fényviszonyok változása nélkül is, azonban ekkor a periódus nem pontosan 24 óra. Azóta hasonló kísérletet számos rendszeren végeztek, hasonló eredménnyel. Régóta ismert tény tehát, hogy a biológiai rendszereknek saját 
biológiai órájuk van, és ez alapesetben a napszakok változásához szinkronizálódik, de elszigetelt környezetben eltérhet a 24 órás ciklustól [28]. E cirkadián órák müködésével kapcsolatos munkáért adták 2017-ben az orvosi Nobel-díjat.

\subsubsection{Mi a szinkronizáció?}

A szinkronizáció jelenségét a [28] mü alapján ismertetem. Az előzőekben néhány példát soroltam fel a szinkronizációs jelenségek megismerésének korai időszakából. De pontosan mit is jelent a szinkronizáció? A szinkronizáció: oszcilláló objektumok frekvenciájának/ütemének/ritmusának összehangolódása a közöttük fellépő gyenge kölcsönhatás következtében. A szikronizáció kvalitatív megértéséhez az alábbi kérdések megválaszolása szükséges:

1. Mi oszcillál/mi az oszcillátor?

2. Mi a frekvencia, vagy ritmus?

3. Mi a kölcsönhatás?

4. Hogyan változik meg a frekvencia?

1. Mi az oszcillátor?

Az oszcillátor egy olyan aktív rendszer, amelynek belső energiaforrása van, amit oszcillációs mozgássá alakít át (autonóm müködésü oszcillátor). Az oszcilláció akkor is megmarad, ha a kölcsönható rendszereket eltávolítjuk egymástól. Az oszcilláció egészen addig fennmarad, amíg a müködéshez szükséges energia rendelkezésre áll. Az oszcillációt kizárólag a rendszer paraméterei határozzák meg. Perturbációkkal és tranziens hatásokkal szemben úgy viselkedik, hogy idővel ezek hatása elhal és csak a saját oszcillációi lesznek dominánsok.

2. Mi a frekvencia/ritmus?

Az önműködő oszcillátorok müködése igen eltérő lehet: működhet egy egyszerü szinuszos hullám szerint, vagy akár rövid impulzusok sorozata szerint is. Az oszcilláció jellemzésére a frekvenciát, vagy periódusidőt használják. Az izolált rendszer frekvenciája a saját vagy természetes frekvencia.

3. Mi a kölcsönhatás?

A két oszcillátornak valamilyen módon kölcsön kell hatni egymással. Egyrészt a kölcsönhatás lehet rendkívül gyenge, például, Huygens kísérletében az ugyanazon a rúdon (azonos falrészen) felfüggesztett két ingaóra esetén a csatolást a rúd (azonos falrész) rugalmassága biztosította, és a szinkronizáció a rúd vibrációi által valósult meg. Másrészt túl erős kölcsönhatás lehetetlenné teszi 
a szinkronizáció kialakulását, például ha a fenti kísérletben a két ingát egy merev rúddal összekötjük, akkor együtt fognak rezegni, viszont maga a jelenség már nem szinkronizáció. Itt meg kell jegyezni, hogy nem magát az állapotot nevezzük szinkronizációnak, hanem azt az összetett folyamatot, ami az állapot kialakulását eredményezi. Fontos kérdés, hogy hol van a határ az erős és gyenge kölcsönhatás között, amely egyik esetben szinkronizációhoz, másik esetben egy új, egyesített rendszerhez vezet. A két tartomány különválasztására nincsenek szigorú szabályok és definíciók, durván megfogalmazva: a kölcsönhatás következtében az egyik rendszer ne befolyásolja olyan mértékben a másikat, hogy az a viselkedését (különösen a saját oszcillációjának ritmusát) kvalitatív módon megváltoztassa.

4. Hogyan változik meg a frekvencia?

Általában két oszcillátor nem rendelkezik ugyanazzal a frekvenciával. Az oszcillátorok sajátfrekvenciájának különbségét a $\Delta f=f_{1}-f_{2}$ mennyiség jellemzi, ahol $f_{1}$ és $f_{2}$ az izolált oszcillátorok sajátfrekvenciája. A csatolás következtében frekvenciájuk megváltozik, és egy új $F_{1}$ és $F_{2}$ frekvenciával (vagy $\Delta F=F_{1}-F_{2}$ frekvenciakülönbséggel) fognak oszcillálni adott $\Delta f$ sajátfrekvencia-különbség esetén. A csatolt oszcillátorok frekvenciájának tipikus viselkedése figyelhető meg a 2. ábrán a sajátfrekvencia-különbségek függvényében.

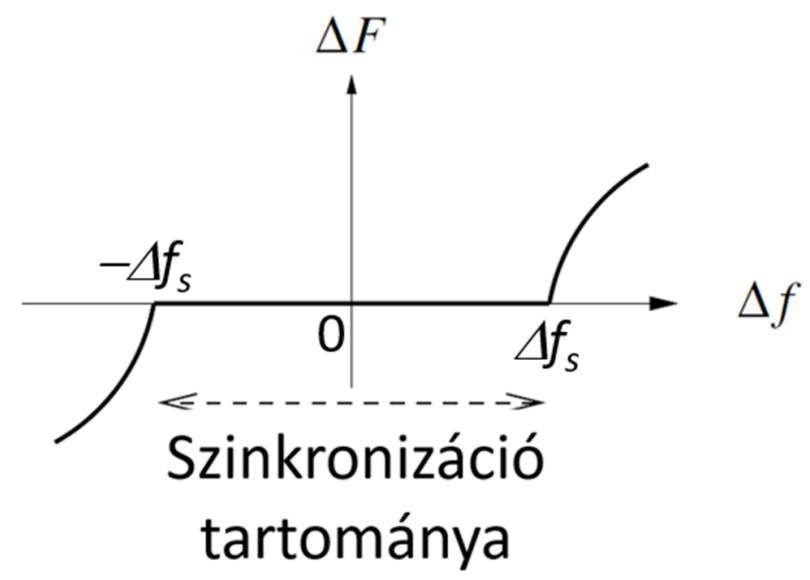

2. ábra Az oszcillátorok frekvenciájának elhangolódása a sajátfrekvenciák különbségének függvényében. 
Megfigyelhető, hogy kis frekvenciakülönbségek esetén ugyanazzal a frekvenciával oszcillálnak, ez a szinkronizált állapot. A maximális $\Delta f_{s}$ mennyiség, ahol még szinkronizáció történik, a csatolás erősségének növekedésével általában növekszik.

A szinkronizáció kialakulása során az oszcillátorok azonos frekvenciával kezdenek müködni, ez különböző fázisviszonyok között tud megvalósulni. Eszerint meg lehet különböztetni az in-phase állapotot, amikor a fázisok megegyeznek és anti-phase állapotokat, amikor ellentétes fázisban vannak, illetve előfordulhat az az eset is, amikor a sebességek megegyeznek, de egy tetszőleges fázisú állapotban csatolódnak, ez a fáziscsatolt állapot (phase locked) állapot. Mivel a szakirodalomban a terminológiák használata nem egységes, emiatt szükséges rögzíteni, hogy a dolgozatomban nem különböztetem meg a szinkronizáció különböző típusait.

\subsubsection{Szinkronizáció a mikrotartományban}

A fenti példák alapján látható, hogy már rendkívül gyenge kölcsönhatás is elegendő a szinkronizáció megjelenéséhez, így természetes módon elvárható lenne a fellépése a mikroszkópikus mérettartományban, ahol a hidrodinamikai kölcsönhatás akár erős csatolást jelenthet. Számos megfigyelés támasztja alá, hogy a szinkronizáció fontos szerepet játszik a „mikroúszók” mozgásában, mint például a protozoák [32], algák [4], spermatozoák [33] helyváltoztatása során, amelyek flagellumok vagy csillók szinkronizált mozgásának segítségével hajtják meg magukat. A Chlamydomonas zöldalga két flagelluma segítségével hasonlóan úszik, mint az ember mellúszása, és a flagellumok szinkronizált mozgása kritikus az egyenes vonalú haladás szempontjából [4]. Mivel a szinkronizáció gyakorlatilag mindenütt előfordul az élő szervezetekben/rendszerekben, a mikroszkopikus élölények mozgásának megértése szempontjából kulcsfontosságú a hidrodinamika és a szinkronizáció kapcsolatának megértése.

A szinkronizáció jelenségét a mikrobiológiában már az 1920-as években megfigyelték, ahogy azt Gray 1928-as Ciliary movement címü könyvében említi [34]. A 3. ábrán látható, hogy Gray megfigyelése szerint milyen aggregátumok alakulhatnak ki a Spirochaeta balbiani sejtek együttes mozgása során. 

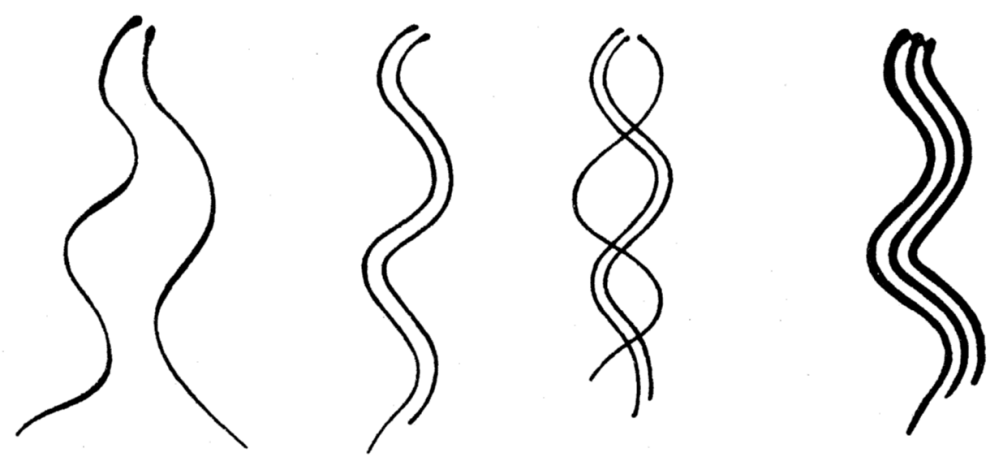

3. ábra A Spirochaeta balbiani baktériumok által formált aggregátumok, ahol az egyedek mozgása szinkronizált [34].

Először Taylor vetette fel úttörő jelentőségű munkájában, 1951-ben, hogy a hidrodinamikai kölcsönhatásnak szerepe lehet a mikroméretek tartományában kialakuló szinkronizációban [35]. Megmutatta, hogy sokkal kevesebb energia nyelődik el a környező folyadékban, ha két egymáshoz közel úszó lemez hullámzása azonos fázisban van, illetve fáziseltérés esetén olyan hatások lépnek fel, amelyek az eltéréseket kiegyenlítik.

A csillók szinkronizált mozgását, illetve sok csilló esetén a szinkronizáció révén létrejövő kvázi haladó hullám („metachronal wave” - e jelenség makroszkopikus megvalósulása a stadionok mexikói hulláma) kialakulásának okát a 90-es évekig nem vizsgálták részletesen. Kezdetben spekulatív utalásokat közöltek, amelyekben a csillók szinkronizált mozgását a hidrodinamikai kölcsönhatással hozták összefüggésbe [36, 37, 38]. A '90-es években Gueron és Liron bevezettek egy numerikus modellt, amely képes volt leírni két csilló hidrodinamikai kölcsönhatás következményeként lejátszódó szinkronizálódását, illetve sok csilló esetén a metachronal wave kialakulását [39, 40, 41]. Számos modellben a csillók viselkedését energetikai oldalról is vizsgálták és arról számoltak be, hogy kedvezőbb a szinkronizált állapot, amely segítségével például nagyobb „,csapkodási” frekvencia érhető el, és a csillók által meghajtott áramlási tér sebessége (vagy a „mikroúszó” sebessége a folyadékhoz képest) is nagyobb [42, 43, 44].

A flagellumok szinkronizációjának első részletesebb matematikai vizsgálatát Machin végezte el, ahol a flagellumot rugalmas rúdként kezelte. Számolásainak eredményeként azt kapta, hogy egy flagellum saját oszcillációit egy másik flagellum oszcillációi képesek elnyomni a hidrodinamikai kölcsönhatás által, aminek következtében a másik flagellum frekvenciáján kezd oszcillálni [45, 
46]. Coakley energetikai oldalról vizsgálta a szinkronizált flagellumokat és megmutatta, hogy szinkronizáltan forgó flagellumok esetén jelentős a disszipáció csökkenés [47].

Amint már említettem, néhány korai kísérleti megfigyelés már utalt arra, hogy a hidrodinamikai kölcsönhatásnak szerepe lehet a szinkronizációban, ezeket Howard Berg kritikusan tárgyalta [48]. Például a közeg viszkozitásának kismértékü növelésével a baktériumok mozgása rendezettebbé és gyorsabbá válik [49, 50], ami jól magyarázható azzal, hogy több flagellum áll össze kötegekké [51], illetve az egymáshoz közel úszó spermatozoa sejtek flagellumai szinkronizálódnak [35].

A hidrodinamikai hasonlóság elvét kihasználva kialakították a mikroszkopikus rendszerek makroszkopikus modelljét, és a modellrendszerben a szinkronizáció lejátszódását demonstrálták $[52,53,54]$. Ezekben a kísérletekben megállapították, hogy a szinkronizálódás lejátszódhat tisztán a hidrodinamika által hajtott folyamatként.

Goldstein és mtsai a Chlamydomonas reinhardtii (CR) két-flagellumos sejtek mozgását figyelték meg 3 dimenziós videomikroszkópiával, illetve a mozgás és a flagellumok szinkronizálódásának kapcsolatát vizsgálták. A CR sejtek helyváltoztatása során a két flagellum mozgása szinkronizálódik, míg irányváltoztatások során a szinkronizáció megbomlik. A sejtek a két állapot közötti kapcsolást a flagellumok csapkodási frekvenciája különbségének változtatásával tudják elérni, ugyanis már kicsit eltérő frekvenciák esetén is megszünik a szinkronizáció $[4,55]$. Goldstein és mtsai ezt követő munkájukban eltávolították a CR flagellumait, majd az újonnan kinövő flagellumok hosszának függvényében vizsgálták a szinkronizáció erősségét. Azt kapták, hogy a flagellumok hosszával lineárisan növekedett a szinkronizáció erössége, amivel kísérletileg bizonyítottnak látták, hogy a hidrodinamikai kölcsönhatásnak jelentős szerep jut a flagellumok szinkronizációjának kialakulásában [56]. Újabban viszont olyan elmélet is született a CR flagellumok szinkronizációjára, amely szerint a csatolást a rugalmas sejtfal biztosítja [57] - látszik tehát, hogy a jelenség magyarázata korántsem egyszerü.

Bár számos kísérleti bizonyíték van arra, hogy a hidrodinamikai kölcsönhatás kulcsfontosságú szerepet játszhat a szinkronizáció kialakításában, ezek a megfigyelések vagy makroszkopikus rendszerben, vagy in vivo körülmények között történtek. Egy makroszkopikus rendszerben a zajnak nem jut jelentős szerep, ezzel szemben a zaj a mikroszkopikus tartományban igen jelentősen befolyásolja a folyamatokat, hatása általában a fellépő erőkkel azonos nagyságrendű. $\mathrm{Az}$ in vivo kísérletek hátránya, hogy nehezen ellenőrizhető, illetve körülményesen, és csak kismértékben módosítható a rendszer. Ez inspirálta a kutatókat, hogy mesterséges struktúrákat 
alkalmazva végezzenek el kísérleteket a mikroszkopikus mérettartományban. Az első ilyen kísérletekben optikai csipesz segítségével különböző távolságban tartott [58], illetve az optikai csipesz segítségével oszcilláltatott gömb alakú részecskék kölcsönhatását vizsgálták [59]. Minden kísérletben sikerült a hidrodinamikai szinkronizáció kialakulását demonstrálni. Ezekben a kísérletekben transzlációt végző részecskék szinkronizációját vizsgálták.

Az általam elvégzett kísérlet volt az első, amelyben a mikroszkopikus tartományban ellenőrizhető körülmények között mesterségesen elöállított forgó oszcillátorok (forgó rotorok) segítségével demonstráltam a szinkronizáció megjelenését [T3]. Optikai csipesszel meghajtott mikrorotorok segítségével megmutattam, hogy a mikroszkopikus tartományban forgó struktúrák között kizárólag a hidrodinamikai kölcsönhatás közvetítésével kialakulhat a szinkronizáció. Kísérleteimet követően mások is hasonló eredményre jutottak csapdázott ellipszoidok [3], vagy körpályára kényszerített kolloid részecskék [60] kölcsönhatásának vizsgálatával.

Lényeges különbség a transzlációt és rotációt végző rendszerek között, hogy míg a transzlációs mozgások szinkronizációja akár még $40 \mu \mathrm{m}$-es távolságban is lejátszódhat [58], addig a forgó mozgások szinkronizációja néhány $\mu \mathrm{m}$ után a termális fluktuációk következtében már nem mutatható ki [T3].

\subsubsection{Szinkronizáció feltétele}

A viszkózus közegben kialakuló szinkronizáció feltételeit elméleti oldalról számos alkalommal vizsgálták. Kim és Powers numerikus modelljükben két rögzített tengellyel forgó hélix között ható hidrodinamikai kölcsönhatást vizsgálták az alacsony Reynolds számok tartományban és azt tapasztalták, hogy nem lép fel a szinkronizáció [61]. Hasonló számítást végzett el Reichert és Stark, azonban a modelljükben a hélixek tengelye már nem volt rögzített. Ekkor megjelent a hidrodinamikai szinkronizáció, ami alapján arra a következtetésre jutottak, hogy szükség van az oszcilláló rendszer bizonyos fokú flexibilitására [62]. Lenz és munkatársai rögzített, körpályán mozgó gömbalakú részecskékkel modellezték a csillók mozgását, és a modellben nem játszódott le a szinkronizáció [63]. Hasonló fix pályán mozgó részecske modellt alkalmazott Vilfan, azonban a trajektóriák egymáshoz viszonyított dőlésszögét változtatta, és mind azonos fázisú, mind ellentétes fázisú szinkronizáció megjelent [64]. Uchida és munkatársai modelljükben azt mutatták meg, hogy aszimmetrikus és fix pályák esetén is meg tud jelenni szinkronizáció, amennyiben a mozgást meghajtó erőt nem tartják rögzítetten, hanem fázisfüggő erőket vezetnek be $[65,66]$. 
Niedermayer és munkatársai szintén hasonló eredményre jutottak, mikor analitikusan és numerikusan is megvizsgálták két, illetve több csilló szinkronizációját az alacsony Reynolds számok tartományán, amiben csillók szinkronizációját modellezték körpályán mozgó mikrogömbök segítségével. Azt kapták, hogy a szinkronizáció kialakulásában kulcsfontosságú egy további szabadsági fok bevezetése, mégpedig, hogy a gömbök pályája rugalmas legyen [67]. Niedermayer munkáját azért érdemes kiemelni, mert a szinkronizáció bonyolult nem-lineáris problémájára zárt alakban találtak analitikus megoldást, ezt a következő fejezetben részletesebben be fogom mutatni.

\subsubsection{A hidrodinamikai szinkronizáció egyszerü modellje}

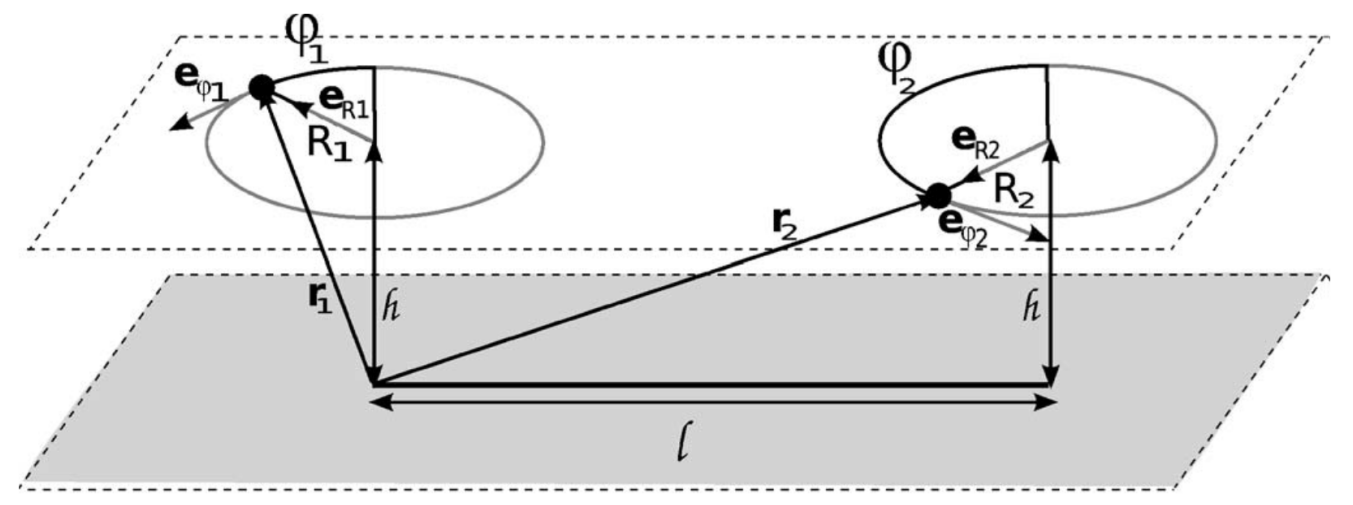

4. ábra A hidrodinamikai szinkronizáció legegyszerübb modellje

Niedermayer gondolatmenetét [67] követve vizsgáljuk meg, hogyan szinkronizálódik két mikrogyöngy a 4. ábrán látható elrendezésben - azaz két egymás mellett, körpályán, azonos síkban és azonos irányba mozogva - a hidrodinamikai kölcsönhatás eredményeként. Az eredeti elgondolás szerint Niedermayer csillók szinkronizációját vizsgálta, amiket bizonyos egyszerüsítések bevezetése után mikrogyöngyökkel helyettesített. Most ezektől az egyszerüsítésektől eltekintünk, és kiindulásként tekintsünk mikrogyöngyöket! A levezetésben figyelembe van véve, hogy csillók a lipidmembránhoz rögzülnek, ezt a jelen levezetésben is figyelembe veszem. Ennek megfelelően a gömbök sugarát jelölje $a$, míg a membrántól való távolságot $h$. Az egyes gömbök zárt trajektórián, mégpedig egy $R_{0}$ sugarú körpályán mozognak, miközben $h$ állandó marad. A körpálya sugarában némi flexibilitás megengedett, azaz a körpálya 
síkjában le tudnak térni a körpályáról, de ekkor egy visszatérítő erő hat, ami a megadott körpályán igyekszik tartani a gömböket: $F_{r}=\boldsymbol{F}_{\boldsymbol{r}} \boldsymbol{e}_{r}=-\lambda\left(R-R_{0}\right)$. A $\lambda$ rugóállandó a csilló hajlítási rugalmasságától függő paraméter, és értéke tipikusan $\lambda=10^{-5}-10^{-4} \mathrm{~N} / \mathrm{m}$. A gömbök mozgását meghajtó $\boldsymbol{F}_{\text {in }}$ erőt előírjuk, és nem a molekuláris folyamatokból származtatjuk.

\subsubsection{Egyetlen mikrogyöngy mozgása}

Elöször tekintsük egyetlen mikrogyöngy mozgását! Mivel a mikrogyöngyök mozgása teljesen túlcsillapított, a gömbre ható erők, tehát a közegellenállás $\boldsymbol{F}_{d}$, a meghajtó $\boldsymbol{F}_{\text {in }}$ és visszatérítő erők $\boldsymbol{F}_{r}$ egyensúlyban vannak:

$$
\boldsymbol{F}_{d}+\boldsymbol{F}_{i n}+\boldsymbol{F}_{r}=0
$$

Alacsony Reynolds tartományban a Stokes-törvény fejezi ki a közegellenállást, ami egy gömb alakú objektumra hat:

$$
\boldsymbol{F}_{d}=-6 \pi \eta a \boldsymbol{u}=-\zeta \boldsymbol{u}
$$

ahol $\boldsymbol{u}$ a gömbnek a folyadékhoz viszonyított sebessége, míg $\zeta=6 \pi \eta a$ a súrlódási ellenállás. Mivel az $\boldsymbol{F}_{\text {in }}$ (mindig érintő irányba mutat) és $\boldsymbol{F}_{r}$ (mindig sugárirányú) merölegesek egymásra, polár koordinátákban a mozgásegyenlet az alábbi alakot ölti:

$$
\begin{gathered}
\zeta R \dot{\varphi}=F_{\text {in }} \\
\zeta \dot{R}=-\lambda\left(R-R_{0}\right)
\end{gathered}
$$

Mivel $a$ jellemzően $0.1 \mu \mathrm{m}$ és néhány $1 \mu \mathrm{m}$ közötti tartományban változik, a $\lambda / \zeta \approx 100-1000 \mathrm{l} / \mathrm{s}$, tehát a radiális irányú dinamika sokkal gyorsabb, mint érintőleges irányban, ez úgy összegezhető, hogy a mikrogyöngy állandó $\omega$ szögsebességgel mozog egy köralakú pályán:

$$
\begin{gathered}
\dot{\varphi}=\frac{F_{\text {in }}}{\zeta R_{0}}=\omega \\
R=R_{0}
\end{gathered}
$$

Ebből a meghajtóerő kifejezhető, mégpedig $F_{\text {in }}=\zeta R_{0} \omega$. Mint ahogy azt majd látni fogjuk, a fenti egyszerü modell elegendően komplex ahhoz, hogy mikrogyöngyök együttes mozgásának vizsgálata a szinkronizáció megjelenéséhez vezessen. 


\subsubsection{Két mikrogyöngy csatolt mozgása}

Két csatolás nélküli mikrogyöngy mozgását a (20) és (21) egyenletek írják le. Azonban egy másik mikrogyöngy jelenléte a sebességmezőt módosítja, minek következtében az egyenletek az alábbi formát öltik:

$$
\begin{gathered}
\zeta R\left(\dot{\varphi}-\boldsymbol{e}_{\varphi_{1}} \cdot \boldsymbol{v}_{12}\right)=F_{i n}=\zeta R_{0} \omega_{1} \\
\zeta\left(\dot{R}-\boldsymbol{e}_{R_{1}} \cdot \boldsymbol{v}_{12}\right)=-\lambda\left(R-R_{0}\right)
\end{gathered}
$$

Ahol $\boldsymbol{v}_{12}$ jelöli a folyadékban kialakuló sebesség mezőt, amit a 2-es mikrogyöngy az 1 -es helyén létrehoz. Az $\boldsymbol{e}_{R 1}$ és $\boldsymbol{e}_{\phi 1}$ a radiális és érintő irányba mutató egységvektorok. Az 1 és 2-es mikrogyöngy pozíciója az alábbi formában adható meg:

$$
r_{i}(t)=\left[-R_{i}(t) \sin \left(\varphi_{i}(t)\right)+(i-1) l \quad R_{i}(t) \cos \left(\varphi_{i}(t)\right) \quad h\right]
$$

$i=1$ vagy 2 annak megfelelöen, hogy az egyik vagy másik mikrogyöngyöt jelöli, $l$ a mikrogyöngyök pályájának középpontja közötti távolság.

Amennyiben a falak mentén a csúszásmentes peremfeltételt nem vesszük figyelembe (nincs fal), akkor:

$$
\boldsymbol{v}_{12}=\frac{\boldsymbol{s}+\boldsymbol{n}_{12}\left(\boldsymbol{s} \cdot \boldsymbol{n}_{12}\right)}{\left|\boldsymbol{r}_{12}\right|}+o\left(\left(\frac{a}{r_{12}}\right)^{3} s\right)
$$

ahol $\boldsymbol{n}_{12}=\boldsymbol{r}_{12} /\left|\boldsymbol{r}_{12}\right|$ és $\boldsymbol{r}_{12}$ a 2-es mikrogyöngytől az 1 -es felé mutató vektor, $\boldsymbol{s}$ értékét a 2-es mikrogyöngy sebessége határozza meg:

$$
\boldsymbol{s}=\frac{3 a}{4} \dot{\boldsymbol{r}}_{2}=\frac{3 a}{4}\left(R_{2} \dot{\varphi}_{2} \boldsymbol{e}_{\varphi_{2}}+\dot{R}_{2} \boldsymbol{e}_{R_{2}}\right) \approx \frac{3 a}{4} R_{2} \dot{\varphi}_{2} \boldsymbol{e}_{\varphi_{2}}
$$

A csúszásmentes peremfeltételt figyelembe véve:

$$
\boldsymbol{v}_{12}=12 h^{2} \frac{\boldsymbol{n}_{12}\left(\boldsymbol{s} \cdot \boldsymbol{n}_{12}\right)}{\left|\boldsymbol{r}_{12}\right|^{3}}+o\left(a^{3} h^{2} s / r_{12}^{5}\right)
$$

Megmutatható, hogy $R<<$ esetén a mikrogyöngyök mozgását az alábbi csatolt differenciálegyenletrendszer írja le:

$$
\begin{aligned}
& \dot{\varphi}_{1}=\omega_{1}-\rho \omega_{2} J\left(\varphi_{1}, \varphi_{2}\right)-\rho \alpha \omega_{1} \omega_{2} K\left(\varphi_{1}, \varphi_{2}\right) \\
& \dot{\varphi}_{2}=\omega_{2}-\rho \omega_{1} J\left(\varphi_{2}, \varphi_{1}\right)-\rho \alpha \omega_{1} \omega_{2} K\left(\varphi_{2}, \varphi_{1}\right)
\end{aligned}
$$


ahol $\rho \equiv \frac{1}{2 l} \frac{3 a}{4}\left(\frac{\sqrt{12} h}{l}\right)^{v}, \alpha \equiv \varpi \frac{\zeta}{\lambda}$ és $\varpi \equiv \sqrt{\omega_{1} \cdot \omega_{2}}$.

A kölcsönhatást a $J$ és $K$ függvények írják le az alábbi módon:

$$
\begin{gathered}
J\left(\varphi_{i}, \varphi_{j}\right) \equiv-\mu \cos \left(\varphi_{i}-\varphi_{j}\right)-\cos \left(\varphi_{i}+\varphi_{j}\right) \\
K\left(\varphi_{i}, \varphi_{j}\right) \equiv-\mu \sin \left(\varphi_{i}-\varphi_{j}\right)+\sin \left(\varphi_{i}+\varphi_{j}\right)
\end{gathered}
$$

A $\mu$ és $v$ paraméterek értékét a peremfeltétel szabja meg, azaz, ha a membrán jelenlétét nem vesszük figyelembe $(\mu, v)=(3,0)$, illetve ha figyelembe vesszük, akkor $(\mu, v)=(1,2)$. Amennyiben $\alpha=0$, akkor $R_{i}=R_{0}$, azaz radiális irányban a mozgásnak nincs flexibilitása. Ekkor szinkronizáció nem jelenik meg. Az $\alpha \neq 0$ feltétel már elegendő a szinkronizáció megjelenéséhez. A továbbiakban a szinkronizáció vizsgálata céljából érdemes bevezetni a két mikrogyöngy fázisának a különbségét $\chi=\varphi_{1}-\varphi_{2}$, illetve a fáziskülönbség időbeli változását, ami a (30) és (31) egyenlet alapján:

$$
\dot{\chi}=\left(\omega_{1}-\omega_{2}\right)\left(1+\rho J\left(\varphi_{1}, \varphi_{2}\right)\right)-\gamma \sin \chi
$$

ahol $\gamma=2 \mu \alpha \rho \omega_{1} \omega_{2}>0$.

$\omega_{1}=\omega_{2}$ eset

Abban az esetben, amikor a mikrogyöngyök mozgását meghatározó szögsebesség megegyezik, a fáziskülönbség változása explicit módon is megadható:

$$
\chi(t)=2 \arctan \left(\tan \left(\frac{\chi_{0}}{2}\right) \cdot e^{-\gamma t}\right)
$$

Két egyensúlyi helyzete van a mikrogyöngyöknek: egy instabil $\chi_{i}=\pi$, illetve egy stabil $\chi_{s}=0$. Egy tetszőleges $\chi_{0}$ szögröl indulva a $\chi_{s}=0$ pozícióban fog szinkronizálódni a mikrogyöngyök mozgása. Az is látható, hogy a mikrogyöngyök szinkronizációjához szükséges idő $\gamma$-val fordítottan arányosan növekszik. 
$\omega_{1} \neq \omega_{2}$ eset

Eltérő frekvenciák (feltételezve, hogy $\rho$ illetve a frekvenciák különbsége $\Delta \omega=\omega_{1}-\omega_{2}$ elég kicsi) esetén a (34) egyenlet az alábbi alakot ölti:

$$
\dot{\chi}=\Delta \omega-\gamma \sin \chi
$$

Stacionárius megoldás akkor létezik, ha $|\Delta \omega| \leq \gamma$. A $\gamma_{c}=|\Delta \omega|$ az a kritikus érték, amelynél még a fáziscsatolás lejátszódik. Ekkor az egyensúlyi helyzetet:

$$
\chi_{S}=\arcsin \frac{\Delta \omega}{\gamma}
$$

Tehát, ha a frekvenciák eltérőek, akkor a mikro gyöngyök mozgása fáziscsatolt lesz, de nem szinkronizált. A fáziskapcsoláshoz szükséges idő a $\gamma$ csökkenésével növekszik, és $\gamma_{c}$ értékénél a végtelenbe tart. Amennyiben a frekvenciák közelítenek egymáshoz, akkor $\gamma_{c} \rightarrow 0$, ami azt a jelentést is hordozza, hogy nagyon gyenge kölcsönhatás is elegendő a fáziscsatolt állapot beállásához, bár az ehhez szükséges idő alacsony $\gamma$ esetén jelentősen megnő. 


\subsection{Optikai manipuláció}

\subsubsection{Az optikai manipuláció történeti áttekintése}

Már Kepler felvetette, hogy a fény képes erőhatás kifejtésére, amint 1619-ben a De Cometis-ben az üstökösök csóvájának napsugarak általi eltérüléséröl ír [68]. A 19. század végén Maxwell elektromágneses elmélete pontosan megadta, hogy a fény impulzusa arányos az intenzitással. Egy testet megvilágítva a fény az impulzusát képes egy objektumnak átadni, azaz a sugárzási nyomás a fény terjedésének irányába löki a testet [69].

A fénynyomás hatásának első kísérleti demonstrálása makroszkopikus testeken 1901-ben történt Lebegyev [70], illetve Nichols és Hull által [71, 72], ezzel igazolva Maxwell elméletét. Ezt követően számos hasonló kísérletet végeztek el, de ezek leginkább csak látványosak és érdekesek voltak, a gyakorlati alkalmazás szempontjából nem volt jelentőségük. A lézerek 1960-as megjelenése azonban jelentős fellendülést hozott ezen a területen.

1970-ben Ashkin megmutatta, hogy egy fókuszált lézer nyaláb sugárnyomása jelentősen képes befolyásolni egy mikronméretű semleges részecske dinamikáját [73]. Két alapvető fénynyomásból eredő erőt azonosított: az egyik a megvilágítás tengelyében ható és a szóródástól származó erő, a másik az intenzitásgradienstől származó gradienserő, ami a gradiens irányába hat. Azt is megmutatta, hogy csupán ezen erők alkalmazásával a részecske gyorsítható, lassítható, vagy akár stabilan 3 dimenzióban csapdázható (optikai csipesz).

Forradalminak számított az az elképzelés, hogy egyedi részecskék külön-külön vizsgálhatók. Az új csapdázási eljárást a rákövetkező években széleskörüen alkalmazták a fizika és kémia tudományterületein különböző atomok, molekulák eltérítésére, hűtésére, vagy stabil csapdázására $[74,75,76]$. Az atomfizikában az egyik legjelentősebb eredmény, hogy az atomok csapdázásával és hűtésével kísérletileg is megvalósították a Bose Einstein kondenzációt [77].

Az 1980-as években az optikai csapdázás első biológiai alkalmazására is sor került [78], és az eljárás a sejtek mechanikai kapcsolat nélküli manipulációjára is alkalmasnak bizonyult. Azóta igen széleskörúen alkalmazzák a biológiában és nem csak sejtek, de sejtalkotók, fehérjék csapdázására is. Az optikai csipesz a femto és piko Newton nagyságrendű erők mérését is lehetővé teszi. Mivel a sejtekkel kapcsolatos folyamatokban hasonló nagyságrendű erők lépnek fel, igen hasznos 
eszköznek bizonyult a biológiában a mikromechanikai, elasztikus és dinamikai tulajdonságok meghatározására, melyek közül néhány példa a bakteriális flagellumok torziós rugalmassága [79], izolált vörös vérsejt váz rugalmas tulajdonságai [80]. Ezen túl, a biológiai motorok is ilyen erők kifejtésére képesek, vagyis ezeket is kiválóan lehet lézercsipesszel vizsgálni, pl. néhány dienin motor által kifejtett erő meghatározása [81], egyetlen kinezin molekula mozgásának részletei [82, 83, 84], egyetlen RNS polimeráz enzim által kifejtett erő [85].

Az ezredfordulót követően számos kutatás irányult az optikai csapda „tökéletesítésére”, illetve a csapda tulajdonságainak manipulálására, e fejlesztések fontos eredménye a holografikus optikai csipesz. Egy holografikus optikai csipeszben a csapdát létrehozó lézernyaláb amplitúdójának vagy fázisának befolyásolásával, amit általában térbeli fénymodulátorral (SLM) végeznek, a korábbi egy-két csapda helyett nagy számú (akár 10-100) optikai csapda hozható létre a mintatérben, amelyek egymástól függetlenül vezérelhetők [86, 87, 88, 89]. A holografikus vezérlés további nagy előnye, hogy a fázisfront befolyásolásával a csapdázó nyaláb módusát is meg lehet változtatni, így például Bessel, vagy Laguerre-Gauss nyaláb is előállítható, amivel a lehetséges alkalmazások köre tovább bővült [90, 91, 92, 93]. A nyaláb manipulációban fontos elörelépés volt az SLM-en alapuló fázisfront korrekció, amely segítségével a szférikus aberrációt lehet kiküszöbölni [94, 95, 96], lévén ez az optikai csapdázás hatásfokának egyik leggyakoribb limitáló tényezője. A fázisfront korrekciót ki lehet terjeszteni akár az egész optikai rendszerre, tehát az egész optikai rendszerben fellépő fázisfront torzulásokat ki lehet küszöbölni, amivel „tökéletes” optikai csapda állítható elő. Az optimalizáció azt is eredményezi, hogy rendkívül alacsony intenzitás mellett is képes csapdázni, tovább kiterjesztve a roncsolásmentes csapdázás lehetőségét [97].

A több nyaláb együttes alkalmazása lehetővé teszi nagyméretü, bonyolult alakú, akár mindhárom dimenzióban kiterjedt struktúrák csapdázását is. Az utóbbi években az optikai csapdázás mikrorobotikai alkalmazása, azaz komplex mikrostruktúrák, mikroszerkezetek direkt és indirekt manipulációja is elterjedőben van $[98,99,100]$. 


\subsubsection{Az optikai manipuláció elméleti háttere}

Az optikai mikromanipuláció során közvetlenül használjuk ki azt a tényt, hogy az elektromágneses hullámokhoz impulzus rendelhető. A hullám impulzussürüségét - amely a Maxwell egyenletekből levezethető - a Planck-féle reláció adja meg:

$$
g=\frac{1}{c^{2}} \boldsymbol{S}=\frac{1}{c^{2}}(\boldsymbol{E} \times \boldsymbol{H})
$$

ahol $c$ a fénysebesség vákuumban, $\boldsymbol{S}$ a Poynting vektor, $\boldsymbol{E}$ az elektromos tér vektor, $\boldsymbol{H}$ a mágneses térerősség vektor. Ha a hullámfront teljes felületére integráljuk a fenti mennyiséget, akkor a hullám teljes impulzusát kapjuk meg, ami a hullám szabad terjedése során állandó mennyiség. Amikor a hullám anyaggal találkozik, megtörik, visszaverődik, elnyelődik, szóródik, stb... aminek következtében az impulzusa megváltozik. Ennek az impulzusváltozásnak megfelelő nagyságú, de ellentétes irányú impulzusváltozást szenved el az anyag a kölcsönhatás során. Bár a háttérben meghúzódó fizikai elv egyszerü, a kölcsönhatás pontos modellezése, illetve az optikai csipeszben fellépő erők és nyomatékok kiszámolása általában körülményes feladat. A probléma bonyolultságát nagymértékben meghatározza a struktúra mérete és alakja is.

Ha a struktúra mérete sokkal nagyobb a fény hullámhosszánál, akkor jól használható a geometriai optika [101, 102, 103, 104]. Legelőször Ashkin számolta ki az erősen fókuszált fénynyaláb által mikronméretü dielektrikum gömbre ható erőket [101]. A geometriai optikai közelítés alkalmazhatóságát jól mutatja az 5. ábra, ahol egy R sugarú, vízben lévő dielektrikum gömb (n=1.52) 632 nm hullámhosszú és 1.2 numerikus apertúrájú Gauss nyalábbal történő megvilágítása esetén a csapdaerősség geometriai és a hullámoptika alapján becsült értékének összehasonlítása látható a gömb átméröjének függvényében. $\mathrm{R} \gg>\lambda$ esetén a geometriai optikai közelítés nagyon jó egyezésben van a hullámoptikai közelítéssel [105].

Amennyiben a struktúra mérete sokkal kisebb a fény hullámhosszánál $(<\lambda / 20$, Rayleigh tartomány), az erők számolása egyetlen dipólusra ható Lorentz erő számolásán alapul, ahogy azt Yasuhiro mutatta meg [106]. 


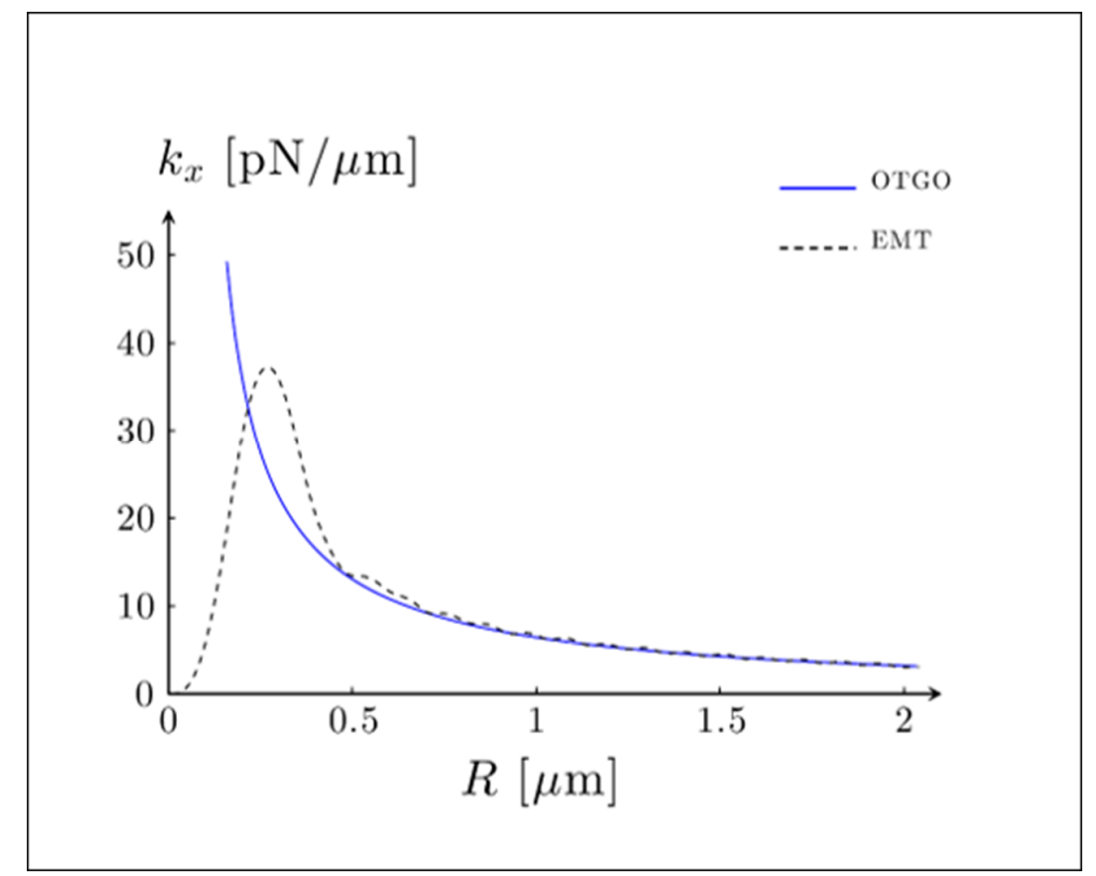

5. ábra Egy R sugarú, vízben lévő dielektrikum gömb (n=1.52) 632 nm hullámhosszú és 1.2 numerikus apertúrájú Gauss nyalábbal történő megvilágítása esetén a csapda rugóállandója geometriai (OTGO) és a hullámoptika (EMT) alapján becsült értékének összehasonlítása a gömb átmérőjének függvényében. Jól látható, hogy $\mathrm{R}>>\lambda$ esetén a geometriai optikai közelítés nagyon jó egyezésben van a hullámoptikai közelítéssel [105].

A két „szélsőség” közé eső mérettartományban - ahol a részecskeméret a hullámhossz nagyságrendjében van (Mie tartomány) - a pontos számoláshoz a Maxwell egyenletek vektori alakjának a megoldása szükséges. A probléma megoldására számos közelítés létezik. Bizonyos geometriák esetén viszonylag egyszerű a megoldás, míg általánosabb esetekben numerikus megoldás szükséges.

A probléma megoldására az egyik közelítés, ahol a Maxwell-féle stressz tenzor részecske felületére történő integrálásával határozták meg a részecskére ható erőt $[107,108,109]$. Ez a modell csak a hullámhossznál kisebb méretü gömbök esetén ad jó eredményt. A modell egyik korlátozó tényezője, hogy a fókusz körüli tartományban nem ad realisztikus közelítést a beérkező nyaláb térerősségéről. A beérkező nyaláb vektordiffrakciós közelítésével, illetve a Maxwell féle stressz tenzor alkalmazásával azonban a modell jól közelíti a kísérleti eredményeket [110]. 
A Rayleigh-Debye elmélet kiterjesztésével, amely másodrendű szórást (second-order scattering) is magába foglal, a számolások tetszőleges alakú részecskére is alkalmazhatók. E modellek azonban csak olyan kisméretü részecskékre adnak elfogadható eredményt, amelyekben a fáziseltolódás kisebb, mint $\pi / 3$ [111, 112].

Az optikai csipesz által kifejtett erő meghatározására egyik legalkalmasabb eljárás az általánositott Lorenz-Mie elméleten alapszik. A beérkező és a szórt térerősségeket a vektor harmonikus gömbfüggvények szerinti kifejtésének segítségével írják le, és a kifejtésben használt együtthatók közötti $\mathrm{T}$ transzformációs mátrixot a peremfeltételek segítségével határozzák meg. A módszer erről kapta a nevét: T-mátrix módszer. Előnye az összes egyéb módszerrel szemben, hogy a Tmátrix csak a részecske alakjától függ és ezt elegendő egyszer meghatározni, ami jelentősen lecsökkenti a számolási időt például egy fluktuáló részecske modellezése esetén [113].

Numerikus módszerek közül az egyik leggyakoribb a DDA (discrete dipole approximation) eljárás, ahol az anyagot elemi dipólusokra bontják fel, és azok elektromágneses mezővel való kölcsönhatását vizsgálják. Az erő és nyomaték az egyes dipólusokra ható erőből és nyomatékból, illetve ezek teljes testre vett integráljából származtatható. A DDA módszer segítségével a fényszórás és a részecskére ható erők meghatározása mindhárom tartományban elvégezhető [114, 115, 116]. További lehetőség a FDTD (finite difference time domain) módszer, ami a Maxwell egyenleteket a véges differenciák módszerével oldja meg [117, 118].

\subsubsection{Geometriai optikai közelítés}

Az alábbi esetben azt vizsgáljuk, hogy mi történik abban az esetben, ha egy fókuszált nyalábbal megvilágítunk egy gömböt [101]. Geometriai optikai közelítésben úgy kezeljük a nyalábot, mintha különálló sugarakból állna. Minden sugár egyenes vonalon terjed, amíg a dielektrikum gömb felületével nem találkozik. A sugarak viselkedését a felületen - azaz annak visszaverődését, megtörését, illetve a polarizáció változását - a Fresnel formulák határozzák meg.

A vizsgálódásunkat kezdjük azzal az esettel, amikor egyetlen sugár útját követjük a dielektrikum gömb belsejében a 6 . ábrán látható módon. A sugár a gömbön történő áthaladás során annak felületével találkozva minden alkalommal megtörik, illetve visszaverődik. A sorozatos törés és visszaverődés következtében a $P$ teljesítményü belépő sugár számos részsugárra bomlik fel úgy, 
hogy a $P$ teljesítmény eloszlik a $P R$ belépés során visszavert és a gömbből kilépő és fokozatosan csökkenő $P T^{2} R^{n}(n=1 \ldots \infty)$ teljesítményű sugarak között, ahol $T$ és $R$ a gömb felületén áthaladó, illetve visszaverődő teljesítményhányad (amit a Fresnel egyenletek segítségével lehet számolni), $n$ a visszaverődések száma. Egyetlen sugár által a gömbre kifejtett eredő erő az egyes részsugarak hatásának összegzésével nyerhető, ami két egymásra meröleges komponensre bontható fel az alábbiak szerint [119]:

$$
\begin{gathered}
F_{S}=\frac{n_{1} P}{c}\left\{1+R \cos 2 \theta-\frac{T^{2}[\cos (2 \theta-2 \phi)+R \cos 2 \theta]}{1+R^{2}+2 R \cos 2 \phi}\right\} \\
F_{G}=\frac{n_{1} P}{c}\left\{R \sin 2 \theta-\frac{T^{2}[\sin (2 \theta-2 \phi)+R \sin 2 \theta]}{1+R^{2}+2 R \cos 2 \phi}\right\}
\end{gathered}
$$

Az egyik komponens a belépő sugár eredeti terjedési irányába mutat, amit szórási erőnek $F_{S}$ neveznek, míg a másik komponens a gradiens erő $F_{G}$, ami a $F_{S}$ komponensre merőleges, ahogy az a 7. ábrán megfigyelhetö. $P$ a sugár teljesítményét, $c$ a vákuumbéli fénysebességet, $n_{1}$ a dielektrikum gömböt körülvevő közeg törésmutatóját jelöli, $\theta, \phi$ a beesési és törési szög.

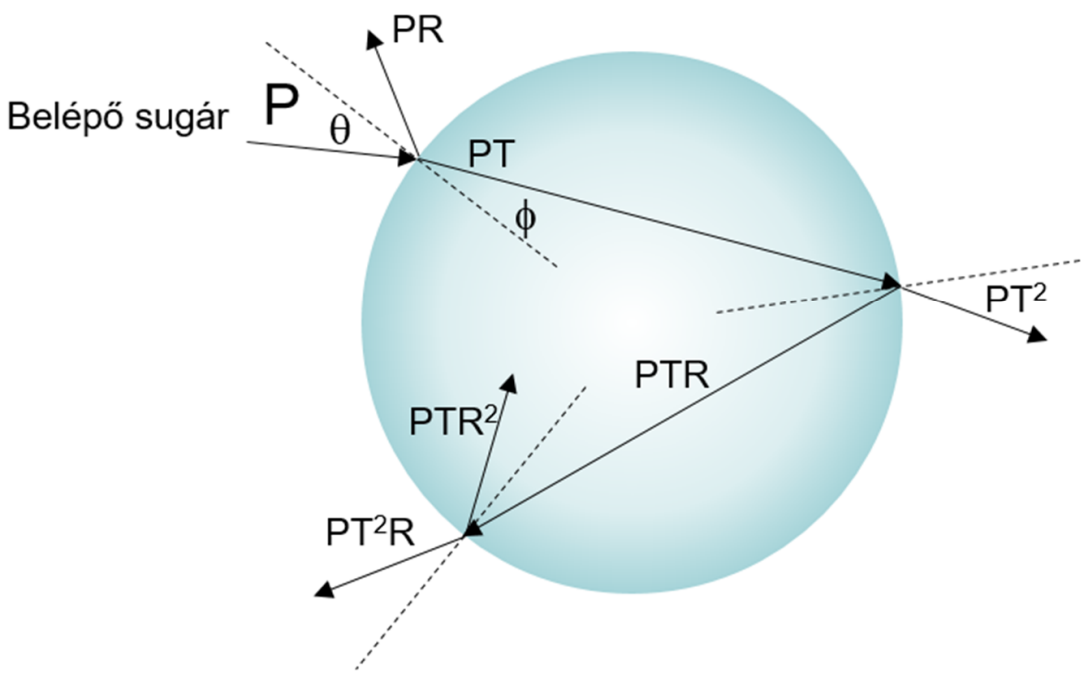

6. ábra Egy sugár kölcsönhatása a dielektrikum gömbbel. A $T$ és $R$ a Fresnel egyenletek segítségével számolható transzmissziós és reflexiós együtthatók. 
Egyetlen sugár hatását ismerve geometriai optikai közelítésben könnyen kiszámolható az eredő erő egy nagy numerikus apertúrájú mikroszkóp objektíven keresztül történő megvilágítás esetén is. Válasszunk olyan viszonyítási rendszert, ahol az origó a gömb középpontjával esik egybe, ahogy a 7. ábrán lehet látni. Azt fogjuk vizsgálni, hogy milyen erők hatnak a gömbre, ha a nyaláb eredeti fókuszpontjának helyzetét (amikor a gömb nincs behelyezve) változtatjuk a gömb középpontjához (origóhoz) viszonyítva. A z tengely az optikai tengellyel párhuzamos (mivel a viszonyítási rendszer a gömbhöz van rögzítve, a kettő nem azonos), a gömböt megvilágító nyaláb a z tengely mentén a negatívtól a pozitív irányba halad (az objektív kilépő apertúrája a z tengely mentén a negatív irányban van). A nagy numerikus apertúrájú megvilágítást sugarakra bontva és az egyes sugarakra számolt szórási és gradiens erőket összegezve megkapjuk a gömbre ható eredő eröt $F_{t o t}=\left(F_{S}^{2}+F_{G}^{2}\right)^{0.5}$.

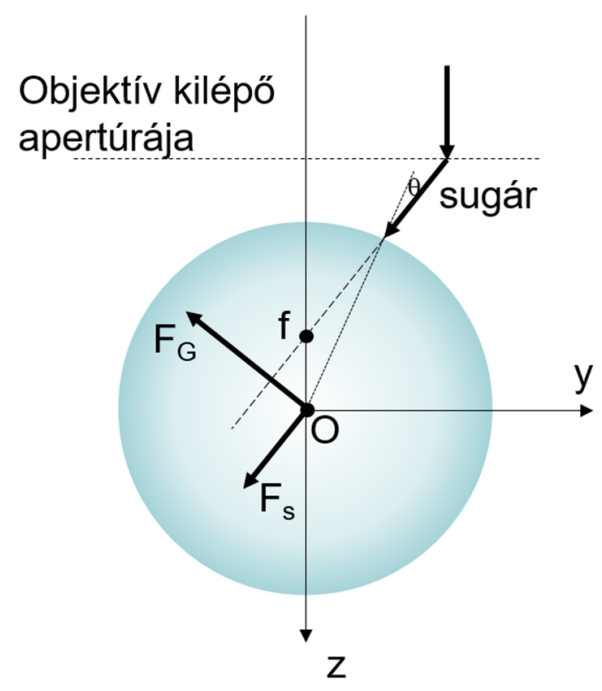

7. ábra Egyetlen belépő sugár által keltett szórási és gradiens erő. $f$ az objektív fókuszpontja, $O \mathrm{a}$ gömb (és a viszonyítási rendszer) középpontja, $F_{S}$ a szórási, míg $F_{G}$ a gradiens eröt jelöli.

A (39) és (40) egyenletek alapján a gömbre hatő erőket az alábbi alakban lehet felírni:

$$
F=Q \frac{n P}{c}
$$

A $Q$ egy dimenziómentes paraméter, ami csak a sugár beesési szögétől, illetve annak polarizációjától függ. Az $n P / c$ egy erő dimenziójú mennyiség. A fenti összefüggés segítségével be 
lehet vezetni a $Q_{S}$ és $Q_{G}$ mennyiségeket, amik a szórási és gradiens erőhöz rendelt $Q$ paramétereket jelölik, illetve a gömbre ható eredő erő a $Q$ paraméterek segítségével kifejezve: $Q_{t o t}=\left(Q_{S}^{2}+Q_{G^{2}}\right)^{0.5}$. A 8. ábrán figyelhetjük meg, hogyan változik az egyes $Q$ paraméterek nagysága és iránya, ahogy a fókuszpont helyzetét változtatjuk a gömb középpontjához képest. A példaként bemutatott számolásban a fókuszáló objektív apertúrája homogén kitöltésű, a nyaláb cirkulárisan polarizált, a gömb effektív törésmutatója $n=1.2$ és a numerikus apertúra 1.25.
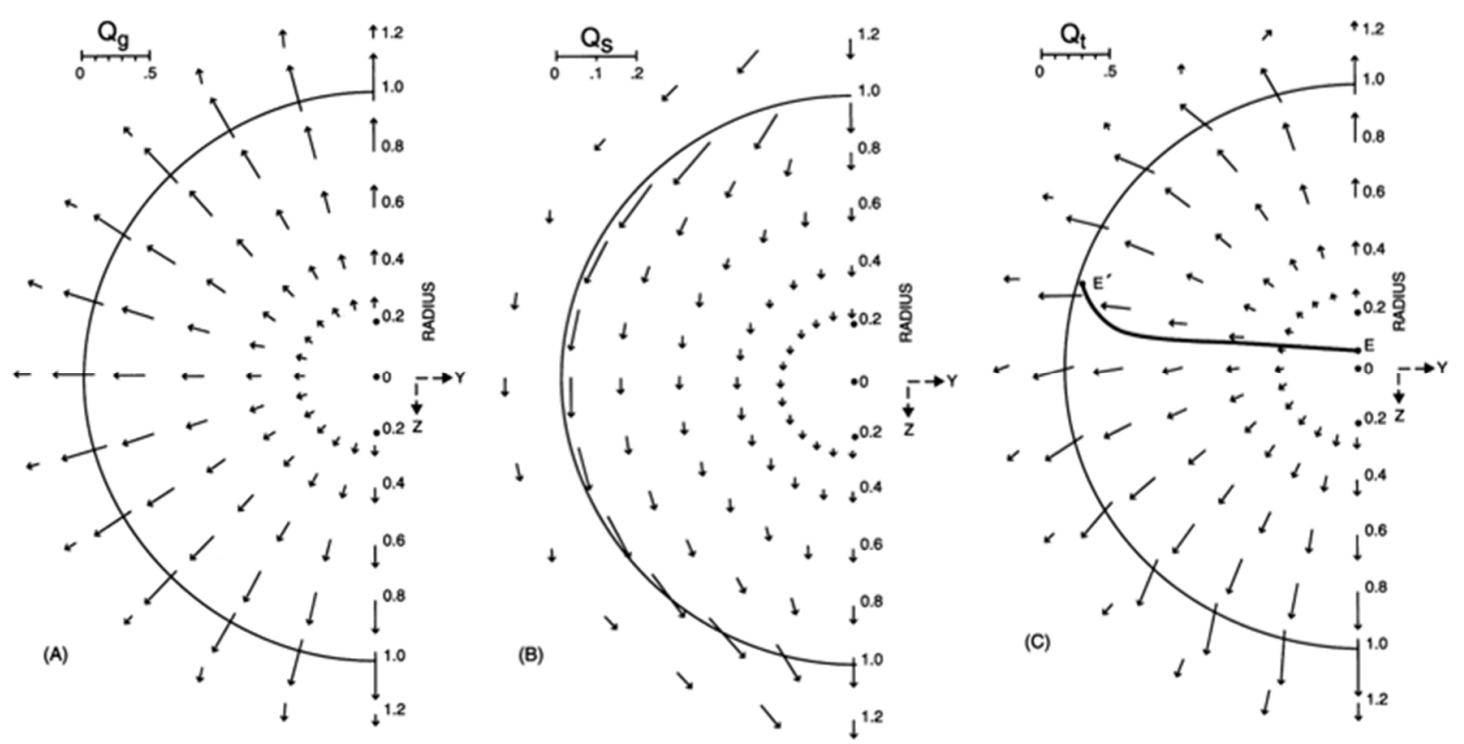

8. ábra Q paraméterek nagysága és iránya a fókusz gömbön belüli helyzetének függvényében (z irány az optikai tengely, a megvilágítás „fentről” érkezik). A nyilak a gömbre ható erők irányát jelölik. A számolásban a fókuszáló objektív apertúrája homogén kitöltésü, a nyaláb cirkulárisan polarizált, a gömb effektív törésmutatója $\mathrm{n}=1.2$ és a numerikus apertúra 1.25. Az E-E' vonal azokat a pontokat köti össze, ahol a gömbre ható teljes erő függőleges komponense 0 [101].

A Q paramétereket megvizsgálva megállapítható, hogy egyetlen nyalábbal is lehetséges stabilan három dimenzióban csapdázni, amit a gradiens erő tesz lehetővé. A gradiens erő a gömböt mindig a fókuszpont felé húzza, amíg a fókusz a gömbön belül helyezkedik el. Ahogy a nyaláb fókusza a gömbön kívülre kerül, illetve attól távolodik, a gradiens erő nagyon gyorsan eltünik. Ezzel szemben a szórási erő önmagában stabil csapdázásra nem képes. Mivel mindig van pozitív z irányú komponense, a csapdázás hatékonyságát az optikai tengely irányában csökkenti. 
A 8.b) ábrán a gömb középpontját jelölő pont megtévesztő lehet, ugyanis az nem a szórási erőt mutatja. A szórási erő értéke soha nem lesz 0 , emiatt a stabil csapdázás helye a gömb középpontja felett van, amit a 8.c) ábrán az E pont jelöl. Az E-E' vonal azokat a pontokat köti össze, ahol a gömbre ható teljes erö függőleges komponense 0 .

\subsubsection{Holografikus optikai csipesz felépítése}

Az optikai csipeszek egyik legfejlettebb típusa, amely a csapdák számának, pozíciójának, módusának és minőségének legszélesebb körü vezérlését teszi lehetővé a holografikus optikai csipesz. Egy holografikus optikai csipeszt megvalósító optikai elrendezés, ami lényegében megegyezik az általam használt optikai elrendezéssel, elvi vázlata a 24. ábrán (4.5. fejezetben) látható. Felsorolásképpen a főbb alkotó elemei: lézer, nyalábtágító, vezérlő optika, illesztő optika, dikroikus tükör, nagy numerikus apertúrájú objektív, mintatartó, kamera [120]. Az alábbiakban részletezem a lényeges komponenseket.

\subsubsection{Lézer}

Az egyik legfontosabb alkotórésze az optikai csipesznek a lézernyaláb, amit fókuszálva lehetővé válik a csapdázás. A lézer megválasztása során legfontosabb tényezők, amiket figyelembe kell venni: hullámhossz, teljesítmény, polarizáció és nyalábminőség.

A hullámhossz megválasztása elvileg tetszőleges, azonban szem előtt kell tartani, hogy sem a csapdázni kívánt objektum, se pedig a közeg ne nyelje el a csapdázó fényt. A fókuszban az intenzitás rendkívül nagy - akár a $\mathrm{MW} / \mathrm{cm}^{2}$ nagyságrendet is meghaladhatja -, már csekély mértékü fényelnyelés is a minta roncsolódását vonja maga után. Mivel az optikai csapdázás leggyakrabban vízben történik (aminek 1090nm környékén abszorpciós minimuma van), tipikusan a közeli infravörös tartományt szokták csapdázás céljára használni. A hullámhosszal erösen összefügg, hogy mekkora lehet az alkalmazott kilépő lézerteljesítmény. Továbbra is a minta roncsolási küszöbe az egyik irányadó, ami a különböző hullámhosszakon eltérő lehet. Másrészt figyelembe kell venni másodlagos folyamatokat, amelyek nem a közvetlen abszorpciótól származnak. Például biológiai minták esetén az optikai csapdázás az elhanyagolható abszorpció ellenére is könnyen a sejtek pusztulásához vezet [121], így az alkalmazott teljesítmény jellemzően a mW - 100mW közötti tartományban van. 
A polarizációnak akkor juthat fontos szerep, ha a csapdázott objektum orientálása szükséges. Ha az objektumnak van valamilyen speciális alakja (pl.: elnyújtott alakú), vagy optikailag anizotróp (pl.: kettősen törő), akkor lineárisan polarizált fény alkalmazása során a struktúra orientálódik a polarizáció irányába, vagy arra merőlegesen [122, 123]. Cirkulárisan polarizált fény alkalmazásával a csapdázott objektum akár forgásba is hozható [123].

A jó csapdázási hatásfok érdekében rendkívül fontos a jó nyaláb minőség: leggyakrabban TEM00 Gauss intezitáseloszlású nyalábot szoktak használni. Rendkívül fontos még a nyaláb stabil iránytartása, mert az instabilitások nem kívánt fluktuációkhoz vezetnek a csapdázás során.

\subsubsection{Vezérlö optika}

Abban az esetben, ha a vezérlő optika helyén egy fix tükröt alkalmazunk, akkor egy egyszerü egynyalábos optikai csipeszt kapunk. Ha szeretnénk vezérelni a csapdát - a pozícióját tetszőlegesen változtatni a mintatérben - vagy több csapdát szeretnénk létrehozni (illetve ezeket egymástól függetlenül vezérelni), akkor annak legjobb módja a térbeli fénymodulátor alkalmazása.

\subsubsection{Térbeli fénymodulátor (SLM)}

Manapság az optikai csipeszek vezérlésére leggyakrabban alkalmazott eszköz a SLM - Spatial Light Modulator. A SLM általános elnevezés azokra az eszközökre, amelyekkel a fény intenzitása, polarizációja vagy fázisa időben és térben modulálható. Számos fajtája létezik, forgatható mikrotükrök, deformáható tükrök, folyadékkristályos eszközök, stb... Az általunk használt folyadékkristályos eszközökben a nyaláb pixelekre osztott aktív felületen halad át. Minden egyes pixelt egy mikrocella alkot, amelyekben follyadékkristály van: olyan molekulák, amelyek orientációja és ezáltal az optikai tulajdonsága elektromos tér függő. Minden egyes cella, azaz minden pixel a rákapcsolt feszültséggel egyedileg szabályozható, és a belépő fény fázisa pixelenként 0 és $2 \pi$ közötti tartományban eltolható. A fény fázisfrontjának alakításával szinte tetszőleges számú csapda hozható létre a mintatérben, és ezek egymástól függetlenül vezérelhetők. Azt a fázisképet, amelyet az SLM kijelzőjén megjelenítünk - nevezzük hologramnak (és ebből következik a holografikus optikai csipesz elnevezés is) - számítás útján lehet meghatározni [124, $125,126]$. 


\subsubsection{Nyalábtágító}

A holografikus optikai csipeszben az SLM előtt elhelyezett nyalábtágító elsődleges szerepe a nyaláb méretének az SLM aktív felületéhez történő igazítása.

\subsubsection{Illesztö optika}

Az SLM után úgynevezett 4f-elrendezésben egy újabb lencsepárt szoktak elhelyezni, amit a 9. ábra szemléltet. A 4f-elrendezés onnan származik, hogy két lencse konfokálisan van a fényútba helyezve, úgy hogy az első lencse elülső fókuszsíkjában a SLM van.

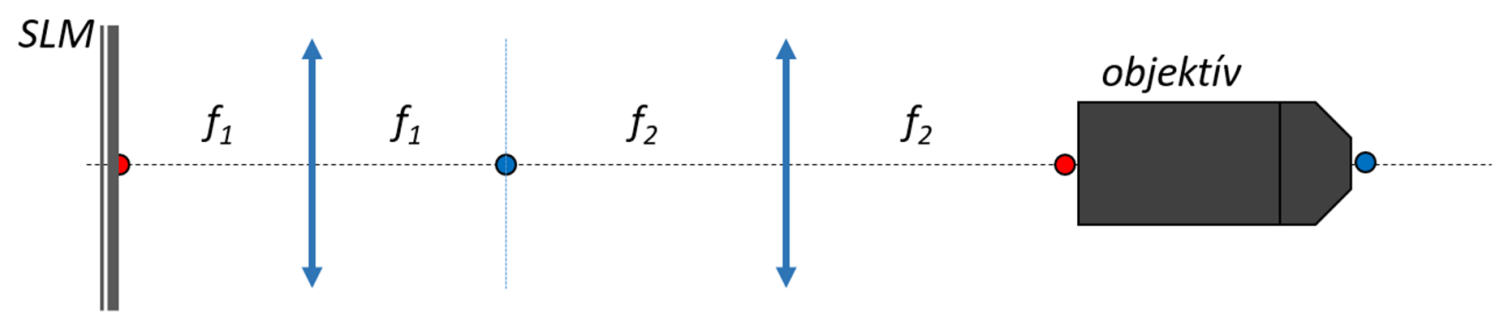

9. ábra A 4f-elrendezés sematikus rajza.

A illesztő optikának kettős célja van. Egyrészt az SLM aktív felületének a mérete és az objektív belépő apertúrájának mérete általában nem egyezik meg, emiatt a SLM-ről visszaverődő lézer nyalábot úgy kell tágítani, vagy szükíteni, hogy igazodjon a mikroszkóp objektív belépö apertúrához. Mivel a csapdázásra használt lézer intenzitáseloszlása folytonos (leggyakrabban TEM00), fontos kérdés, hogy az objektív belépő apertúrájához viszonyítva mekkora legyen a nyaláb mérete. Mivel a csapdázás hatásfoka függ az objektum méretétől, törésmutatójától és alakjától is, változó eredményre jutottak a kérdéssel kapcsolatban: egyes publikációkban az objektív túltelítését [101, 127, 128], míg mások ellenkezőleg az objektív részleges kitöltését javasolják [129, 130, 131]. Ennek megfelelően, ha a csapdázási hatásfok kritikus paraméter, akkor az objektív kitöltését az adott probléma határozza meg. A két lencse fókusztávolságának nem szükségszerü megegyeznie, így a fókusztávolságok arányának megfelelő megválasztásával a nyalábméret tetszőlegesen állítható.

Az illesztő optika másik feladata, hogy a SLM segítségével beállított térerősség amplitúdóját és fázisát az objektív hátoldali fókuszsíkjában előállítsa. A 4-f elrendezésben pontosan ez történik, ugyanis az első lencse előtti fókuszban a térerősség (amplitúdó és fázis) lényegében megegyezik 
a második lencse mögötti térerősséggel, amit a 9. ábrán piros pontok jelölnek. Ez a tulajdonság könnyen megérthető a lencsék Fourier transzformációs tulajdonságait felhasználva: egy lencse hátoldali fókuszsíkjában megjelenő térerősség az elülső oldali fókuszsíkban levő térerősség Fourier transzformáltja lesz [132]. A két lencse alkalmazásával a Fourier transzformációt kétszer kell végrehajtani, így gyakorlatilag visszakapjuk az eredeti térerősséget (pontosabban annak fordított állású képét: $F\{F\{t(x, y)\}\}=t(-x,-y))$ ahol $t(x, y)$ a térerősség az első lencse elötti fókuszsíkban, $F\{$ \} pedig a Fourier transzformációt jelöli.

\subsubsection{Dikroikus tükör}

Mivel a csapdázás és a megfigyelés ugyanazon objektíven keresztül történik, szükséges a két fényút szétválasztása. Erre a célra leggyakrabban dikroikus tükröket alkalmaznak, ami általában csak a csapdázó lézer hullámhosszán rendelkezik magas reflexióval és szerepe, hogy a csapdázó nyalábot az objektív felé terelje, illetve rajta keresztük a minta megfigyelhetö legyen.

\subsubsection{Mikroszkóp objektív}

Az optikai csipesz másik legfontosabb eleme a mikroszkóp objektív. Az objektív egyik legfontosabb tulajdonsága a nagy numerikus apertúra, ami jellemzően 1-nél nagyobb. A nagy numerikus apertúrára azért van szükség, mert az optikai tengely mentén történő csapdázásért az optikai tengellyel nagy szöget bezáró sugarak a felelősek. Erre a célra jellemzően víz-, vagy olajimmerziós objektíveket alkalmaznak. 


\subsection{Kétfotonos polimerizáció}

\subsubsection{Polimerizáció}

Fotopolimerizálás egy olyan fotokémiai reakció, amelyet fényre érzékeny anyagokban (ún. fotorezisztek) megfelelő hullámhosszú fénnyel való megvilágítással váltanak ki. A megvilágítás hatása alapján a fotorezisztek két osztályba sorolhatók: a negatív és pozitív fotorezisztek. A negatív fotorezisztek esetében a besugárzott tartományban olyan folyamatok játszódnak le, aminek következtében az a rész az előhívó számára oldhatatlanná válik, míg pozitív fotorezisztek esetében fordított a helyzet, a megvilágítatlan rész oldhatatlan marad. Ezt a folyamatot kihasználva tetszőleges alakú struktúrákat lehet létrehozni. A nem polimerizálódott részt az úgynevezett előhívási folyamatok során lehet eltávolítani. A fotopolimerizáció céljából alkalmazott hullámhossz tipikusan az ibolyántúli és az infravörös közötti tartományba esik, bár egyéb hullámhosszú sugárzások is alkalmasak lehetnek a reakció kiváltására.

A dolgozatban szereplő struktúrákat negatív polimerekből készítettem, ezért a következőkben az ezekre jellemző fotokémiai folyamatokat mutatom be. A fotopolimer anyagoknak legalább két összetevőjük van: az iniciátor és a monomer. Az iniciátor szerepe, hogy a fényt elnyelje, miáltal gerjesztett állapotba kerül és így képessé válik a monomerek közötti kémiai reakciókat inicializálva azokat összekapcsolni. Az összekapcsolódásnak két alapvető típusa létezik: a polimerizáció és a keresztkötések kialakitása. Megtévesztő lehet az elnevezés, hogy a „polimerizáció”, mint összefoglaló név, és mint az egyik altípus megnevezése megegyezik, de a szakirodalomban ez az elterjedt szóhasználat.

A polimerizáció legjellemzőbb vonása, hogy a fénnyel gerjesztett iniciátor egy láncreakciót indít el. A gerjesztett iniciátor egy monomert gerjesztett állapotba hoz, miáltal az képes egy másik monomerrel kémiai kötést létrehozni. Az összekapcsolódás után a második monomer kerül gerjesztett állapotba, miáltal a második monomer képes egy további monomerrel összekapcsolódni, és így tovább... Az így kialakult monomerekből álló láncot nevezik oligomernek. A láncreakció úgy zárulhat, ha két gerjesztett oligomer találkozik. A láncreakciót az alábbi séma szemlélteti:

$$
\begin{gathered}
I \stackrel{h v}{\longrightarrow} I^{*} \rightarrow R \cdot \\
R \cdot+M \rightarrow R M \cdot \stackrel{M}{\longrightarrow} R M M \cdot \ldots \stackrel{M}{\longrightarrow} R M_{n} M .
\end{gathered}
$$




$$
\begin{gathered}
R M_{m} M \cdot+R M_{n} M \cdot \rightarrow R M_{m+n+2} R \\
R M_{m} M \cdot+R M_{n} M \cdot \rightarrow R M_{m} M+R M_{n} M
\end{gathered}
$$

ahol I az iniciátor, I* a gerjesztett állapotú iniciátor, $\mathrm{R} \cdot$ aktivált iniciátor, $\mathrm{M}$ monomer, a „," az aktivált állapotot jelöli. A keresztkötések kialakítása során az iniciátor gerjesztésén keresztül kapcsol össze két monomert, vagy oligomert, de ez a reakció itt megáll.

Míg a polimerizáció során egyetlen foton indítja a folyamatot, amely akár több száz monomer összekapcsolódását eredményezheti, addig a keresztkötések kialakítása során minden egyes összekapcsoláshoz szükséges egy iniciátort fénnyel gerjeszteni [133].

\subsubsection{Kétfotonos abszorpció}

A fotopolimerizációt akkor nevezzük kétfotonosnak, ha a kezdő lépésben az iniciátor kétfotonos abszorpció révén gerjesztődik (az angol two-photon polymerization terminológia után a rövidítése: TPP). A kétfotonos abszorpció kétféleképpen mehet végbe: lépcsősen és egyidejüleg. Az első esetben létezik egy valós közti állapot, amely eléréséhez fele annyi energiára van szükség, mint a gerjesztett állapot eléréséhez. Ennek a folyamatnak nem feltétele a koherencia nem úgy, mint a második esetben. Az egyidejű kétfoton abszorpciós folyamat esetén az elektron közel egyidejüleg abszorbeál két fotont. Az elektron egy foton energiájának felvétele során egy virtuális állapotba kerül, amely meglétének időtartama femtoszekundumos nagyságrendű. Amennyiben a második foton ez idő alatt érkezik, kétfotonos abszorpció valósul meg. TPP-vel a térbeli részletek minimális mérete konvencionális módon 150nm körül [134, 135, 136], de iniciátor legerjesztésen alapuló módszerekkel 50nm körülire csökkenthető [137, 138].

\subsection{3. $S U 8$}

A dolgozatomban SU8 fotopolimerből készült struktúrákat mutatok be, ezért részletesebben bemutatom ezt az anyagot. Az SU8 fotopolimert hagyományosan mikroelektronikai gyártási folyamatok során maszk fotolitográfián alapuló eljárásokban alkalmazzák. Negatív fotoreziszt, amely UV, tipikusan 400nm-nél rövidebb hullámhosszú megvilágítás hatására keményedik meg. A kereskedelemben kapható változatai fotoiniciátort, monomert és oldószert tartalmaznak. Az oldószer szerepe a folyadék viszkozitásának beállítása, amely segítségével a felületre felvitt SU8 réteg vastagsága szabályozható. A 10. ábrán látható egy SU8 monomer szerkezeti képlete. A 
molekula polimerizációban funkcióval bíró része az ábrán pirossal bekarikázott epoxi gyürü, amely a fotokémiai reakció során felhasad és hozzákapcsolódik egy másik monomerhez. [139]

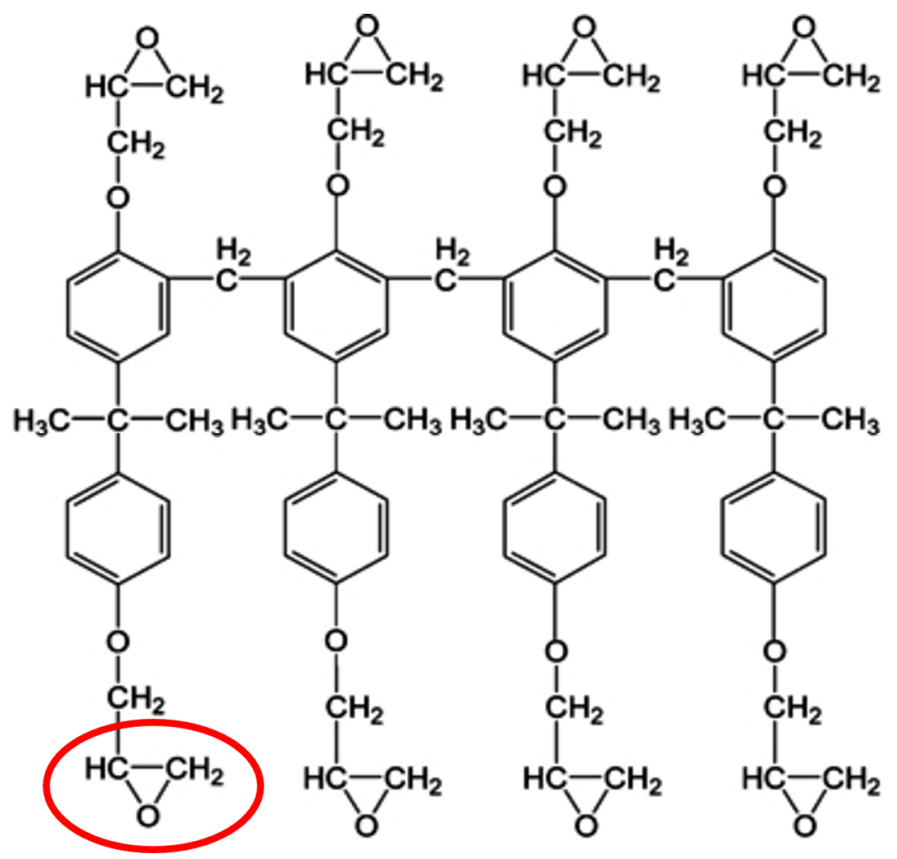

10. ábra SU8 monomer. A bekarikázott rész a fotopolimerizáció során funkcióval bíró epoxi gyürü. 


\section{Célkitüzés}

A dolgozatomban olyan fénnyel hajtott mikroszkopikus robotrendszerek kidolgozását tủztem ki célul, amelyek segítségével két problémakör, mégpedig a mikroszkopikus mozgás, illetve a hidrodinamikai szinkronizáció vizsgálható.

\subsection{Fénnyel hajtott, autonóm módon mozgó mikroszkopikus testek.}

A mikroszkopikus mozgás kérdéskörében olyan mozgó testeket akartam kifejleszteni, amelyeknek a mozgáshoz szükséges energiát a fény szolgáltatja, de önállóan mozognak, abban az értelemben, hogy a mozgásuk irányát nem a fény határozza meg. Ez a követelmény jelentősen eltér a fény hajtotta mozgások korábban tárgyalt eseteitől. A fény hajtotta mozgás legegyszerübb esetében a fénnyel kölcsönható test a fény haladási irányában mozdul el. Test mozgatása lézercsipesszel is egyszerủen megoldható, ekkor viszont a lézercsipesz helyzetét mozgatják, és a megragadott test is ennek megfelelően mozog. A kifejlesztendő robotokkal szemben támasztott követelmény tehát az, hogy a mozgás irányát a robotok maguk (alakjuk, helyzetük, stb.) határozzák meg. További követelmény, hogy mozgásuk rendezett és iránytartó legyen, vagyis a mozgás pályájához rendelhető perzisztenciahossz jóval nagyobb legyen, mint a test mérete. A vizsgált elrendezésben a robotok vizszintes sík felületen mozognak, a mozgást hajtó fény pedig széles homogén kollimált nyalábban függőlegesen lefele, a síkra merölegesen érkezik.

Kétféle mikrorobot elkészítését terveztem: az egyik típus ék alakú, és felületen történő csúszással, míg a másik guriga alakú és gördüléssel halad. A testeket kétfotonos gerjesztésü fotopolimerizációval kívántam kialakítani, majd müködésük demonstrálását és a mozgásuk részletes jellemzését tüztem ki célul. 


\subsection{Hidrodinamikai szinkronizáció}

Munkacsoportunkban korábban kidolgoztak egy rendszert, amelyben fénnyel hajtott forgást lehet vizsgálni [98]. Kétfotonos fotopolimerizációval mikronos méretü rotorokat hoztak létre, ezeket lézercsipeszben csapdázva forgásba lehet hozni. E rendszer kiváló lehetöséget nyújt fény hajtotta forgás részletes vizsgálatára. Doktori munkámban e fénycsipeszben rögzített és fénnyel hajtott rotorokat terveztem alkalmazni a hidrodinamikai szinkronizáció kimutatására és vizsgálatára.

A szinkronizáció vizsgálata során elsődleges cél a hidrodinamikai szinkronizáció demonstrálása volt a mikroszkopikus mérettartományban mesterséges objektumokkal, kontrollálható körülmények között. Ennek megvalósítására tehát a fénnyel készített és fénnyel hajtott rotorok rendszerét kívántam alkalmazni illetve továbbfejleszteni. Olyan mikrorobotokat terveztem létrehozni, amelyek fény hatására forgómozgást végeznek egy jól meghatározott helyzetü tengely körül. A rendszernek képesnek kell lenni két mikrorobot együttes vezérlésére, a relatív sebességük és helyzetük nagy pontosságú hangolására, illetve a mozgás precíz jellemzésére. A hidrodinamikai szinkronizáció demonstrálásán túl célul tűztem ki a jelenség részletes elemzését, illetve matematikai modelljének felállítását is. 


\section{Elmélet}

\section{1. Ék alakú struktúrák mozgása}

Vizsgáljuk meg először analitikusan egy ék mozgását megvilágítás hatására. A számolásban azt feltételeztem, hogy a megvilágítás homogén (egyenletes eloszlású sugarakból áll) és az ék alátámasztását szolgáló felületre merőlegesen érkezik. A számolásban geometriai optikai közelítést alkalmaztam. Tekintsük először azt az esetet, amikor az ék oldalnézetből egy derékszögü háromszög, ahogy az a 11. ábrán látható, amelyre vonatkozó eredmények felhasználásával egyszerüen levezethető egy tetszőleges háromszög keresztmetszetü ék esete is. Az ék felületéről veszteség nélkül verődik vissza a fény a szabályos visszaverődés szabályai szerint.

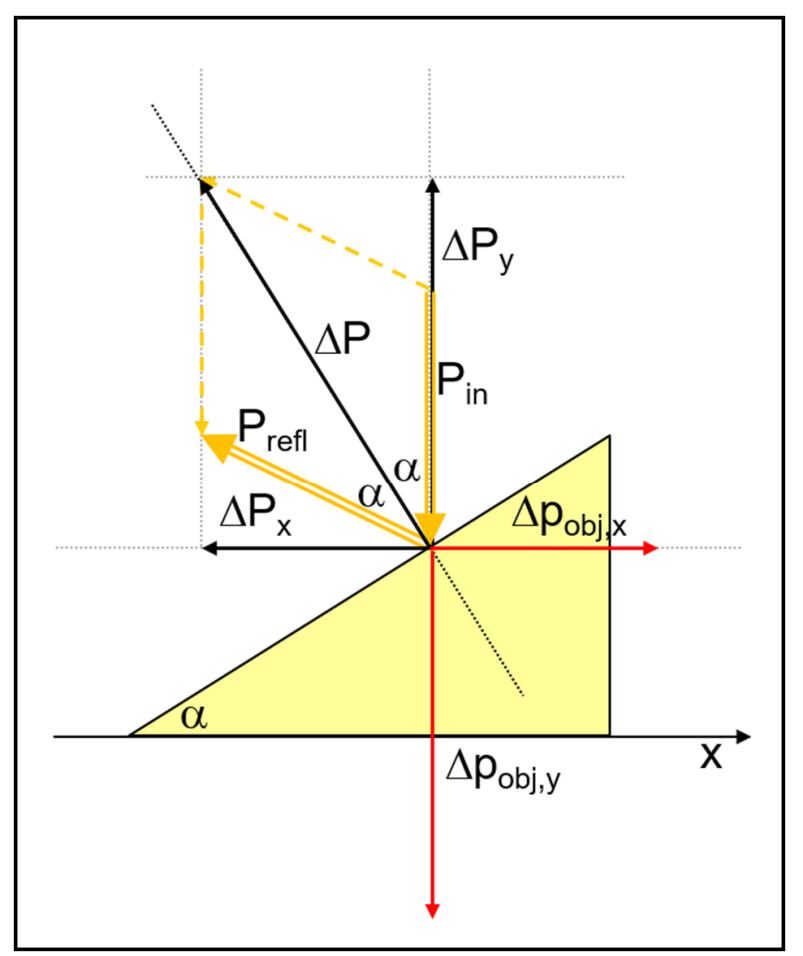

11. ábra Fény reflexió hatására egy ék alakú struktúrára ható erők származtatása.

Nyilvánvaló, hogy a derékszögü geometria esetén a megvilágítás hatására csak az egyik oldalon ébred erő. Az $\alpha$ beesési szöggel beérkező fénysugár és a visszavert fénysugár által bezárt szög $2 \alpha$. A szabályos visszaverődés következtében a fény impulzusának megváltozását a $\Delta P$ vektor mutatja. 
Az impulzus-megmaradásból következik, hogy a reflexió során ezzel egyenlő nagyságú, de ellentétes irányú impulzusváltozást szenved az ék. Ennek az impulzusváltozásnak lesz egy függőleges és egy vízszintes összetevője. A vízszintes (a 11. ábrán $x$ irányú) komponens hatására fog elmozdulni az ék, míg a függőleges ( $y$ irányú) komponens az éket a felülethez nyomja, így súrlódási erőt növelve az ék mozgását akadályozhatja. A felülettel párhuzamos komponens egyenlő nagyságú a $\Delta P$ vektor $x$ irányú komponensével, amiből az ékre ható erőt meg lehet határozni:

$$
\Delta P_{x}=P_{i n} \sin (2 \alpha)
$$

$I$ intenzitású megvilágítás esetén az egységnyi $A$ felületen $\Delta t$ időegység alatt $N$ számú $E$ energiájú foton halad át.

$$
I=\frac{N \cdot E}{\Delta t \cdot A}=\frac{N \cdot \frac{h c}{\lambda}}{\Delta t \cdot A}=\frac{N \cdot p \cdot c}{\Delta t \cdot A}=\frac{P \cdot c}{\Delta t \cdot A}
$$

ahol h Planck állandó, c a fénysebesség, p egy foton impulzusa, $\mathrm{P}$ a fotonok összes impulzusa. A (47) egyenletből az összes foton impulzusát kifejezve:

$$
P=\frac{I \cdot \Delta t \cdot A}{c}
$$

Visszahelyettesítve ezt a kifejezést a (46) egyenletbe megkapjuk az ékre ható vízszintes irányú erőt folyamatos I intenzitású megvilágítás hatására:

$$
\Delta F_{x}=\frac{I \cdot A}{c} \sin (2 \alpha)
$$

Hasonlóan származtatható a függőleges irányú erő is:

$$
\Delta F_{y}=\frac{I \cdot A}{c} \cos (2 \alpha)
$$




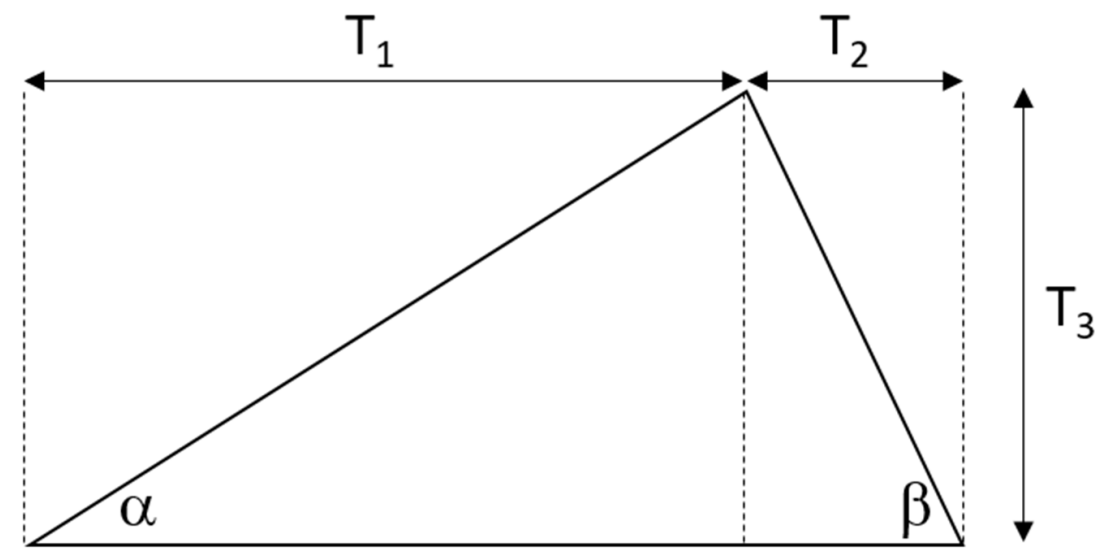

12. Geometriai viszonyok általános esetben.

Általános esetben, amit a 12. ábra szemléltet, amikor az ék oldalról nézve nem derékszögű, az erő mindkét oldalon fellép. Mivel bármely háromszög felbonható két derékszögü háromszögre, a (49) összefüggés alapján könnyedén számolhatók az ékre ható erők. Ha az egyik oldalon a hajlásszög $\alpha$, a másikon $\beta$, akkor a mindkét oldalon fellépő fényvisszaverödés következtében az ékre ható erő az alábbi módon fejezhető ki:

$$
F=\frac{I}{c}\left(T_{1} \cdot \sin (2 \alpha)-T_{2} \cdot \sin (2 \beta)\right)
$$

ahol a $T_{1}$ és $T_{2}$ az ék felületének a beeső fotonok irányára merőleges síkra eső vetülete. 


\subsection{Gurigák mozgása}

\subsubsection{Szimulációk}

A gurigák forgásának modellezését Oroszi László végezte el saját $\mathrm{C}++$ programnyelven írt szoftver segítségével. A szimulációban az alábbi feltevések és egyszerüsítések voltak bevezetve:

- A megvilágítás monokromatikus és homogén, ami a modellben egyenletes eloszlású párhuzamos sugarak összegeként jelenik meg. A sugarak a geometriai optika törvényei szerint haladnak és a trajektória a sugárkövetés (ray-tracing) módszerével lett meghatározva. A sugarak útját a fénytörés esetén Snellius törvény, és a Fresnel egyenletek, illetve visszaverődés esetén a szabályos visszaverődés törvényei határozták meg. A polarizáció szabadon változtatható paraméter volt. A szimulációkban egy orientáció kiszámolásában 100 sugár vett részt.

- A gurigák optikailag homogén módon viselkednek, három optikai tulajdonságú esetet vizsgáltunk: $i$ ) a test felülete tökéletesen fényvisszaverő; ii) átlátszó, és nem fényelnyelő (valós törésmutató); iii) fényelnyelő volt (komplex törésmutató).

- A szimulációban minden olyan helyen, ahol a beérkező sugár iránya megváltozik, vagy több sugárra esik szét, erőhatás lép fel. A szimulációban ezen erőket a beérkező fény impulzusának változásaiból lehetett meghatározni. Az erők forgatónyomatékának meghatározása a guriga forgástengelyére és az alátámasztó felület érintkezési pontjára (mint pillanatnyi forgástengelyre) is megtörtént. Mivel a két esetben az eredmény közel azonos volt, a dolgozatomban csak az utóbbi eredményekröl számolok be, amelyek a kísérletekkel történő összevetés szempontjából relevánsak. Amennyiben a guriga felszíne nem tökéletesen fényvisszaverö, akkor az áthaladás során egy sugár számos kisebb (elméletileg végtelen számú) sugárra esik szét. A szimulációban egy sugár (illetve a részsugarak) útja addig volt követve, amíg a gurigából kilépő sugarak összintenzitása a 99\%-ot el nem érte.

- A forgatónyomatékokat a struktúrák különböző orientációiban is kiszámoltuk, a forgás során az orientációt 1 fokos lépésekben változtatva. 


\subsubsection{Gurigák alakja}

A gurigákat alakjuk szerint két nagyobb csoportba lehet sorolni: i) prizmaszerü, vagy 2 dimenziós, illetve ii) 3-dimenziós gurigák.

i) Prizmaszerű guriga: Jellegzetes tulajdonságokkal rendelkeznek az úgynevezett prizma alakú gurigák. Ez a forma úgy állítható elő, hogy síkban megrajzoljuk az alapját, majd ezt a felületre merőleges tengely mentén kihúzzuk, a „3. dimenzióba is kiterjesztjük” a struktúrát, ahogy azt a 13.a) ábra is mutatja. Az így előállított 3 dimenziós geometriai test neve prizma.

a)

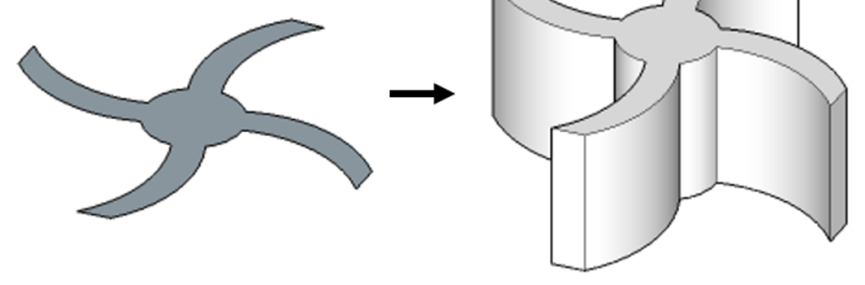

b)

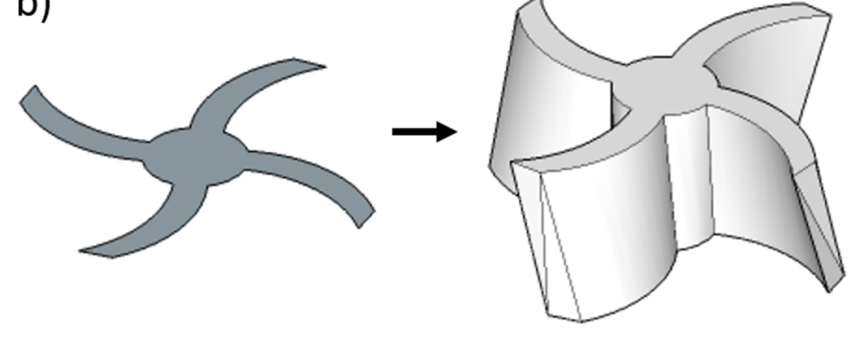

13. ábra a) A prizmaszerü és b) a 3D guriga előállítása.

ii) 3-dimenziós guriga: A valódi 3 dimenziós eset a 2 dimenziós esettől abban különbözik, hogy a

3. dimenzióba történő „kiterjesztés” során a forgástengely mentén is módosul az alak, például el is csavarjuk a struktúrát, ahogy a 13.b) ábrán látható.

A két alak között a lényegi eltérés akkor jelenik meg, amikor megvizsgáljuk, hogy mi történik egy a forgástengelyre merőlegesen érkező fénysugárral. Nyilvánvaló, hogy prizmaszerü struktúra esetében a sugár a struktúrával történő kölcsönhatás után számos részsugárra eshet szét, de ezen részsugarak mindegyike abban a síkban marad, ami a struktúra forgástengelyére merőleges, és 
amiben a beérkező sugár is érkezett. A fényszórás tehát 2 dimenziós. A 3-dimenziós struktúra esetén ez nem teljesül, a beérkező sugár olyan sugarakra eshet szét, amelyek tetszőleges irányba haladhatnak, a fényszórás 3 dimenzióban zajlik. Ez a viselkedés indokolja a 2-dimenziós, és 3dimenziós elnevezést.

A szimulációban használt struktúra elvi rajzát a 14. ábra mutatja. Mivel a struktúra sugara $(R)$ és a forgástengelyének hossza $(L)$ adott, a 3D guriga alakját egyetlen paraméter, a torzió szöge $(\theta)$ határozza meg. A torzió szöge azt adja meg, hogy a forgástengely közepétől az egyik, vagy másik végéig az L/2 hosszúságú szakaszon milyen mértékben csavarodik el a struktúra. A forgástengely mentén a struktúra közepétől balra, illetve jobbra haladva a torzió mértéke egyforma, viszont a helicitása ellentétes.

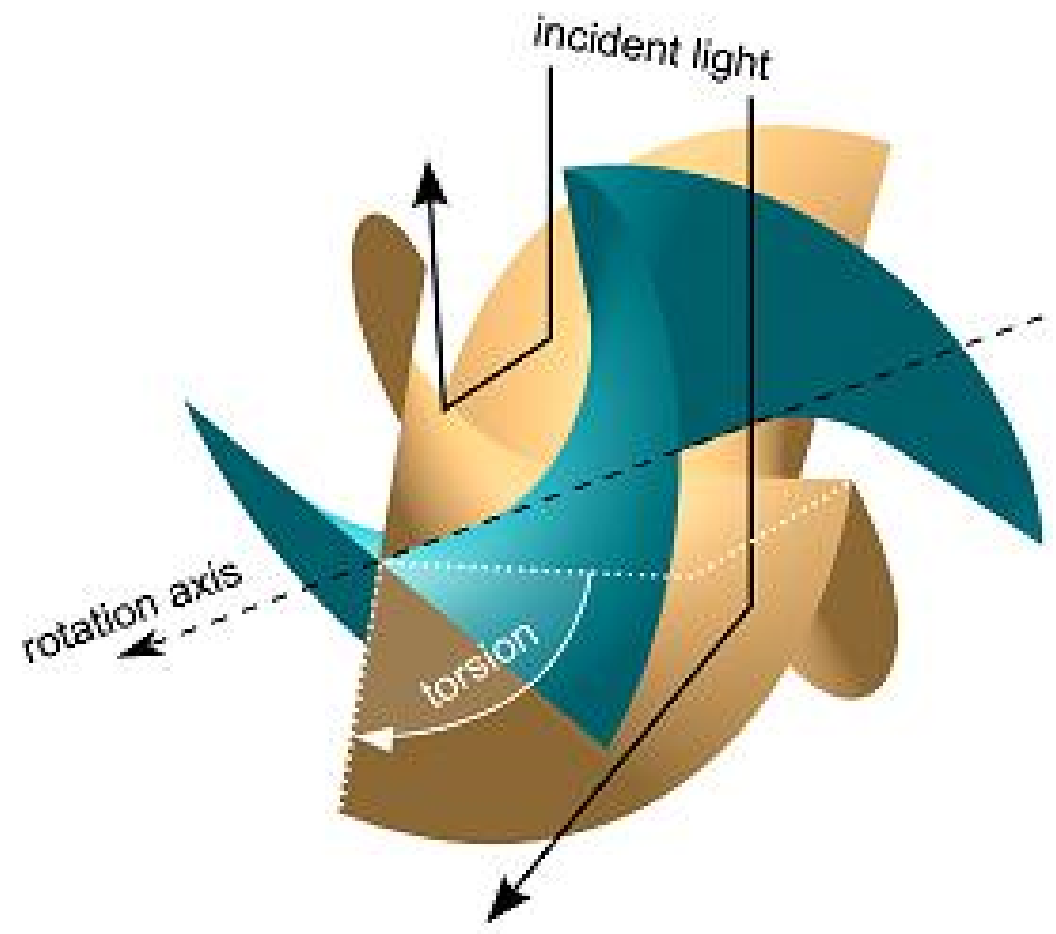

14. ábra A szimulációban használt 3-dimenziós guriga alakja.

\subsubsection{A folyamatos forgás feltétele}

A szimulációk célja annak vizsgálata volt, hogy mekkora forgatónyomaték hat a struktúrára a fénnyel történő kölcsönhatás során a különböző orientációkban. Minden egyes orientáció esetén a 
forgatónyomatékot meghatározva el lehet dönteni, hogy az adott alakú struktúra képes-e a folyamatos forgásra. Ennek vizsgálatakor figyelembe kell venni, hogy az alacsony Reynoldsszámok tartományában a tehetetlenség elhanyagolható. Emiatt a pillanatnyi sebesség a struktúrára ható erővel, a pillanatnyi szögsebesség pedig mindig az éppen a struktúrára ható forgatónyomatékkal lesz arányos.

\section{E feltételek mellett a folyamatos forgás feltétele az, hogy a forgatónyomaték a teljes}

\section{körülfordulás során egyik orientációban sem lehet 0.}

Abban az esetben, ha a forgatónyomaték értéke a forgás során egyszer is nulla értéket vesz fel, a forgás azonnal leáll. Ez két esetben fordulhat elő: a teljes körülforgás során a forgatónyomaték i) előjelet vált úgy, hogy a forgatónyomaték-orientáció függvény meredeksége a 0 helyen negatív, ekkor stabil egyensúlyi helyzet alakul ki; ii) ha a forgatónyomaték-orientáció függvény meredeksége a 0 helyen pozitív, illetve lokális minimuma/maximuma van, ahol az értéke nulla, ekkor az egyensúlyi helyzet instabil.

\subsubsection{Prizmaszerü gurigák szimulált forgása}

A prizmaszerü struktúrák szimulációja során mind az alak, mind az optikai tulajdonságok változtatva voltak. A struktúrák alakja forgásszimmetrikus volt, a különböző esetekben a tengelyből kiinduló úgynevezett „karok” számában és alakjában volt különbség. Ennek megfelelően a karok száma 3 és 8 között volt változtatva, míg az alakjuk lehetett egyenes, vagy görbült, ahogy a 15. ábrán is megfigyelhető. Az optikai viselkedést tekintve mindhárom esetet (teljesen fényvisszaverő, átlátszó és nem fényelnyelő, fényelnyelő) megvizsgáltuk.

\subsubsection{Teljesen fényvisszaverö eset}

A teljesen fényvisszaverő és átlátszó esetre a számolt forgatónyomatékot a 15. ábrán a képek alatti grafikonokon látjuk. A forgatónyomaték értéke (a forgásszimmetriának megfelelően) periodikusan változik, és egy teljes körülfordulás során annyi periódus jelenik meg, ahány karja van a struktúrának. A szimulált esetekre általánosan igaz, hogy a teljes körülforgás során a forgatónyomaték pozitív és negatív értékeket is felvesz. Ez az eredmény a stabil forgás 
szempontjából azt jelenti, hogy a szimulációkban vizsgált prizmaszerű teljesen fényvisszaverő gurigák nem képesek a folyamatos forgásra, hiszen a minimálfeltétel sérül. Egy körülfordulás során kétszer annyi orientáció van, ahol a forgás csapdázódik, mint ahány karja van a gurigának.
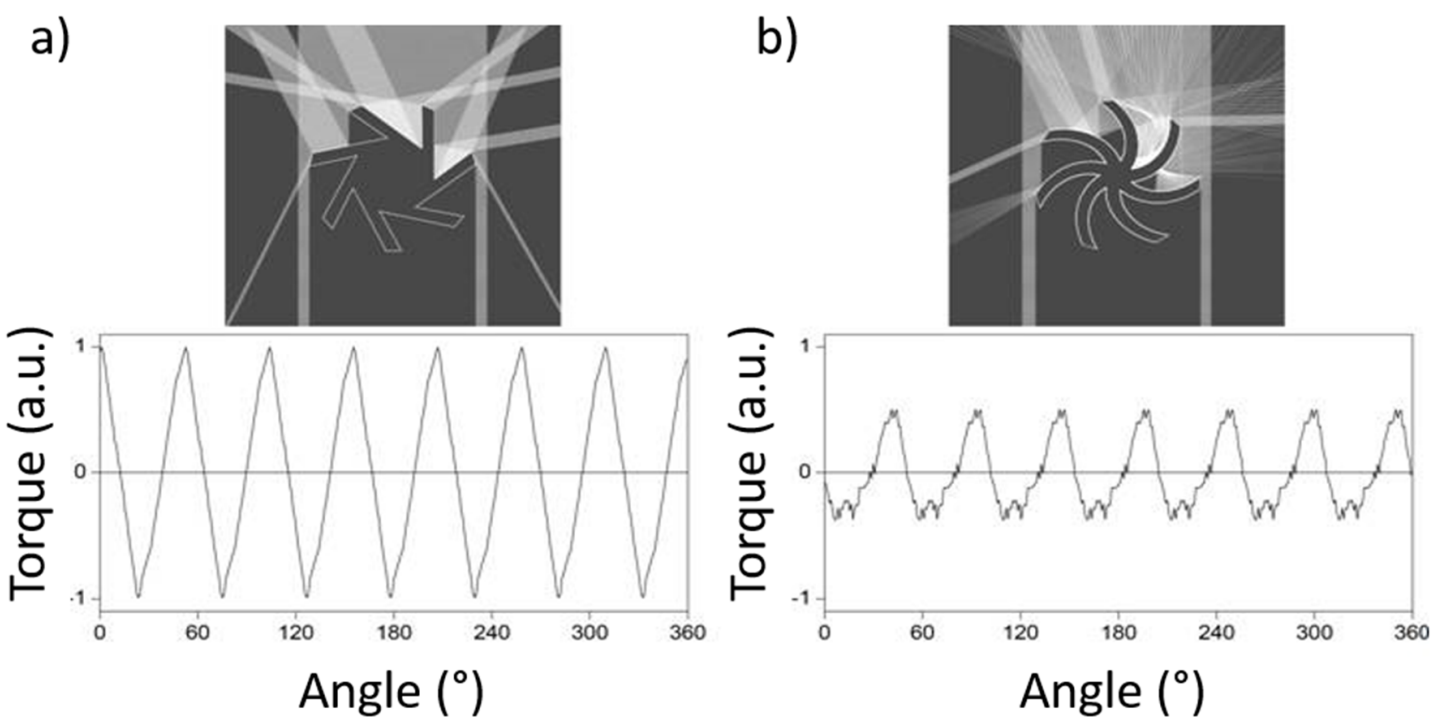

15. ábra Teljesen fényvisszaverő struktúra esetén a sugármenetek, és a hozzátartozó nyomatékok.

\subsubsection{2 Átlátszó, és nem fényelnyelö eset}

Az átlátszó, és nem fényelnyelő prizmaszerü struktúrák hasonlóan viselkednek, mint a teljesen fényvisszaverő struktúrák, mint ahogy a 16. ábrán is megfigyelhető. A forgatónyomaték értéke periodikusan változik, és egy teljes körülfordulás során pozitív és negatív értékeket is felvesz. Ebben az esetben is igaz, hogy az átlátszó prizmaszerü gurigák nem képesek a folyamatos forgásra, hiszen sérül a minimálfeltétel. 

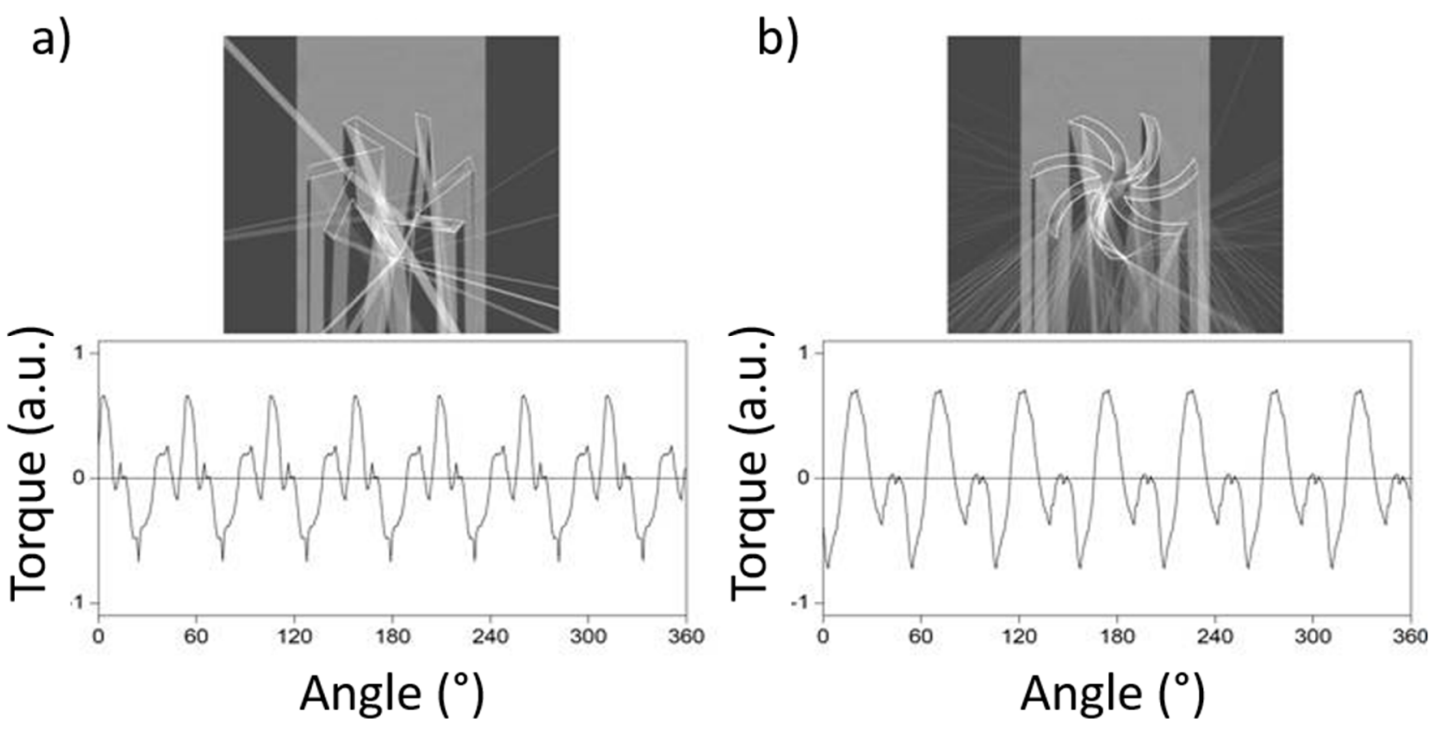

16. ábra Nem fényelnyelő struktúra esetén a sugármenetek, és a hozzátartozó nyomatékok.

Bár csak korlátozott számú szimuláció elvégzésére volt lehetőség, a szimulációk során nem volt olyan 2 dimenziós struktúra, amelynél teljesült volna a stabil forgás feltétele. Ebből a tapasztalatból kiindulva felmerül, hogy általánosan is igaz lehet az állítás, hogy veszteségmentes esetben a prizmaszerü struktúrák a forgástengelyükre merőleges homogén megvilágítás hatására nem képesek folyamatos forgásra. Ennek az állításnak az általános bizonyítását a 6.3. fejezetben fogom megmutatni.

Megjegyzem, hogy az átlászó, illetve a fényvisszaverő struktúrák esetén még az is fennáll, hogy a forgatónyomatéknak egy teljes körülfordulásra vett integrálja pontosan 0 .

\subsubsection{Fényelnyelö struktúrák}

Jelentősen eltérő viselkedés adódik abban az esetben, ha a struktúráknak van fényelnyelése, ahogy az a 17. ábrán is megfigyelhető, ekkor ugyanis elérhető az az állapot, amikor a forgatónyomaték mindig különbözik 0 -tól és nem vált előjelet, tehát a struktúra képes a folyamatos forgásra. Minden grafikonon három görbe figyelhető meg, amelyek az egy teljes körülfordulás során kifejtett nyomaték maximumát (felső), minimumát (alsó), illetve az átlagos nyomatékot (középső) mutatják az abszorpció függvényében. A kék mező jelzi azt a tartományt, ahol teljesül a folyamatos forgás feltétele. A három görbe viselkedésében lényeges eltérést figyelhetünk meg a páros és páratlan 
számú karok esetén. Amennyiben a karok száma páros az abszorpció növekedésével a három görbe 0-hoz tart (1-es abszorpció esetén egyik orientációban sincs forgató nyomaték, hiszen a maximum és a minimum is 0 ), szemben a páratlan számú kar esetével, ahol a három görbe soha „nem találkozik". Ez a fajta viselkedés abból adódik, hogy páros karok és maximális abszorpció esetén nem számít a rendszer alakja, csak annak vetülete ami a forgástengelyre nézve minden orientációban szimmetrikus lesz.

Azonban meg kell jegyezni, hogy a fenti eredmények egy kvalitatív jellemzést adnak az fényelnyelő esetről és csak a várható trendeket mutatják be, hiszen a görbék lefutása erősen alakfüggő lehet, és a szimulációk csupán néhány kitűntetett alakra lettek elvégezve.
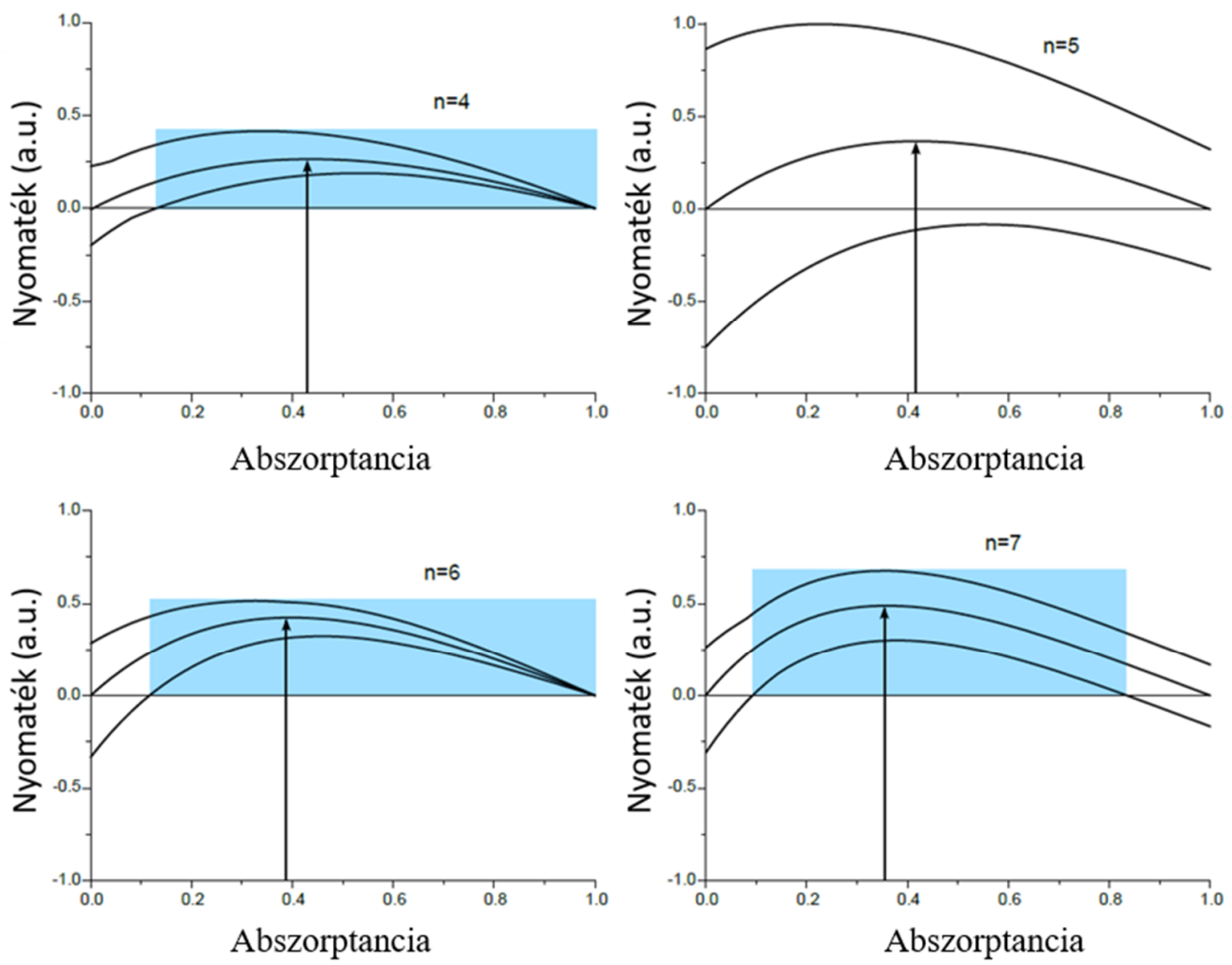

17. ábra Rotorra kifejtett nyomaték minimuma, maximuma és átlagos értéke az abszorptancia és a karok számának függvényében. Abban az esetben valósul meg folyamatos forgás, ha egy teljes körülfordulás alatt nem vált előjelet a nyomaték (ezt a tartományt a kék mező jelzi). 


\subsubsection{3-dimenziós fényvisszaverö gurigák szimulált forgása}

A 18.a) ábrán az látható, hogy a szimulációkban hogyan változik a forgatónyomaték különböző torziós szögek esetén az orientáció szögének függvényében. Tekintve, hogy a szimulációk 4-karú struktúrára vonatkoznak (amivel a kísérleteimet is elvégeztem), az orientációt a struktúra szimmetriájának megfelelően elegendő volt $0^{\circ}$ és $90^{\circ}$ fok között vizsgálni. Az figyelhető meg, hogy $60^{\circ}$-os torzió mellett, illetve az alatt van olyan orientáció, amelynél a forgatónyomaték 0 lesz, illetve előjelet vált. $90^{\circ}$-nál a nyomaték értéke minden orientációra nagyobb lesz, mint 0 és folyamatos forgásra lesz képes a guriga, illetve ezen torziós szög felett már tetszőleges érték esetén olyan guriga kapható, ami folyamatos forgásra képes.
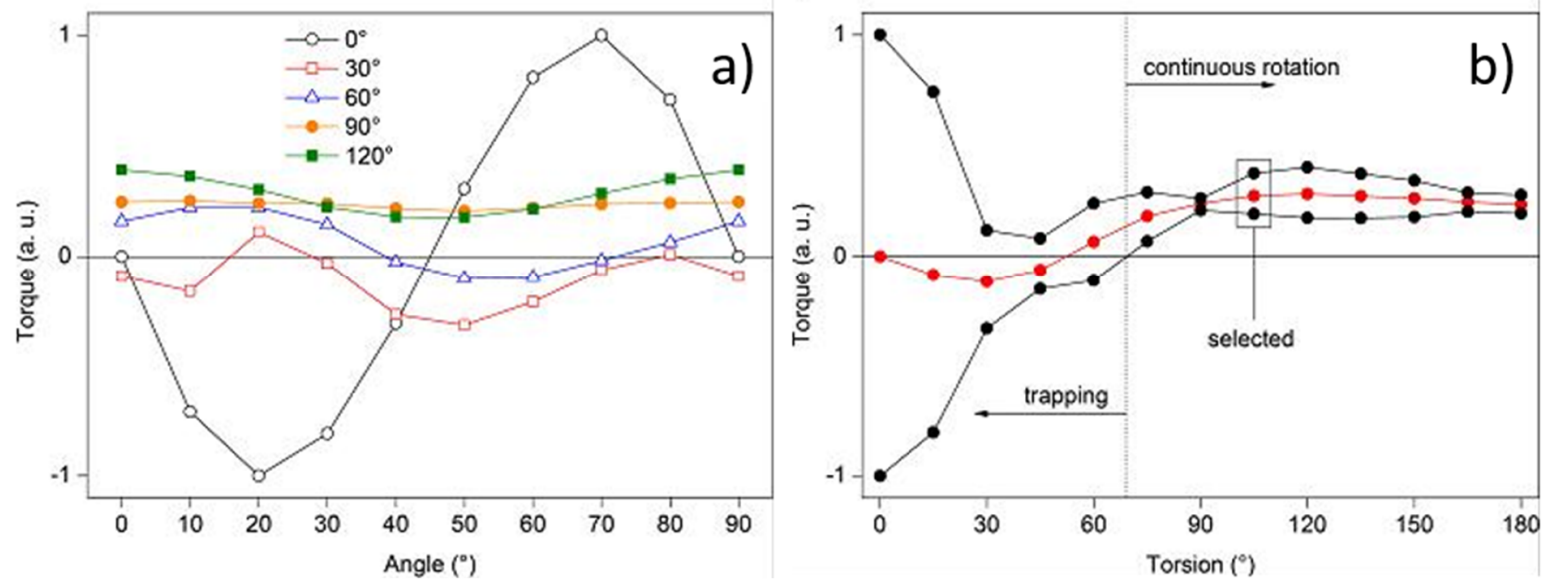

18. ábra Egy 4-karú guriga esetén a) a szimulációban kapott nyomaték a guriga orientációja függvényében különböző torzió szögek esetén, illetve b) a nyomaték maximális (felső görbe), minimális (alsó görbe) és átlagos (piros görbe) értéke a torziószögek függvényében. A bekeretezett rész mutatja a kísérletekben alkalmazott értéket.

A 18.b) ábra a torziós szög függvényében mutatja az összes orientációhoz tartozó forgatónyomatékok közül a maximális értéket (felső), a minimális értéket (alsó) és azok átlagos értékét (piros). Megfigyelhető, hogy a torzió szög függvényében van egy határszög kb. $70^{\circ}$-nál, ami alatt a nyomatéknak még vannak zérus helyei, így a struktúra folyamatos forgásra nem képes. Ezzel szemben $70^{\circ}$ felett a forgató nyomatéknak már nincsenek zérus helyei, és ennek megfelelően bármely esetben képes a folyamatos forgásra. 


\section{Kísérleti körülmények és vizsgálati módszerek}

A disszertációban leírt munka egy kutatócsoport által valósult meg, a teljes folyamat lépéseit a csoport minden tagja figyelemmel kísérte. Ezen túl az egyes munkafázisokat különböző kutatók határozták meg. E munkamegosztásnak megfelelően az egyes struktúrák elkészítése, illetve a minták előkészítése nem az én feladatom volt. Az erre vonatkozó szakaszokban leírt anyag nem tekinthető az én munkámnak, de a tartalom teljessége érdekében szükség van a beiktatására.

\subsection{Struktúrák előállítása}

A kísérleteimben felhasznált összes mikrostruktúra kétfotonos polimerizációval készült és a különböző struktúrák polimerizációja során ugyanazon lépéseket kellett végrehajtani. A fotopolimerizáció anyaga az SU8 (Michrochem, Newton, MA, USA) fotopolimer volt: ez igen nagy mechanikai stabilitású mikrostruktúrákat eredményez.

A mikrostruktúrák polimerizációja $150 \mu \mathrm{m}$ vastag fedőlemezen történt (Menzel-Glaser, Németország). Az üvegeket előzetesen legalább egy éjszakán keresztül 70\%-os krómkénsavban tisztítottuk, ezt követően desztillált vízzel leöblítettük, illetve nitrogén gázzal teljesen megszárítottuk. A tisztítás utolsó lépéseként a fedölemezek felszíne 15 percen keresztül oxigén plazmával lett kezelve, aminek célja, hogy minden szerves vegyületet eloxidáljon a hordozó felszínéről. A tisztított üvegek felületére 16-30 $\mu \mathrm{m}$ vastag SU8 fotopolimer réteget vittünk fel (SU8 2007 típus) spin-coat technikával (P-6708 spincoater, Specialty Coating Systems, USA). A mikrostruktúrák kialakítása során ezt a vékonyréteget világítottuk meg.

A kétfotonos polimerizációhoz egy 780nm-es hullámhosszon működő femtoszekundumos lézert (C-Fiber A 780, Menlo Systems, Germany) alkalmaztunk, ennek impulzushossza 100fs, impulzusismétlési frekvenciája 100MHz volt. A nyaláb átlagos teljesítménye a fókuszáló objektív hátoldali apertúrája előtt mérve $5 \mathrm{~mW}$ volt. A polimerizáló nyalábot egy Zeiss Axiovert 40 típusú mikroszkópba vezettük be az epifluoreszcens csatlakozáson keresztül, a nyaláb fókuszálását egy 100X nagyítású nagy numerikus apertúrájú olajimmerziós objektív (Zeiss Achroplan, NA = 1.25) 
végezte. A polimerizáció során a mintát egy 3 dimenziós piezo pozicionáló (Physik Instrumente GmbH, Karlsruhe, Germany) mozgatta, ez $100 \mu \mathrm{m}$-es eltolást nanométeres pontossággal volt képes végrehajtani. A fotopolimerizációt számítógép vezérelte egy Labview szoftver segítségével. A megvilágítást követően minden minta legalább 10 percen keresztül $95^{\circ} \mathrm{C}$-on utólagos hőkezelést kapott, majd SU8 előhívó folyadékba került 3-szor 10 percre, és végül alkoholba 5 percre. A fenti rendszer az optikai tengelyre merőlegesen $100 \mathrm{~nm}$-es, míg az optikai tengely mentén $500 \mathrm{~nm}$-es feloldást tett lehetővé.
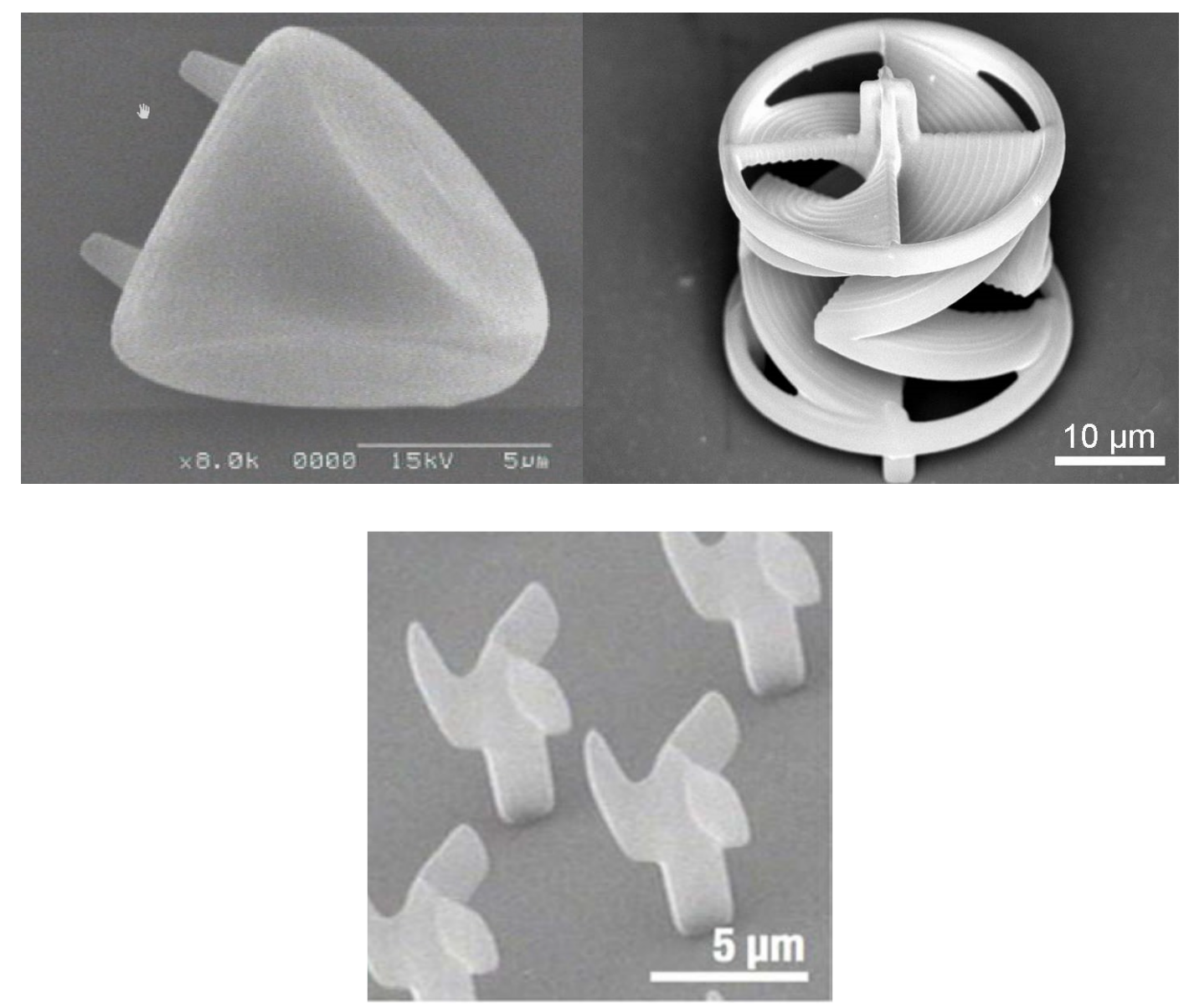

19. ábra Elektronmikroszkóppal készített felvételek a) ékről, b) gurigáról, c) mikrorotorokról.

A 19. ábrán bemutatom a kísérleteimben alkalmazott kétfotonos polimerizáció útján készült struktúrákat: a) ékek, b) gurigák és c) mikrorotorok. Minden mikrostruktúra esetén megfigyelhetö, hogy az egyik oldalon apró nyúlványok láthatók: ez az alkalmazott fotopolimerizációs eljárás következménye: a fotopolimerizációt úgy végeztük, hogy a struktúrák az üvegfelületre legyenek 
rögzítve a gyártás során, ellenkező esetben a mikroszkopikus testek elvesztek. Az apró nyúlványok feladata, hogy egyrészt rögzítsék a struktúrákat az üvegfelülethez, másrészt eltartsák őket attól. Mivel a struktúrák hordozótól való eltávolítása mechanikai úton történt, a távtartók révén csak kis területen kapcsolódott a hordozóhoz és könnyebben eltávolíthatók voltak a felszíntől a struktúra sérülése nélkül.

\subsection{A mikrocsatornák típusai}

A munkám során két különböző típusú mikrocsatornát használtam. Az egyszerüség kedvéért ebben a fejezetben ismertetem a csatornák típusait, és a dolgozatomban úgy fogok rájuk hivatkozni, mint I-es, vagy II-es típusú mikrocsatorna.

I-es típusú mikrocsatorna: A mikrocsatorna hordozójaként mikroszkóp fedőlemezt használtunk. Oldalfalait két párhuzamos fedőlemez alkotta, melyeket fényre keményedő ragasztóval (Norland) rögzítettünk a hordozóra, illetve a csatornát felülről lezáró fedőlemezhez. A csatorna belső magassága így kb. $200 \mu \mathrm{m}$ volt. A csatornát általában vízzel töltöttük meg, amibe Tween20 detergenst is tettünk, hogy ne ragadjanak le a struktúrák. A csatornát mindkét végén immerziós olajjal zártam le, ami megakadályozta, hogy a csatornából elpárologjon a víz, aminek köszönhetően akár több napig is használható a minta. Egy I-es típusú csatorna elvi rajzát a 20.a) ábra mutatja.
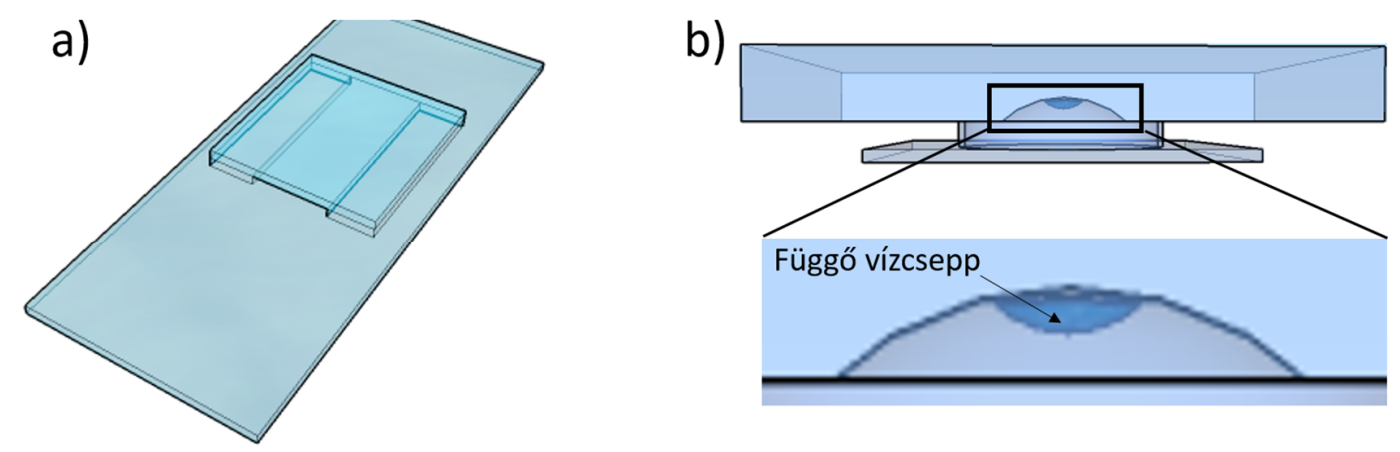

20. ábra A kísérleteimben használt a) I-es felülnézetből és b) II-es típusú mikrocsatorna oldalnézetben. 
II-es típusú mikrocsatorna: A csatorna hordozójaként mélyített mintatartó résszel rendelkező mikroszkóp tárgylemezt (cavity slide) alkalmaztunk. Ennek közepén egy mélyedés volt kialakítva, ebbe a mélyedésbe tettünk egy vízcseppet $(\sim 5 \mu 1)$, és ebbe a cseppbe kerültek bele a mikrostruktúrák. A kísérlet során a hordozót lefelé fordítottam, ezáltal egy függő vízcsepp alakul ki, és ekkor a gravitáció hatására a vízcsepp alján - a víz levegő határfelületnél - gyültek össze a struktúrák. Ennek az elrendezésnek a célja a határfelületen fellépő súrlódás csökkentése volt, ami igen jelentős lehet a víz-üveg határfelületen, míg a víz-levegő esetben a súrlódás nem okozott problémát. A II-es típusú csatorna a 20.b) ábrán figyelhető meg. A függő cseppes kísérleteknél sajnos gyakran előfordult, hogy a görbült üveg/folyadék felületen keresztül történő megfigyelés miatt a struktúrák alakja torzult a leképezés során.

\section{3. Ékek és gurigák előkészítése}

\subsection{1. Ékek elökészitése}

Az ékek alakjának megtervezésénél fontos szempont volt, hogy amikor behelyezzük öket a mikrocsatornába, minél nagyobb legyen a valószínúsége, hogy az ne valamelyik oldal, hanem az egyik éket alkotó lapjára essen. Ennek érdekében olyan struktúrát terveztünk, amely oldalról nézve szimmetrikus, mégpedig egy egyenlőszárú háromszög. A háromszög szárai alkotják az ék lapjait, amelyek a fényt visszaverik, illetve amelyen az ék csúszik. Ezek egymással $40^{\circ}$-os szöget, míg az alaplappal $70^{\circ}$-os szöget zárnak be. Ezen felül az ékek alapja és oldalai enyhén le lettek kerekítve, hogy ha esetleg ezen lapjaikra esnek, akkor ne álljanak meg stabilan és az éket alkotó lapok egyikére billenjenek át. Az ékek egyenlőszárú oldala $12 \mu \mathrm{m}$ hosszú, amikor egyik lapján fekszik, akkor a magassága $10 \mu \mathrm{m}$, illetve $9 \mu \mathrm{m}$ a szélessége, ahogy a 21 . ábra is mutatja.

Abból a célból, hogy az ékek felülete jó fényvisszaverő legyen, az előhívást követően a felületüket DC porlasztás (Emitech K975X, UK) technikával először $5 \mathrm{~nm}$ krómmal, majd $200 \mathrm{~nm}$ arannyal vontuk be. A kísérleteim elvégzésére az I-es és II-es típusú mikrocsatornákat használtam. 


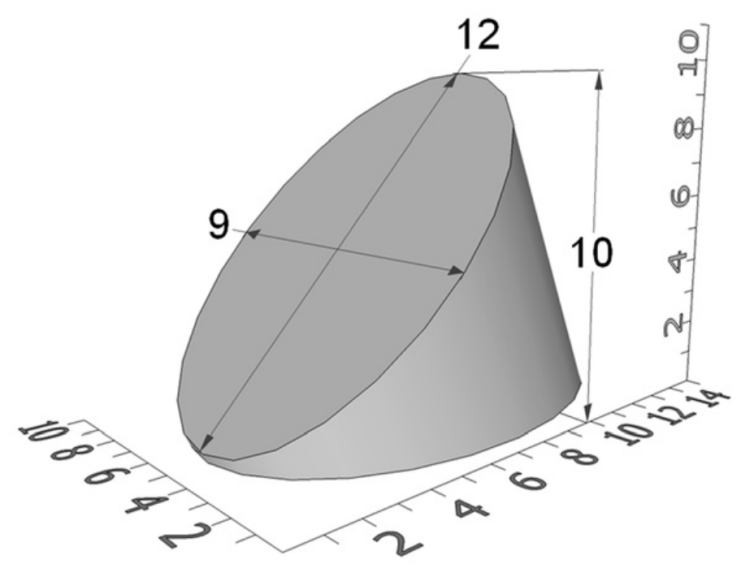

21. ábra Az ékek geometriája.

Az ékek mozgását azok pozíciójával, illetve orientációjával jellemeztem. Bár az egyes mintákban nagyszámú ék volt található (100-200), általában olyan felvételeket vizsgáltam, ahol egyetlen ék a többitől el volt szeparálva, így mozgását a többi ék mozgása nem befolyásolta. A dolgozatomban bemutatott eredményeket kb. 50 ékhez tartozó pálya vizsgálatával kaptam.

\subsubsection{Gurigák elökészítése}

A gurigák sugara és magassága $\mathrm{kb} .35 \mu \mathrm{m}$ volt. A gurigák végein a tengelyt kissé meghosszabbítottuk, ez megakadályozta azt, hogy a gurigák a tengelyükkel a gördülő felületre merőleges orientációt vegyenek fel. A csak az egyik oldalon található polimerizációs segéd csonkok a guriga orientációjának azonosítását is lehetővé tették. A gurigák két végükön egy-egy gyürüvel lettek kiegészítve, ezek szerepe a folyamatos és sima gördülés biztosítása volt.

A polimerizációt követően a gurigák felületét tükrözővé tettük: a felületére $5 \mathrm{~nm}$ vastag króm, majd 200nm vastag aranyréteget vittünk DC porlasztás technikával (Emitech K975X, UK). A bonyolult alakú struktúra teljes beborítását úgy értük el, hogy a párologtatóba egy forgó mintatartót szereltünk, ez biztosította, hogy minden orientációban jusson fém a felületre. A kísérleteim elvégzésére az I-es típusú mikrocsatornákat használtam.

A gurigák mozgásának vizsgálata során az ékekhez hasonlóan jártam el, általában olyan felvételeket vizsgáltam, ahol egyetlen guriga volt látható, így a mozgását a többi guriga mozgása nem befolyásolta. A kiértékelések során kb. 15 mozgás pályáját figyeltem meg. A pálya minden 
pontján meghatároztam a pillanatnyi sebesség nagyságát és irányát, illetve a guriga orientációját. Ezen kívül minden ponthoz hozzárendeltem még a lokális intenzitást, és annak gradiensét (irányát és nagyságát). Az intenzitás meghatározásánál a kísérletileg mért adatokra illesztett Gauss függvényeket vettem alapul.

\subsection{3. Ékek és gurigák megfigyelésére használt kísérleti elrendezés}

Az ékek és gurigák mozgásának vizsgálatát egy Axio Observer Al típusú invertált mikroszkóp segítségével végeztem el. Mindkét mikrostruktúra megvilágítására ugyanazt a lézert, egy 1070 nm-es hullámhosszon működő Ytterbium szállézer (IPG-YLM-10, IPG Photonics) fényét használtam, melynek maximális teljesítménye $10 \mathrm{~W}$ volt. Az ékek és gurigák megvilágítására két eltérö elrendezést alkalmaztam. Ezek között a leglényegesebb különbség az volt, hogy az ékek csak egy irányból, mégpedig a kondenzor lencsén keresztül voltak megvilágítva (felső ág), addig a gurigák két irányból, a felső ágon túl a megfigyelésre használt objektíven keresztül is meg voltak világítva (alsó ág). A kettős megvilágításra azért volt szükség, mert egyetlen nyaláb alkalmazásával nem tudtunk forgást előidézni. A teljes szimuláció is megmutatta, hogy a fény forgató hatása (forgatónyomatéka) kicsi ahhoz az erőhöz képest, amely a megvilágítás irányában nyomja a testet: ha felülről világítjuk, olyan erővel szorítja a fény a gurigát a felülethez, hogy nem képes gördülni. Ha kizárólag csak alulról világítjuk meg, a fény ellöki a testet. Tekintve, hogy a forgás előidézése szempontjából az alsó illetve felső megvilágítás ekvivalens, a probléma a kettős megvilágítással oldható meg. Ekkor a merőleges nyomó hatás kiegyenlítődik, a forgató hatás pedig összeadódik.

A felsö ágat a mikroszkóp saját felső fényforrásának alumínium vázához rögzített tükörtartó illetve abban elhelyezett aranyozott üveglap - segítségével csatoltam be a mikroszkóp optikai tengelyére. Az aranyozott üveglap az infravörös fény közel 50\%-át visszaverte, és a látható tartományban is elegendő fényt engedett át ahhoz, hogy a mikroszkóp saját fényforrását a minta megfigyelésére használni lehessen. 


\subsubsection{A megvilágító fényforrás karakterizálása}

Az ékek meghajtása során a meghajtó fényforrás által kivilágított köralakú terület átmérôjét kb. 100-300 $\mu \mathrm{m}$ között változtattam, amit a megvilágító sugarak kamerán kapott képe (22.a) ábra) alapján becsültem meg a képre illesztett Gauss függvény segítségével (22.b) ábra) (a nyaláb méretet azzal a távolsággal definiáltam, ahol a maximális intenzitás az $1 / e^{2}$ részére csökken). A nyaláb teljesítményét $1 \mathrm{~W}$ és $4 \mathrm{~W}$ között változtattam. A megvilágító nyaláb méretét az ékek méretével összevetve közel igaz, hogy mivel sokkal nagyobb a nyalábméret, a megvilágítás az ékek felületén lokálisan homogénnek tekinthető.
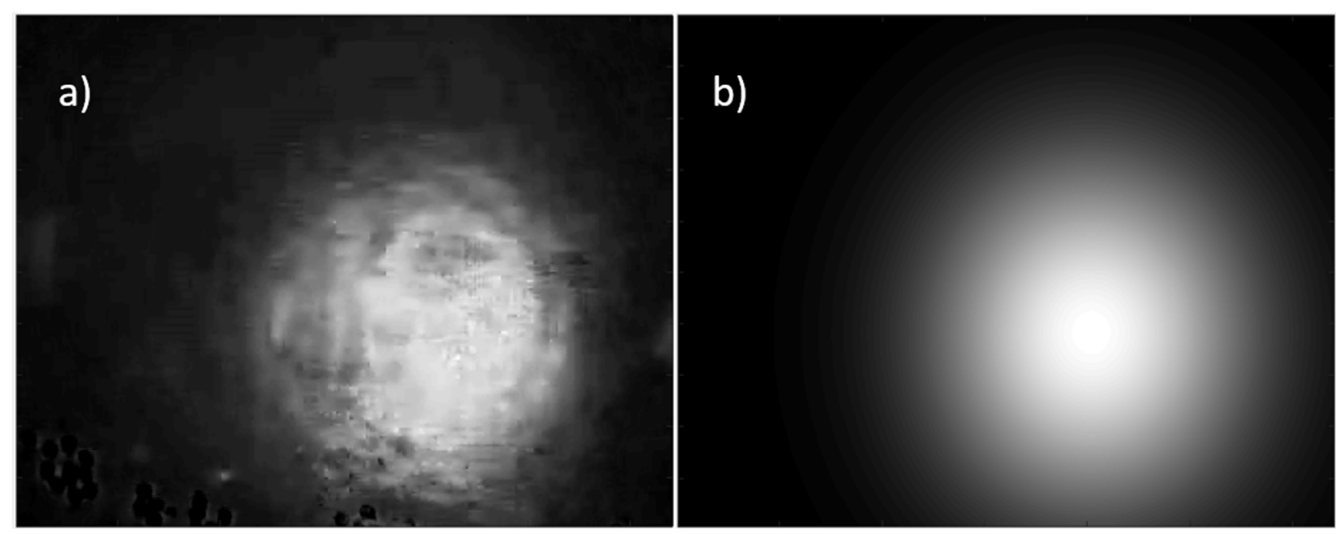

22. ábra a) A megvilágításra használt fényforrás képe, illetve b) az erre illesztett Gauss függvény.

A gurigák meghajtása során a kilépő lézernyaláb fényét egy $\lambda / 2$ lemez és egy polarizációs nyalábosztó kocka segítségével két nyalábra osztottam. Ennek a nyalábosztásnak a legfőbb előnye, hogy a két ág intenzitásarányának finomhangolását tette lehetővé, precízen be lehetett állítani ennek optimális értékét. Az egyik nyaláb a mikroszkóp oldalsó bemeneti csatlakozó, illetve a megfigyelésre is használt 0.25 numerikus apertúrájú objektíven keresztül (alsó ág) jutott a mintatérbe. A másik nyalábot a kondenzorlencsén keresztül (felső ág) vezettem a mintatérbe. Az alsó ágban a mikroszkópba becsatolás előtt egy lencsét is behelyeztem az optikai útba (ezen felül számolni kellett a tubuslencsével is), melynek célja az volt, hogy az objektíven áthaladó nyaláb divergenciáját és méretét állítani lehessen. Fontos volt, hogy lehetőleg nagy tartomány legyen kivilágítva, de minél kevésbé legyen széttartó a nyaláb. A kondenzor lencse pozícióját (ezzel együtt a nyaláb méretét) úgy állítottam be, hogy a mintatér jelentős részét kivilágítsa. Mivel a 
kondenzor lencse csupán egy igen keskeny (kb. $1 \mathrm{~mm}$ átmérőjü) nyalábbal volt kivilágítva, a nyaláb divergenciája nem volt jelentős.

A kísérletek pontos kiértékelése érdekében a felső és alsó ág fényének mintatérbeli intenzitás eloszlását is meg kellett határozni. Ebből a célból egy $50 \mu \mathrm{m}$ átmérőjü tülyukat helyeztem a minta síkjába, olyan módon, hogy az objektívvel éles képet kapjak a túlyukról. Ezt követően a motorizált tárgyasztal segítségével az optikai tengelyre merölegesen xy síkban, mindkét irányba $50 \mu \mathrm{m}$-es lépésekben mozgattam a tülyukat, miközben teljesítménymérövel mértem a rajta áthaladó teljesítményt. Mivel a kapott intenzitás eloszlások jó közelítéssel Gauss eloszlások voltak, a mérési adatokra Gauss függvényt illesztettem, ahol az illesztésből származtatott adatokat a 1. táblázat mutatja. A 23. ábrán látható hogyan helyezkedett el egymáshoz képest az alsó és felső megvilágítás, illetve a körök jelzik az egyes nyalábok méretét is.

\begin{tabular}{|c|c|c|}
\hline & Csúcsintenzitás $\left(\mathrm{W} / \mathrm{cm}^{2}\right)$ & Nyaláb sugara $\left(1 / \mathrm{e}^{2}\right)(\mu \mathrm{m})$ \\
\hline Felső ág & 249 & 132 \\
\hline Alsó ág & 304 & 164 \\
\hline
\end{tabular}

1. táblázat Az alsó és felső megvilágítás esetén a mért adatokra illesztett Gauss görbék paraméterei.

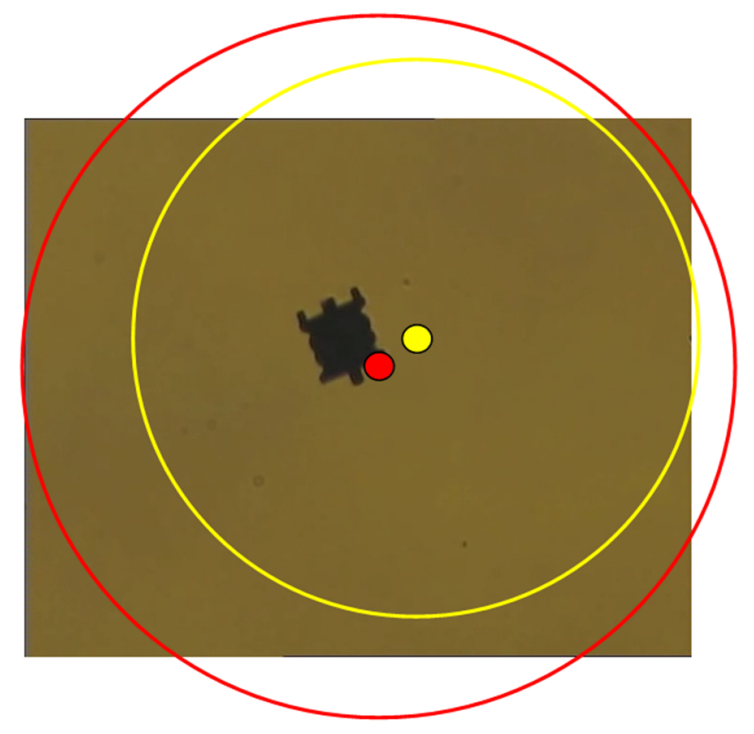

23. ábra A nyalábok elhelyezkedése egymáshoz képest egy optikai mikroszkópos felvételen. A sárga jelzi a felső ágat, míg a piros az alsó ágat. A körök jelzik a nyaláb méretét, amit a csúcsintenzitás $1 / \mathrm{e}^{2}$ részénél definiáltam. 
Mind az ék, mind a guriga kísérleteim során a struktúrák meghajtására használt fényforrás fényét a kamera előtt elhelyezett szürővel kiszürtem, mert a pontos mérést és kiértékelést zavarta volna.

\subsection{Mikrorotorok}

\subsubsection{A minták elökészítése}

A 19.c) ábrán látható, hogy a rotorok két alapvető részből állnak: a tengely és a karok. A tengely szerepe, hogy a csapda megfelelö pozícióban tartsa a rotort, a karok pedig a fénnyel kölcsönhatva a forgást keltik. A rotorok geometriájának tervezése során figyelembe kellett venni, hogy egy rotort egyetlen optikai csapda fog megtartani. Túl hosszú tengely esetén egyetlen csapda nem képes stabilizálni a forgástengelyt, ami kísérletek során jelentős billegést eredményezhet. A tapasztalatok azt mutatták, hogy $6 \mu \mathrm{m}$-es tengelyhossz esetén a rotorok még stabilan forognak, így a kísérleteim elvégzésére is ezt a tengelyhosszt választottam. A rotorok karjait sem lehetett tetszőlegesen méretezni, ugyanis a karok hosszának lényegesen rövidebbnek kell lenni a tengelynél. Ha a karok hossza túl nagy, a csapdázás szintén nem lesz stabil, illetve gyakran előfordul, hogy a karok mentén csapdázódik a rotor. Emiatt a karok hosszát kb. $2.5 \mu$ m-nek választottam. A polimerizációt követően a mikrorotorok I-es típusú mikrocsatornába kerültek.

\subsubsection{A mikrorotorok meghajtása}

A rotorok forgási sebességének és pozíciójának tetszőleges hangolására egy-egy holografikus optikai csipesszel előállított csapdát alkalmaztam. Az egyes rotorok forgási sebességét a csapdázó nyalábok intenzitása határozta meg. Az egyes nyalábok intenzitását holografikusan állítottam, olyan módon, hogy az SLM-en megjelenített hologram számolásakor az egyes nyalábokat meghatározó hologramok eltérő súlyozást kaptak. Mivel a csapdázásra használt nyalábokat egyetlen nyaláb holografikus osztásából nyertük, az egyes nyalábok intenzitásának állítása nem függetlenül, hanem a nyalábok összenergiájának átrendezésével történt. Így a sebességek arányát rendkívül finoman lehetett hangolni, rotoronként akár 0.001 relatív sebességváltozás is megvalósítható volt. 
A rotorok átlagos forgási frekvenciája kb. 6-8 Hz volt. Emellett olyan sebesség tartományt kellett beállítani, hogy biztosan áthaladjon az azonos sebességü tartományon, vagyis amelyik rotor forgása gyorsabb volt a mérés kezdetén, a mérés végén lassabb legyen. Így egy méréssorozaton belül 40-50 különböző sebességarány beállítása volt szükséges. Egy adott sebesség arányt tipikusan 10-40 s-ig tartottam (az adott mérés sorozatban ez az érték állandó volt), ezt követően újabb sebesség arányt állítottam be. A sebességek változtatása közben nem szakítottam meg a mérést, tehát a mérés is és a felvétel is folyamatos volt. A mérés során a nominális sebességarányok változtatása monoton volt. A rotorok forgásáról 100 fps képrögzítési sebességgel készültek video felvételek, hogy a rotorok forgását a kiértékelés során könnyen követni tudjuk.

Méréseimet 3 különböző rotortávolságnál végeztem el. A minimális $6 \mu$ m-es távolságtól 0.5 mikronos lépésekben haladtam $7 \mu \mathrm{m}$-ig. A legkisebb $6 \mu \mathrm{m}$-es távolságnál olyan közel voltak egymáshoz a rotorok, hogy nominálisan a rés közöttük kb. $0.5 \mu \mathrm{m}$ volt. Valójában a rés mérete nagymértékben függött a rotorok tényleges alakjától, ugyanis az előállításuk során kis eltérések felléphettek, ami befolyásolja a tényleges rotortávolságot. Másrészt az is jelentős hatással bír, hogy az optikai csipesz hogyan csapdázza rotort. Ha a rotornak van valamilyen belső struktúrája, illetve ha a csapdázó nyaláb nem tökéletes, akkor a rotort nem a szimmetria tengely mentén csapdázza, ami további eltérést eredményezhet. A fenti okok miatt nem volt célszerü $6 \mu$ m-nél közelebb helyezni egymáshoz a két rotort.

\subsection{Optikai csipesz}

A mikrorotorok csapdázására használt holografikus optikai csipesz rajzát a 24. ábra mutatja. A csapdázó lézer (IPG-YLM-10, IPG Photonics) kb. $1 \mathrm{~mm}$-es nyalábját az $L_{1} \mathrm{fl}=30 \mathrm{~mm}$ és $L_{2}$ f2 = 300 mm gyüjtőlencsepár által alkotott nyalábtágító segítségével 10-szeresen kitágítottam az SLM (PLUTO NIR, Holoeye) felszínének minél jobb kitöltése érdekében. A csapdázó fény becsatolására a mikroszkóp oldalsó csatlakozóját használtam. Ekkor a fényút egy, a mikroszkópba gyárilag beépített kicsatoló prizmán és a tubuslencsén keresztül vezet a mikroszkóp objektívhez, ami a csapdát létrehozza. Ennek megfelelően a SLM után elhelyezett $L_{3}$ lencsét (f3 $=200 \mathrm{~mm}$ ) 
úgy kellett a fényútba helyezni, hogy a mikroszkóp tubuslencséjével $L_{T}(\mathrm{f} 4=180 \mathrm{~mm})$ együtt a 4f-elrendezésnek megfelelö rendszert alkossanak.

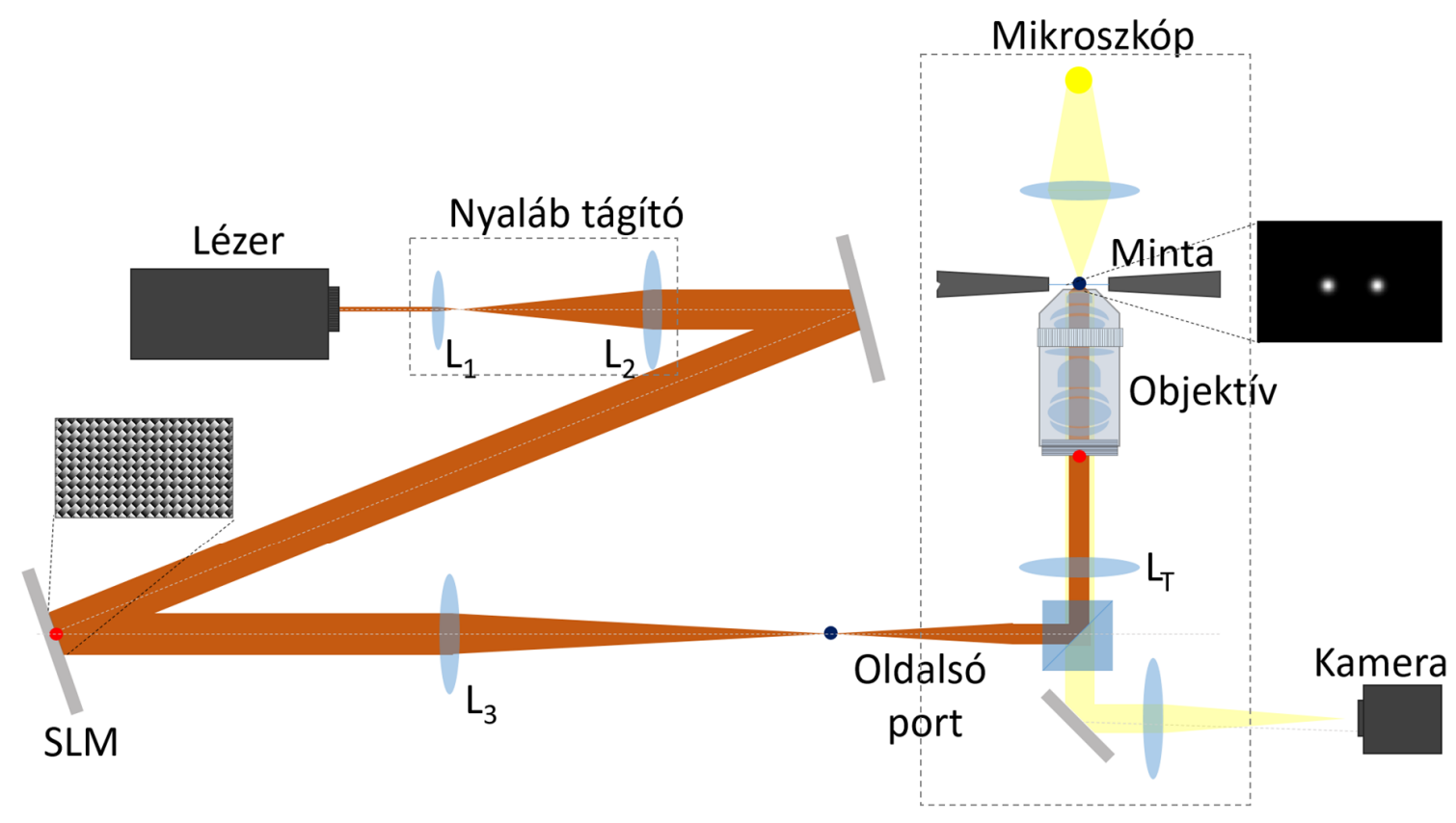

24. ábra A kísérletekben alkalmazott optikai csipeszt megvalósító optikai elrendezés elvi vázlata.

Bár az SLM teljes mérete $8.64 \mathrm{~mm}$ x $15.36 \mathrm{~mm}$, az utána elhelyezett nyalábszükítés ( $L_{3}$ és $L_{T}$ lencsepár) segítségével egy $8 \mathrm{~mm}$ átméröjű nyaláb világítja ki a mikroszkóp objektív $(7.2 \mathrm{~mm}$ átméröjü) hátsó apertúráját. Az optikai csapdák előállítására egy nagy numerikus apertúrájú víz immerziós objektívet használtam (Olympus UPlanSApo, vízimmerziós, 60X/1.2NA), amelyen keresztül a minta megfigyelése is történt. A megfigyelésre és a filmek rögzítésére GC1280 (Allied Vision Technologies Canada Inc.) típusú kamerát használtam. A kamera a mikroszkóp felső portján helyezkedett el egy $1 \mathrm{X}-4 \mathrm{X}$ nagyítást lehetővé tevő zoom optika közbeiktatásával. A mérések közben a kamera elött egy szürőt helyeztem be a fényútba, amely a csapdázó nyaláb visszaszórt sugarait kiszürte.

A két csapdázó nyaláb létrehozása és intenzitásarányának állítása az SLM-en megjelenített hologramok segítségével történt. A SLM számítógép vezérléssel, Labview környezetben megírt szoftver segítségével müködött. A szoftver valós időben számolt hologramokat jelenített meg, ahol a hologram számolást a „superpositions of prisms and lenses” [124] módszer segítségével végeztem el. Egy adott intenzitásarányhoz tartozó hologram kiszámolása kb. 1-2 s-ig tartott, ami 
a mérések elvégzése közben történt. Mivel a mérések időtartamához (10-40 s) képest elég rövid volt, így nem befolyásolta a mérést (pl.: a beállított időtartamokat).

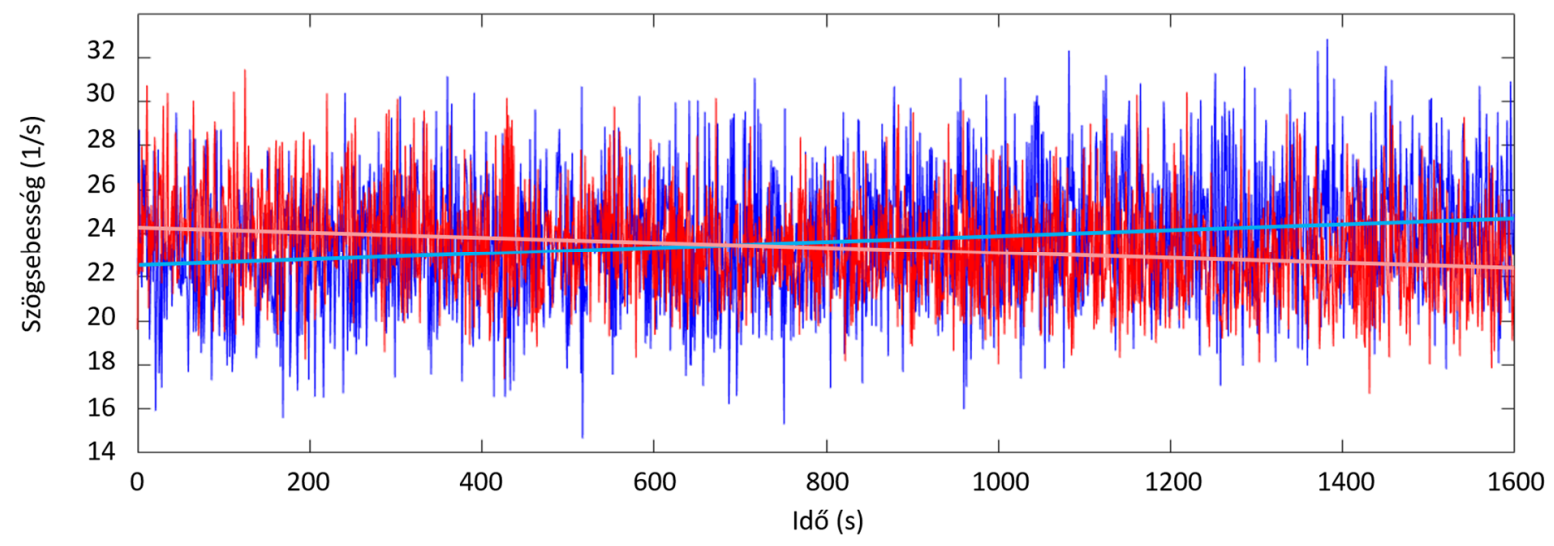

25. ábra A szögsebesség változása a csapdák intenzitás arányának változtatásával, illetve az adatokra illesztett egyenesek. A sebesség 80 lépésben változott és 20 s-on keresztül tartott meg egy adott sebességet.

A 25. ábrán a rotorok sebességének változása figyelhető meg 80 különböző intenzitásarány beállítása közben, olyan esetben, amikor a rotorok nem szinkronizálódtak. A mikrorotorok sebessége időben közel lineárisan változott, ahogy az egyes csapdákhoz tartozó hologramok súlyozását lineárisan változtattam. Az áttekinthetőség érdekében csak minden századik pontot ábrázoltam. Az ábrán bemutatott esetben a sebesség relatív változása lépésenként kb. 0.001 volt.

\subsection{1. „Superpositions of prisms and lenses”}

A csapdapozíciók állítása és az intenzitás arányok beállítása az SLM-en megjelenített hologramok segítségével történt, amit a superpositions of prisms and lenses eljárással számoltam ki [124]. Az alábbiakban röviden bemutatom a módszert.

Induljunk ki abból az esetből, hogy $m$ számú csapdát szeretnénk létrehozni a mintatérben tetszőleges választott pozícióval. A m-edik csapda helyén a komplex amplitúdót az alábbi egyenlet írja le: 


$$
\begin{gathered}
v_{m}=\frac{e^{i 2 \pi\left(2 f+z_{m}\right) / \lambda}}{i} \frac{d^{2}}{\lambda f} \sum_{j=1 \ldots N}|u| e^{i\left(\phi_{j}-\Delta_{j}^{m}\right)} \\
\Delta_{j}^{m}=\frac{\pi z_{m}}{\lambda f^{2}}\left(x_{j}^{2}+y_{j}^{2}\right)+\frac{2 \pi}{\lambda f}\left(x_{j} x_{m}+y_{j} y_{m}\right)
\end{gathered}
$$

ahol $u_{j}=|u| \exp \left(i \phi_{j}\right)$ az SLM j-edik pixeléről visszaverődő komplex amplitúdó, $\mathrm{N}$ a pixelek száma, $x_{j}, y_{j}$ az SLM pixel koordinátái, $x_{m}, y_{m}, z_{m}$ a csapda pozíciók a mintatérben a fókuszponthoz viszonyítva, $\lambda$ a csapdázó nyaláb hullámhossza, $f$ a mikroszkóp objektív fókusztávolsága, és mivel jelen kísérletekben csak két csapda van $m=1,2$ (amúgy tetszőleges számú csapda lehet). Ha feltételezzük, hogy az SLM kivilágítása homogén, és elhagyjuk az állandó szorzókat, akkor az medik csapda helyén a komplex amplitúdót az alábbi egyenlet adja:

$$
V_{m} \sim \sum_{j=1 \ldots N} \frac{1}{N} e^{i\left(\phi_{j}-\Delta_{j}^{m}\right)}
$$

ahol az m-edik csapda intenzitása $I_{m} \sim\left|V_{m}\right|^{2}$.

A (54) egyenletben a $\phi_{j}$ határozza meg, milyen hologramot kell megjeleníteni az SLM kijelzőjén, hogy az adott számú és intenzitású csapda jelenjen meg a mintatérben. A superpositions of prisms and lenses közelítésben a $\phi_{j}$ az alábbi összefüggéssel fejezhető ki:

$$
\phi_{j}=\arg \left[\sum_{m} e^{i \Delta_{j}^{m}}\right]
$$

Bár a fenti kifejezés adja az egyik legegyszerübb közelítést a hologram meghatározására, két csapda esetén igen jól alkalmazható. Abból a célból, hogy a csapdák közötti intenzitásarányokat finoman lehessen hangolni, a fenti egyenletben $w_{m}$ súlyozást alkalmaztam:

$$
\phi_{j}=\arg \left[\sum_{m} w_{m} e^{i \Delta_{j}^{m}}\right]
$$

Az egyik csapdához tartozó $w_{m}$ értéket fixen tartva a másik csapdához tartozó $w_{m}$ értéket állítva az intenzitás arányok finom állítása vált lehetővé. Az optikai csapdák közül az vált dominánssá, amelyikhez magasabb $w_{m}$ súlyozás tartozott. 


\subsection{A filmek kiértékelése}

\subsection{1. Ékek és gurigák transzlációjának és rotációjának meghatározása}

Az ékek és gurigák mozgásáról készült filmeket saját programmal értékeltem ki, amit LabVIEW (Nat. Inst. USA), vagy Matlab (The Mathwork, USA) környezetben írtam meg. A mozgások kiértékelését mindkét program esetén ugyanazon elvek alapján, két lépésben, a transzlációt és orientációt külön-külön kezelve határoztam meg.

Mivel a struktúra kontrasztosan elüt a környezetétől, célszerü volt a képkiértékelés során bináris képekkel dolgozni. Ennek megfelelően az RGB formátumú képeket szürkeskálájú, majd bináris képekké konvertáltam. Mivel a felvételeken a struktúrák képe gyakorlatilag nem változott a mozgás során, ezért a bináris képen vett optikai/tömegközéppont sem változott a struktúrához viszonyítva, így az optikai középpont követése megfelelő volt a transzláció követéséhez.

Az orientáció meghatározása során a transzláció követésénél létrehozott bináris képekből indultam ki. A felvételek első képkockáját referenciaként használtam, amelyen a struktúrák orientációja határozta meg a referenciairányt. Az orientációt ékek esetén az alakjuk által meghatározott ellipszis nagy tengelye, míg a gurigák esetén a forgástengelyének irányával azonosítottam. Minden egyes képkockán olyan eltolást alkalmaztam, hogy a referencia és próba képeken a struktúrák tömegközéppontjai egybeessenek. Ezt követően a referenciaképet kis lépésekben (jellemzően fokonként) teljesen körbeforgatva, minden elforgatáshoz kiszámoltam a referencia és próbaképek keresztkorrelációját. Egy adott próbaképhez tartozó orientációt az a szög határozta meg, amelyikhez maximális keresztkorreláció tartozott. Mivel ez az eljárás a referenciaképhez viszonyított orientációt adta meg, különböző felvételek összehasonlítása esetén figyelembe kellett venni a referenciaképen a struktúrák orientációját is.

A 26. ábrán lehet látni egy adott képkocka esetén a guriga bináris képét, illetve a forgástengelyének irányát (ami az orientációját is meghatározza). A vonal guriga közepén lévő végpontja a guriga bináris képen számolt „tömegközéppontja”. Az ábrán a sárga vonallal a guriga pillanatnyi elmozdulásának iránya is jelölve van. 


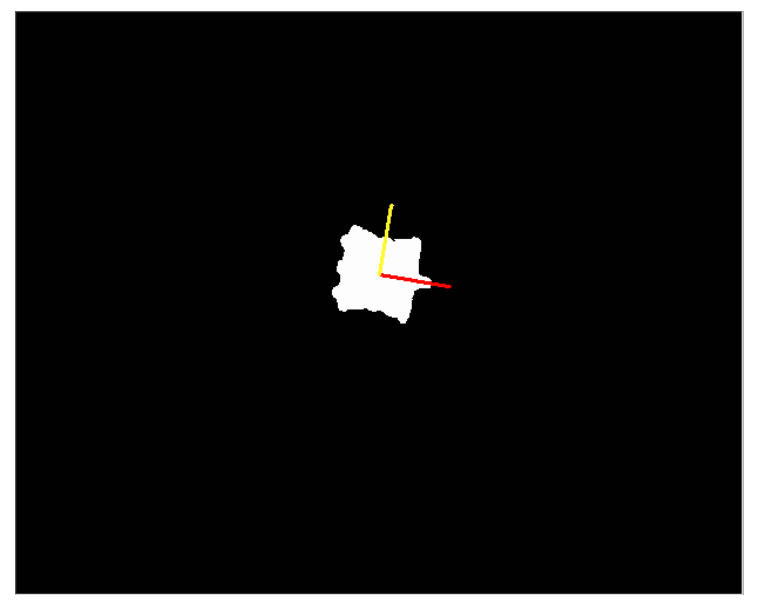

26. ábra Egy adott képkocka esetén a bináris kép, illetve a szoftver által meghatározott orientáció (piros) és elmozdulás (sárga) iránya (LabVIEW környezetben kiértékelve).

\subsubsection{Rotorok transzlációjának és orientációjának meghatározása}

A mikrorotorok mozgásáról készült videók kiértékelését Oroszi László végezte el saját C++ programnyelven írt szoftvere segítségével. A kiértékelés során az elsődleges információ a rotorok forgásának fázisa, illetve az ebböl származtatott fáziskülönbség volt. A 27. ábrán látható a fáziskülönbség meghatározásának módja. Mindkét rotor esetén az az orientáció felel meg a $0^{\circ}$-os fázisnak, amikor egyik karjuk vízszintesen és jobb oldalon helyezkedik el.

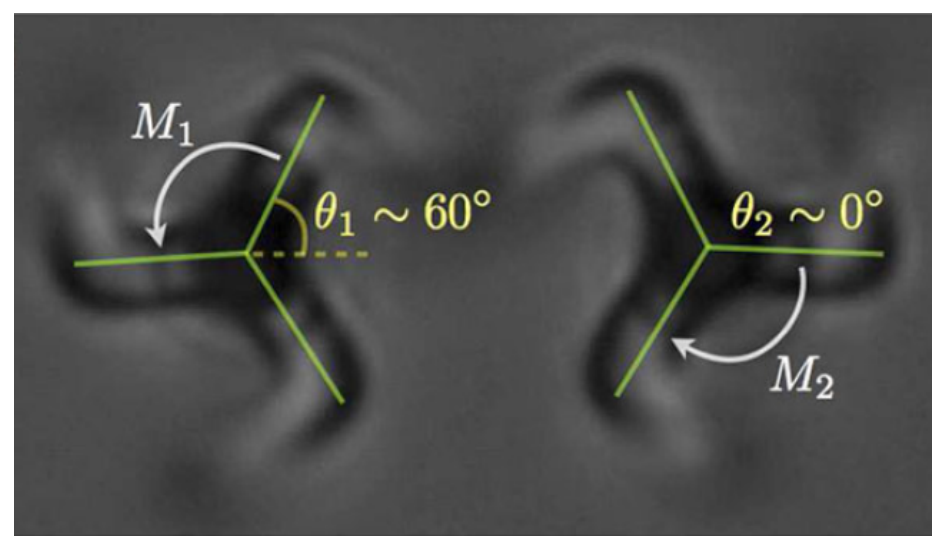

27. ábra A rotorok fázisának meghatározása. A bal oldali rotor jobbcsavar szerint, a jobb oldali rotor balcsavar szerint forog és eszerint növekszik a fázisuk. Az ábrán látható orientációban a két rotor fázisszögének különbsége $60^{\circ}$. 
Ehhez az orientációhoz képest viszonyítottam a fázist, ami az adott rotor forgásirányának megfelelöen növekszik. Mivel a rotorok ellentétes irányban forognak, emiatt a fázis növekedésének az iránya is ellentétes. A 27. ábrán a bal oldali rotor a jobbcsavar szerint, míg a jobboldali rotor balcsavar szerint forog (a forgástengely az ábra síkjából kifelé mutat). A fáziskülönbséget az így meghatározott fázisok különbsége adta (példaként a 27. ábrán a fáziskülönbség $\left.60^{\circ}\right)$. 


\section{Eredmények}

\subsection{Kísérletek az ék alakú mikrorobotokkal}

Az ékek a megvilágitás hatására mind az üveg-folyadék, mind a víz-levegő határfelületen mozgásba jöttek. Az egyes ékek mozgásának független jellemzése érdekében olyan kísérleteket végeztem el, ahol egy kiválasztott éket térben különválasztottam a többitöl, majd ennek a mozgásáról videót készítettem. Az ék kezdeti pozíciójának (a kivilágított terület közepéről, vagy a széléről indítottam a mozgást) és sebességének függvényében egy felvétel tipikusan 5-15 s-ig tartott, mivel ennyi idő kellett, hogy az ék elhagyja a kivilágított területet.

A 28. ábrán figyelhető meg több különbözö ék mozgásának a pályája levegö/víz határfelületen való mozgás esetén. Minden egyes mérés ugyanabban a mintában készült, de az egyes mérések egymástól függetlenül lettek elvégezve. A mérések egy adott ék pozicionálásával kezdődtek külső megvilágítás alkalmazása nélkül. Ezt követően elindítottam a felvételt és bekapcsoltam a megvilágító fényforrást és a mozgást rögzítettem. A különbözö felvételek között egyedül a fényforrás teljesítményét változtattam, a fényforrás helye és intenzitás-eloszlása ugyanaz maradt.

a)

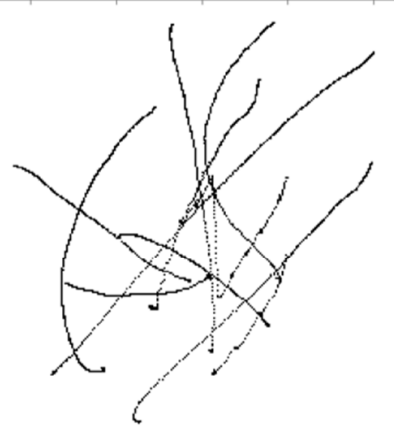

b)

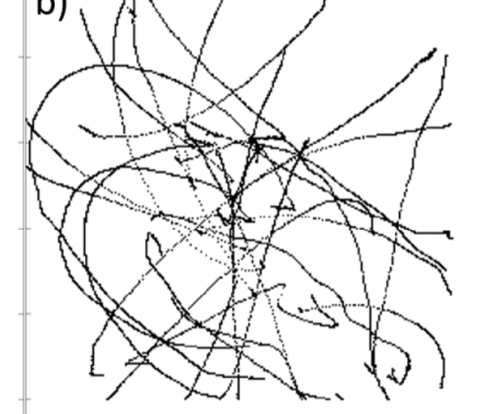

c)

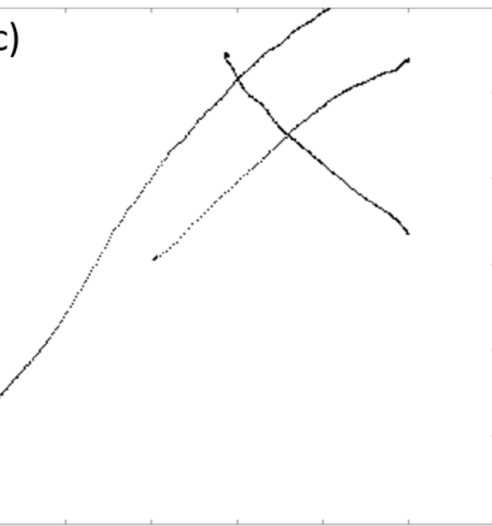

28. ábra Az ékek pályája a) $2 \mathrm{~W}$, b) $3 \mathrm{~W}$, c) 4 W teljesítményü megvilágítás esetén levegö/víz határfelületen.

Az egyes ékek mozgása véletlenszerủ, a független mérések között nincs látható kapcsolat. Gyakorlatilag tetszőleges irányú mozgás megvalósul, nincsenek kitüntetett irányok. A mozgások irányát elsősorban az ékek kezdeti orientációja határozza meg. A mozgások pályája jellemzően 
egyenes, vagy görbült és a pályákban nincsenek éles irányváltoztatások, törések. Sok pálya esetében a kezdeti és végszakaszon lehet látni fluktuáló viselkedésre utaló jeleket, aminek az az oka, hogy a mozgás rögzítése azelőtt megkezdődött, hogy a megvilágító fényforrást bekapcsoltam volna. Ennek megfelelően a kezdeti szakaszon valóban fluktuáló mozgást végeznek az ékek, ugyanígy a mérések végén, amikor már elhagyták a kivilágított tartományt.

A legtöbb trajektória keresztülhalad a legintenzívebben megvilágított tartományon is, aminek azért van jelentősége, mert azt bizonyítja, hogy a mozgást nem az intenzitás gradiens (ami vagy mindig kifelé, vagy befelé hajtaná az ékeket), vagy a megvilágítás által keltett konvekció hajtja meg. Ez utóbbi állítást az a megfigyelés is alátámasztja, hogy az ékek mellett a mintában találhatók szennyező részecskék, amelyek szemben az ékekkel a megvilágítás hatására sem mozognak (legfeljebb fluktuáció figyelhető meg).
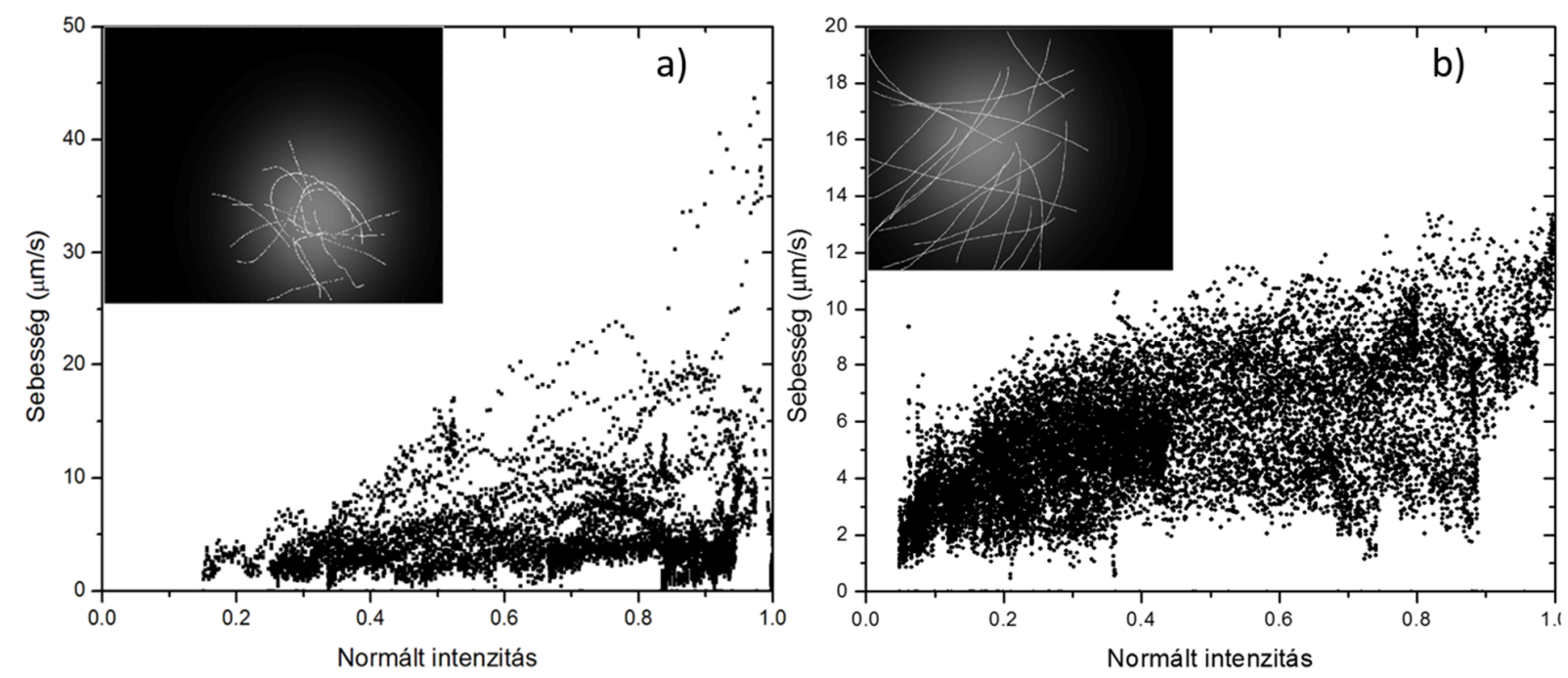

29. ábra Az ékek sebessége a normált intenzitás függvényében $3 \mathrm{~W}$ teljesítményü a) $100 \mu \mathrm{m}$ (veszteség nélküli $\left.\mathrm{I}_{\max }=1.9 \cdot 10^{4} \mathrm{~W} / \mathrm{cm}^{2}\right)$, b) $150 \mu \mathrm{m}\left(\mathrm{I}_{\max }=8.5 \cdot 10^{3} \mathrm{~W} / \mathrm{cm}^{2}\right)$ sugarú megvilágított terület esetén a levegö/víz határfelületen. A beszúrt képen a mozgások pályái láthatók a megvilágításhoz képest.

A 29. ábrán figyelhető meg az ékek sebessége a meghajtó fényforrás (csúcsintenzitással) normált intenzitásának függvényében. A maximálisan elérhető sebesség az intenzitás növekedésével közel lineárisan növekszik, aminek értéke akár az $50 \mu \mathrm{m} / \mathrm{s}$ is elérte, sőt voltak olyan mérések is, ahol a sebesség a $100 \mu \mathrm{m} / \mathrm{s}$-ot is meghaladta. A tipikus sebesség azonban néhány $10 \mu \mathrm{m} / \mathrm{s}$ volt, és 
általában a sebességet nem tartotta stabilan, hanem nagyon fluktuált. A sebesség a fluktuációja során a maximális sebesség és a $0 \mu \mathrm{m} / \mathrm{s}$ között változott. Ennek a fajta viselkedésnek számos oka lehet. Egyrészt sok olyan mérést végeztem el, ahol az ékeket nem a megvilágított tartomány széléről, hanem annak középéről indítottam. Ennek megfelelően a mérés kezdeti szakaszában, amikor még nem voltak megvilágítva, az ékek gyakorlatilag fluktuáló mozgást végeztek, amihez lényegesen alacsonyabb sebesség tartozott, mint a fénnyel hajtott állapotban. Abból a célból, hogy minél kevesebb ilyen pont legyen a mérési pontok között, a kezdeti szakaszokat kiértékelés során igyekeztem elhagyni. Másrészt a mozgást meghajtó fényforrás lokális inhomogenitása (tehát ami nem a Gauss eloszlásból származik) is okozhatja az ékek egyenetlen sebességű mozgását.

A 29. ábra vizsgálata során azt is szem előtt kell tartani, hogy a filmek kiértékelése képkockánként, tehát azonos időközönként történt. Emiatt egy trajektória azon szakaszain, ahol a sebesség alacsony volt, sűrün vannak a pontok, míg a nagy sebességü tartományokra csupán néhány pont jut. Ennek következtében az ábrázolás során az alacsony sebességű pontok túlsúlyban lesznek, míg a nagy sebességhez csupán néhány pont rendelhető. Olyan ábrázolásban, ahol a pályán egyenlő távolságonként vizsgálnánk a pontokat és a hozzájuk tartozó sebességeket, az alacsony és magas sebességű pontok eloszlása egyenletesebb lenne.

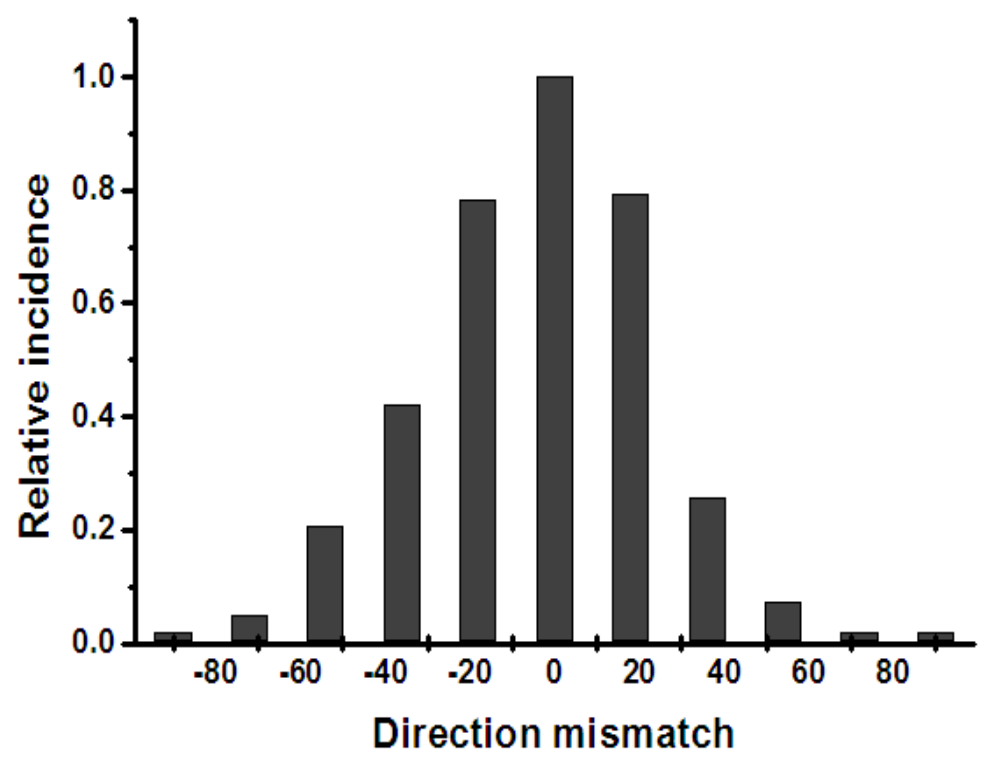

30. ábra Ékek mozgásának iránya az orientációjuktól való eltérése. 
A mozgás karakterizálása érdekében szükség van annak meghatározására, hogy a részecske orientációja milyen viszonyban van a haladás irányával. Az ékek orientációinak iránya az elnyújtott alakjuk által meghatározott ellipszis hosszabbik tengelye segítségével könnyen azonosítható. Az orientáció és a mozgás iránya (a pálya adott pontjához rendelt érintő) közötti szögeltérés a 30. ábrán figyelhető meg. Az irányok között megfigyelhető jó egyezés konzisztens azzal az elképzeléssel, hogy a mozgást a fény reflexiója hajtja meg. Az iránytól való eltérés számos jelenséggel indokolható. Ezek közül a legvalószínűbbek lehetnek például a rotációs diffúziós mozgás ami az ékek és a közeg részecskéi között fellépő kölcsönhatás miatt lép fel, vagy az ékek alakjának, illetve a megvilágítás szabálytalanságai is irányváltozáshoz vezethetnek.

Becslést lehet adni az elrendezés (fény és ékek közötti) impulzusátviteli hatékonyságára. Az (51) összefüggést felhasználva az ékre ható erő meghatározható, figyelembe véve, hogy a nyaláb sugara $w_{0}=100 \mu m$ és a megvilágító fényforrás teljesítménye $P=3 \mathrm{~W}$ (amiből $\mathrm{kb} .50 \%$ a veszteség $L$ )

$$
\begin{gathered}
I=L \frac{2 P}{w_{0}^{2} \pi} \\
F=\frac{I}{c}\left(T_{1} \cdot \sin (2 \alpha)-T_{2} \cdot \sin (2 \beta)\right)=4.7 p N
\end{gathered}
$$

Az ékre ható erőből a sebességük is megbecsülhető a Stokes-féle ellenállás törvény segítségével:

$$
v=\frac{F}{6 \pi \eta r}
$$

A becslés során egy olyan egyszerüsítéssel éltem, ahol az ékek valódi alakja helyett egy gömbalakot feltételeztem, így az ennek megfelelő effektív terület sugara kifejezhető az alábbi egyenlettel:

$$
r=\sqrt{\frac{T_{3}}{\pi}}
$$

ahol $T_{3}$ az ék mozgás irányába eső felülete.

A becsült maximális sebesség $46.6 \mu \mathrm{m} / \mathrm{s}$-nak adódott, amit összevetve a kísérletekben kapott értékekkel megállapítható, hogy becsült és mért értékek jó egyezést mutatnak. Meg kell jegyezni azonban, hogy a becslés során számos tényezőt elhanyagoltam, például nem vettem figyelembe a folyadék/levegő határfelületen fellépő erőket. Ezen felül a Stokes törvény olyan peremfeltételek 
mellett igaz, ahol a folyadék minden irányban végtelen kiterjedésű, míg az ékek a teret félig betöltő folyadékban úsznak. Továbbá azt sem vettem figyelembe, hogy az ékek felülnézetben nem téglalap, hanem ellipszis alakúak.

Az ékek mozgását üveg-víz határfelületen elhelyezkedő ékekkel is demonstráltam, aminek eredményeit a 31. ábra mutatja. Sok szempontból hasonló viselkedést mutatnak az ékek üvegen mozogva, mint a függő cseppes kísérletekben. Mozgásuk pályája jellemzően egyenes, vagy enyhén görbült, és képesek teljesen áthaladni a megvilágított területen. A 31. ábra beszúrt ábráján az is megfigyelhető, hogy a pályák többsége ugyanabba az irányba mutat. Ez a viselkedés annak a következménye, hogy a megvilágított ékek hasonló orientációban kezdték meg a mozgásukat, amit a mérés végéig megtartottak. Mivel az üveg/víz határfelületen elvégzett kísérleteim elsődleges célja a demonstráció volt, részletesebben nem vizsgáltam a mozgásukat.

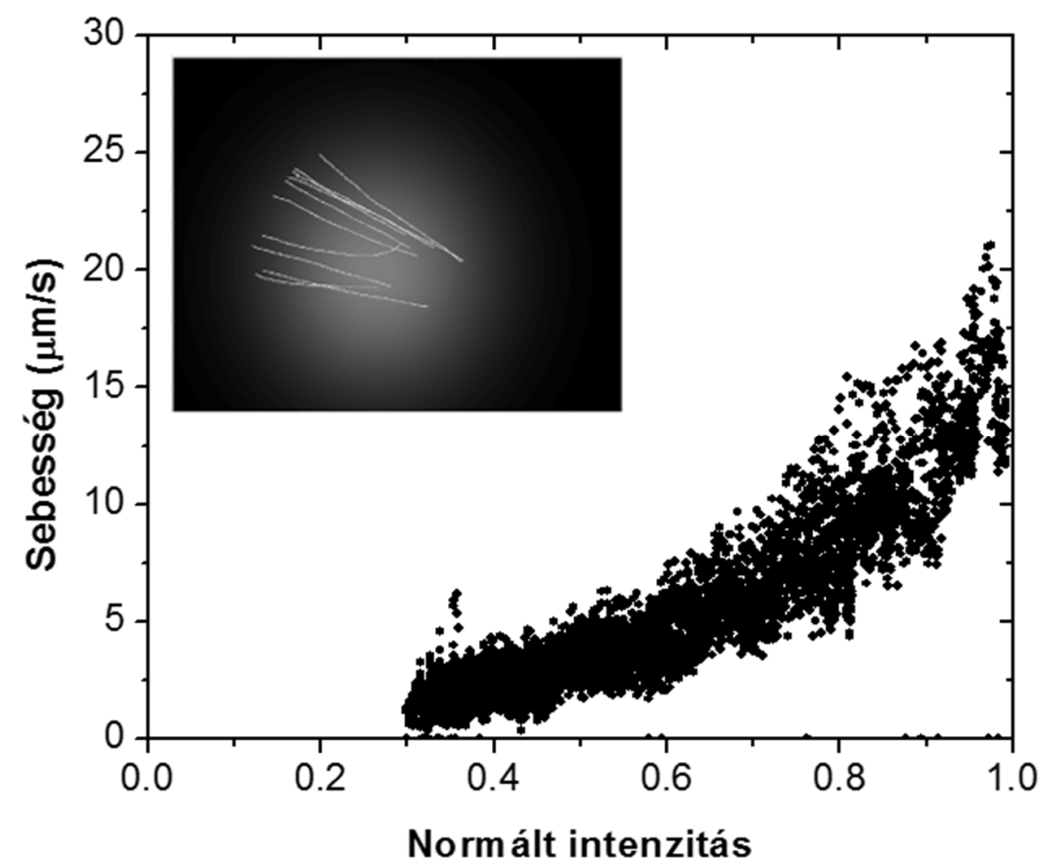

31. ábra Az ékek sebessége a normált intenzitás függvényében $3 \mathrm{~W}$ teljesítményü $110 \mu \mathrm{m}$ sugarú megvilágító fényforrás (veszteség nélkül $\mathrm{I}_{\max }=1.39 \cdot 10^{4} \mathrm{~W} / \mathrm{cm}^{2}$ ) esetén az üveg/víz határfelületen. A beszúrt képen a mozgások pályái láthatók a megvilágításhoz képest.

A hasonlóságok mellett némi eltérés is megfigyelhető a függő cseppes kísérletekhez képest. Egyrészt megállapítható, hogy stabilabban tartják a pályájukat, sokkal iránytartóbb az ékek mozgása üvegen, illetve a pályák elején és végén a fluktuációk is lényegesen kisebbek. 
Az üvegen elért sebesség nagyságrendileg hasonló, mint amit a függőcseppes kísérletekben tapasztaltunk, kb. $10 \mu \mathrm{m} / \mathrm{s}$, azonban a maximálisan elérhető sebesség lényegesen kisebb, nem haladja meg a $20 \mu \mathrm{m} / \mathrm{s}$-ot. A sebességek fluktuációja is lényegesen kisebb, a mozgás egyenletesebb, adott intenzitáson egy jól meghatározott tartományban változik a sebesség. Az üvegen elvégzett kísérletekben az ékek mozgásához tartozik egy minimális intenzitás, ami alatt nem jönnek mozgásba, és ez a határintenzitás érték kb. másfélszerese annak az értéknek, amit levegö/víz határfelületen mértem (figyelembe vettem azt is, hogy az $I_{\max }$ nem egyenlő a különböző kísérletekben). Ez összhangban van azzal a (nem meglepő) ténnyel, hogy üvegen a súrlódás nagyobb, mint a levegö/víz határfelületen. 


\subsubsection{Perzisztenciahossz}

Az ékek mozgásának rendkívül fontos jellemzője a mozgás rendezettsége. Alapvetően az ékek stabil mozgást végeznének az alakjuk által meghatározott irányban, azonban bizonyos tényezők hatására megváltoztatják az irányukat. Például a rotációs diffúzió, ami a közeg által az ékre ható erők forgatónyomatékának a következménye, de a struktúra, illetve a megvilágítás „tökéletlensége” szintén hozzájárulhat a megfigyelt irányváltozáshoz. A mozgás rendezettségének számszerü jellemzésére a perzisztenciahossz mennyiséget használtam.

Eredetileg a perzisztenciahossz fogalma hosszú molekulák, például polimerek mechanikai tulajdonságainak jellemzésére használt mennyiség. Jelentése az a hosszúság, ameddig egy polimerlánc "rugalmas rúdként viselkedik", illetve az ennél hosszabb polimerlánc különbözö részei véletlenszerüen orientálódnak. Hasonló elgondolással a perzisztenciahossz fogalmát fel lehet használni az ékek mozgásának jellemzésére is olyan módon, hogy a polimerlánc szerkezetét a mozgás pályájával helyettesítjük. Ekkor a perzisztenciahossznál rövidebb szakaszon belül az ékek pályája iránytartó, korreláció van az egyes pályaszakaszok között, azon túl pedig úgy mozognak, mintha mozgásuk véletlenszerü lenne. A perzisztenciahosszat két módszerrel is meghatároztam, amelyek a „,Worm-like chain” modell (WLC modell) és a „Persistent random walk" modell (PRW modell) voltak.

\subsubsection{WLC modell}

Tekintsünk egy pályát, például ami a 32. ábrán is látható. Azt vizsgáljuk, hogy egy $\mathrm{O}$ viszonyítási ponttól L pontig a mozgás pályáján $l$ utat megtéve mekkora lesz a haladási (érintő) irányeltérése az $\mathrm{O}$ viszonyítási pontban vett irányhoz képest. A WLC modell szerint a két érintő által bezárt $\theta$ szög koszinuszának várható értéke a megtett út függvényében exponenciálisan csökken:

$$
\langle\cos (\theta)\rangle=\exp \left(-\frac{l}{P}\right)
$$

ahol a $<>$ zárójel a $\cos (\theta)$ várható értékét jelenti, $l$ az $\widehat{O L}$ a pályaszakasz hossza, míg $P$ a perzisztenciahossz [140]. 


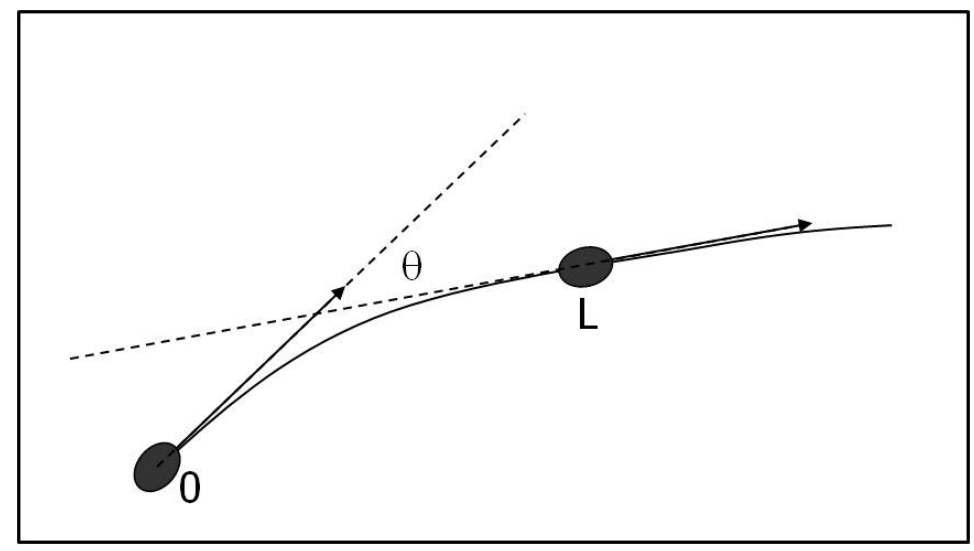

32. ábra A perzisztenciahossz meghatározására szolgáló paraméterek származtatása.

A számolást a pálya minden pontjára el kell végezni. A teljes pályán minden 1 hosszúságú pályaszakaszra a kezdő és végpontba húzott érintők által bezárt szög koszinuszát kiszámolva és azok átlagolásával kapjuk $<\cos (\theta)>$ várható értékét. A várható értékeket a pályaszakasz hosszának függvényében ábrázolva exponenciális illesztéssel a perzisztenciahossz meghatározható.

A 33. ábrán látható hogyan változik a $<\cos (\theta)>$ függvény a pályaszakaszok hosszának függvényében. Azonnal szembeötlő, hogy a várható érték nem egy exponenciális függvény szerint cseng le, hanem két lényeges eltérést lehet megállapítani. Egyrészt a görbe elején egy „plató” szakasz figyelhető meg és a görbék nem 1-ből indulnak, hanem alacsonyabb értékről. Másrészt a görbe vége az „ellaposodó” exponenciális lecsengés helyett élesen levág.

A plató megjelenése azzal indokolható, hogy a haladási iránynak már kis pályaszakaszok esetén is van valamekkora fluktuációja. Ez a fluktuáció lehet valós, de megjelenhet a kiértékelés során fellépő numerikus hibák következtében is. A plató addig lesz domináns, amíg a pálya valódi eltérülése nem lesz nagyobb a fluktuációk által meghatározott szögtartománynál.

Az éles lecsengés azzal magyarázható, hogy a perzisztencia hossz nem konstans a pálya teljes hosszán. Ennek oka, hogy az ékek nem homogén fényforrással lettek megvilágítva, ami miatt a megvilágítás legintenzívebb (középső) tartományain nagyobb sebességgel, a külső részein egyre lassabb sebességgel mozognak. Ennek következménye, hogy a fluktuációk egyre inkább dominálnak a szélső tartományon, ami rosszabb iránytartást, azaz rendezetlenebb mozgást és rövidebb perzisztencia hosszat jelentenek. 


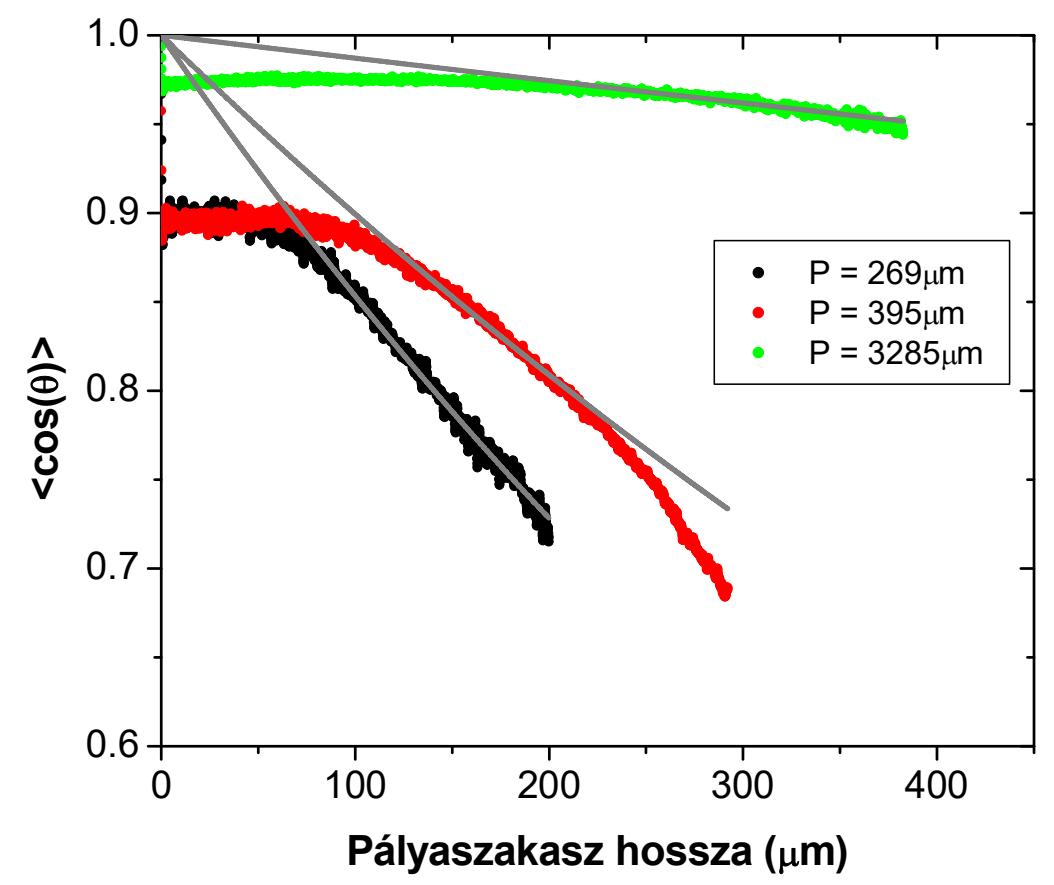

33. ábra $\mathrm{A}<\cos (\theta)>$ függvény változása a pályaszakaszok hosszának függvényében.

A fentiek okok miatt egy exponenciális görbe illesztése nem tủnik korrektnek az egész görbére vonatkozóan. Abban az esetben, ha az illesztést nem a teljes görbére, hanem csak annak rövidebb szakaszára végezzük el, akkor hasznos eszköz lehet a perzisztecia hossz becslésére. Ha a plató rész a görbéken nem lenne, akkor minden görbe 1-ről indulna és monoton csökkenő exponenciális függvény lenne egészen addig, amíg a perzisztenciahossz konstansnak tekinthető. Ha az exponenciális illesztést úgy végezzük el, hogy görbe kezdeti részén a plató szakaszt, illetve a görbe végén azt a részt, ahol elkezd eltérni az exponenciális függvénytől elhagyjuk, akkor egy becslést lehet adni a perzisztencia hossz értékére. A 33. ábra néhány esetet mutat be, amikor az illesztés elvégezhető volt. Azonban volt olyan eset is, amikor már a fenti módszerrel sem lehetett az illesztést elvégezni.

Az illesztést ilyen módon elvégezve az összes görbére azt kaptam, hogy a perzisztencia hossz 150 és $3000 \mu \mathrm{m}$ között változik. Az értékek nagy szórása annak lehet a következménye, hogy a perzisztenciahossz sebességfüggő, ennek megfelelően arra is érzékeny, hogy az adott ék mozgása hol halad át a megvilágító fényforráson. Például abban az esetben, ha az ék mozgása során a fényforrás külső tartományain halad át, akkor jellemzően alacsonyabb sebessége lesz, aminek 
következtében a perzisztencia hossza is alacsonyabb lesz, szemben a nyaláb központi részén áthaladó ékkel.

\subsubsection{PRW modell}

A perzisztencia hosszat a $P R W$ modell segítségével is meghatároztam. A modell feltevése szerint egy részecske mozog adott irányba $v$ sebességgel, illetve adott időközönként $p$ valószínűséggel tartja ugyanazt az irányt, vagy 1- $p$ valószínüséggel irányt változtat ( $p=1 / 2$-nél a mozgás teljesen véletlenszerü, $p=1$-nél a részecske csak egy irányba mozoghat). Amennyiben $p \sim 1$, a Fürth formula alábbi alakja írja le a részecske kezdő ponttól való távolság négyzetének várható értékét 1 dimenzióban [141]:

$$
\left\langle d(t)^{2}\right\rangle=2 \frac{v^{2}}{\beta^{2}}[\beta t-1+\exp (-\beta t)]
$$

ahol $v$ a részecske sebessége, $\beta=1 / T_{p}, T_{p}$ a perzisztencia idő és $d(t)=x(t)-x\left(t_{0}\right)$ a kezdő és végpozíció közötti távolság. A Fürth formula 2 dimenzióban használt alakja [142]:

$$
\left\langle d(t)^{2}\right\rangle=2 n D\left[t-T_{p}\left(1-\exp \left(-\frac{t}{T_{p}}\right)\right)\right]=4 D T_{p}\left[\frac{t}{T_{p}}-1+\exp \left(-\frac{t}{T_{p}}\right)\right]
$$

ahol bevezetésre került a diffúziós állandó $(D)$ és $\mathrm{n}=2$ a dimenzió. A (62) és (63) egyenletek öszevetéséből a diffúziós állandó is kifejezhető:

$$
D \sim v^{2} T_{p}
$$

Megjegyezném, hogy a fenti diffúziós állandó nem feltétlenül egyezik meg az Einstein-Stokes formulával kapott diffúziós állandóval, de ezt a későbbiekben még tárgyalom.

A (63) formulának két speciális esete - amikor a vizsgált időtartam sokkal rövidebb a perzisztencia időnél, illetve amikor sokkal hosszabb - az alábbi egyenletekre egyszerüsödik:

$$
\begin{gathered}
\left\langle d(t)^{2}\right\rangle=\frac{2 D}{T_{p}} t^{2}, t<<T_{p} \\
\left\langle d(t)^{2}\right\rangle=4 D t, t>>T_{p}
\end{gathered}
$$


A kísérletileg meghatározott $d(t)$ görbéket társítva a fenti véletlenszerü mozgást leíró formulákkal, az alábbi megállapítások tehetők:

i) rövid időskálán az ékek mozgása közelítőleg olyan, mintha konstans $v=\sqrt{2 D / T_{p}}$ sebességgel haladnának;

ii) hosszú időskálán az ékek mozgása olyan, mint a diffúzió.

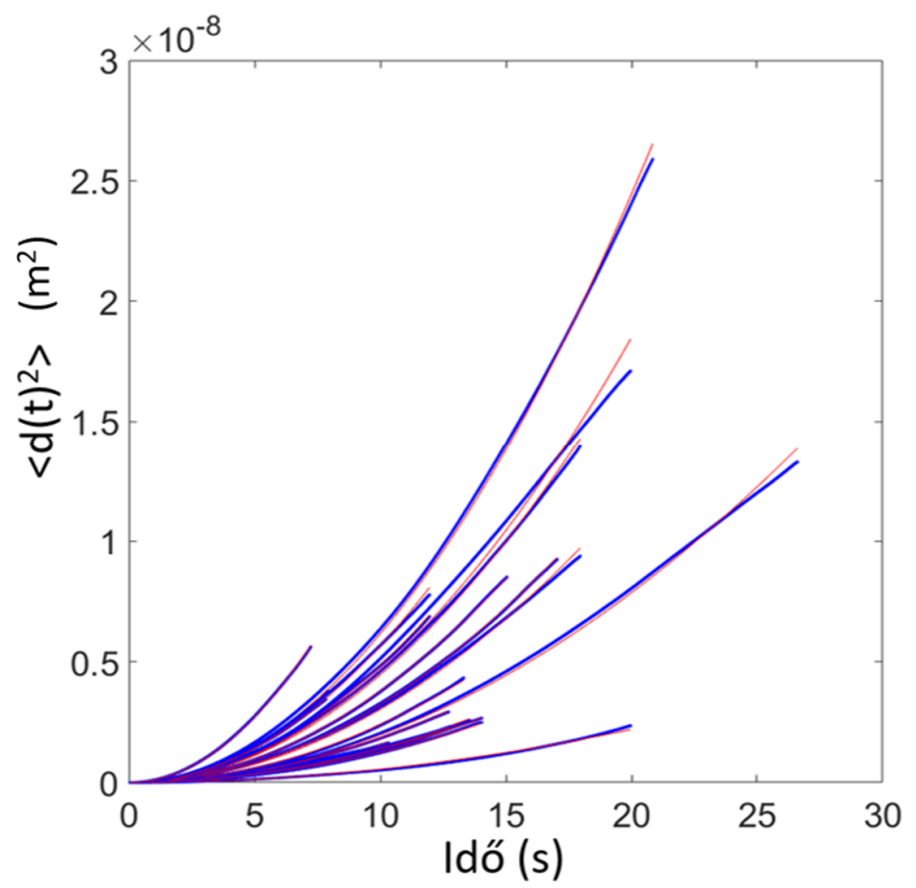

34. ábra Az ékek elmozdulás négyzetének várható értéke az idö függvényében (kék görbe),

illetve az illesztett Fürth formula (piros görbe). Minden görbe egy pályának felel meg.

A kísérletekben kapott pályákra kiszámolva az elmozdulás négyzet várható értékének időfüggését $<d(t)^{2}>$, amit a 34. ábra mutat, és a (64) egyenletben leírt Fürth formulát ráillesztve az illesztési paraméterekből a perzisztenciaidő és a diffúziós állandó meghatározható. A diffúziós állandó $1 \cdot 10^{-}$ ${ }^{9}-1 \cdot 10^{-8} \mathrm{~m}^{2} / \mathrm{s}$, míg a perzisztencia idő $100-400 \mathrm{~s}$ között változott. A részecskék $v=\sqrt{2 D / T_{p}}$ sebességét felhasználva a perzisztenciaidő segítségével a perzisztenciahossz meghatározható:

$$
l_{p}=v T_{p}=\sqrt{2 D T_{p}}
$$

ami a különböző pályákra jellemzően 700 és $3000 \mu \mathrm{m}$ között változott. Látható, hogy a modell a teljes pályára jól illeszthető, azonban itt is megfigyelhető, hogy az illesztett görbe nem mindig 
követi teljesen a kísérletileg származtatott görbét. Az eltérés oka hasonló lehet, mint ami már a WLC modellnél is említésre került, a perzisztencia hossz eltérő lehet a pálya különböző szakaszain. Ezt erösíti az a tény is, hogy egy adott pálya esetén annak egy rövidebb szakaszára jobb illeszkedést lehet elérni, mint a teljes pályára.

\subsubsection{A diffúziós állandó}

A $P R W$ modellben a diffúziós együttható egy illesztési paraméter. Az Einstein-Stokes formula alapján számolva a diffúziós együtthatót:

$$
D=\frac{k_{b} T}{6 \pi \eta r} \approx 4.39 \cdot 10^{-14} \frac{m^{2}}{s}
$$

ahol $k_{b}$ a Boltzmann állandó, $T$ a hömérséklet, $\eta$ a közeg viszkozitása, és $r$ a részecske sugara (gömbalakú részecskét feltételezve). Az illesztett és fenti formulával számolt értékeket összehasonlítva megállapítható, hogy 5 nagyságrend eltérés van közöttük. Figyelembe véve, hogy az Einstein formula csak a hőmozgás hatására bekövetkező diffúziót veszi figyelembe, arra a következtetésre jutunk, hogy az ékek fluktuáló mozgását dominánsan nem a hőmozgás határozza meg. A megvilágítástól olyan hatások is fellépnek (például: inhomogén megvilágítás, a csúszási felület szabálytalansága, stb.), amelyek a részecske véletlenszerü mozgását dominánsan meghatározzák. Az illesztésből származtatott diffúziós együttható gyakorlatilag a teljes (optika ék - közeg) rendszer működését tükrözi.

\subsubsection{A WLC és a PRW modell összehasonlítása}

A kétféle modell eltérő módon vezeti be a perzisztenciahossz fogalmát. Nagyságrendileg a két modell hasonló perzisztencia hosszakat szolgáltat ( 100-1000 $\mu \mathrm{m})$ és az értékek is jól korrelálnak egymással, azonban általában a PRW modell 2-3-szor nagyobb értékeket ad, ahogy az a 35. ábrán is megfigyelhető. Mivel a WLC modellben csak egy rövid tartományra végezhető el az illesztés, jóval nagyobb lesz a bizonytalanság és emiatt lehet jelentős eltérés a két modell között. 


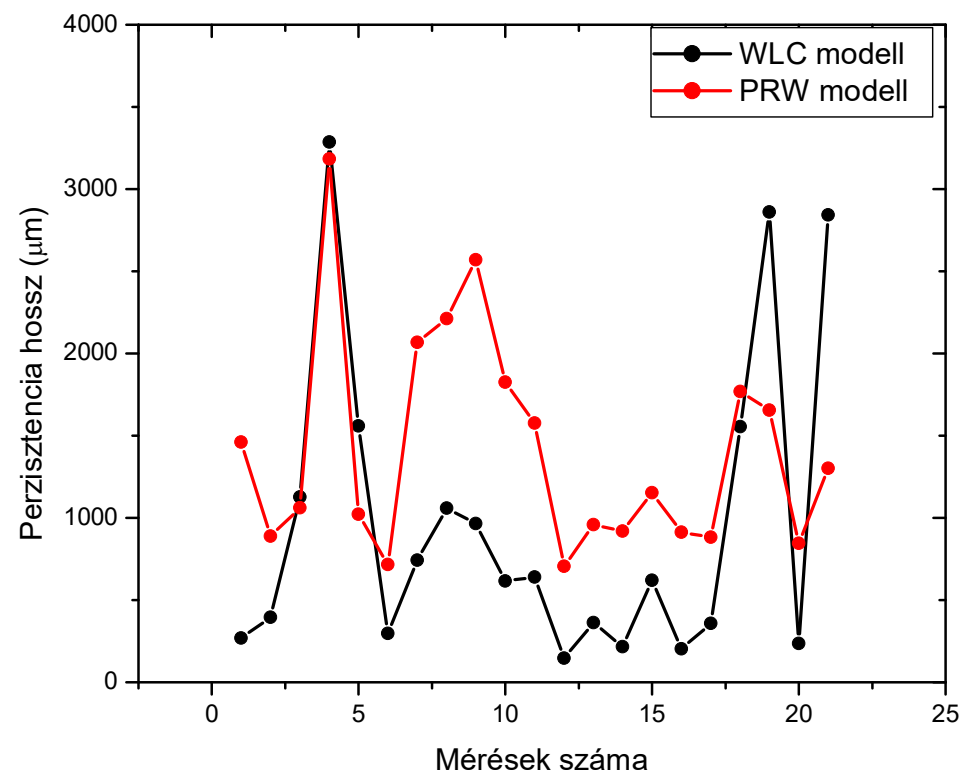

35. ábra A $W L C$ modell és a $P R W$ modell által kapott perzisztencia hosszak összehasonlítása. 


\subsubsection{Tézispont}

Kialakítottam egy fénnyel hajtott mikrorobot/mikroúszó rendszert. A rendszerben az egyes részecskék önállóan mozognak, abban az értelemben, hogy mozgásukhoz az energiát a fényből nyerik, de mozgásuk irányára a fény nincs hatással. A részecskék fotopolimerizációval előállított ékek, amelyeket aranyréteggel vontam be. E részecskék mozgását tanulmányoztam megvilágítás hatására.

Demonstráltam, hogy e testek képesek megvilágítás hatására mozogni mind víz/üveg, mind víz/levegő határfelületen. A mozgásuk sebessége - ami tipikusan $10 \mu \mathrm{m} / \mathrm{s}$ - arányos a megvilágító fényforrás lokális intenzitásával, míg irányát a testek helyzete határozza meg. A mozgások pályájából kétféle módszerrel is meghatároztam az ékek mozgására jellemző perzisztencia hosszat, ez 100 - $1000 \mu \mathrm{m}$ nagyságrendü volt. A perzisztenciahossz az ékek méreténél 1-2 nagyságrenddel nagyobb volt. [T1] 


\subsection{Kísérletek gurigákkal}

A gurigákat tartalmazó mintákkal kétféle kísérletet végeztem el, ahol az egyik esetben prizmaszerü gurigákat, míg a második esetben valódi 3D gurigákat használtam. A kísérleteimben a gurigákat transzmisszióban figyeltem meg. Mivel a gurigák felülete arannyal volt bevonva (a magas reflexió érdekében), a fény nem haladt át rajtuk, és emiatt az egyes gurigáknak csak az árnyékát lehetett látni.

A prizmaszerü gurigák esetében soha nem tapasztaltam mozgást, ellenben a 3D gurigák megvilágítás hatására mozogni kezdtek. A gurigák mozgásának egyik fontos jellemzője, hogy mennyire haladnak az alakjuk által meghatározott irányba. Ennek jellemzésére meghatároztam a pillanatnyi sebesség vektor és a guriga forgástengelyére merőleges irány (tiszta gördülés iránya) által bezárt szöget. A szögeloszlást a 36. ábrán látható hisztogram mutatja. Megfigyelhető, hogy a mozgások iránya egy nagyon szűk szögtartományban van, amelyek csupán kis, jellemzően 10 fok, vagy annál kisebb mértékü eltérést mutatnak a tiszta gördülés irányától.

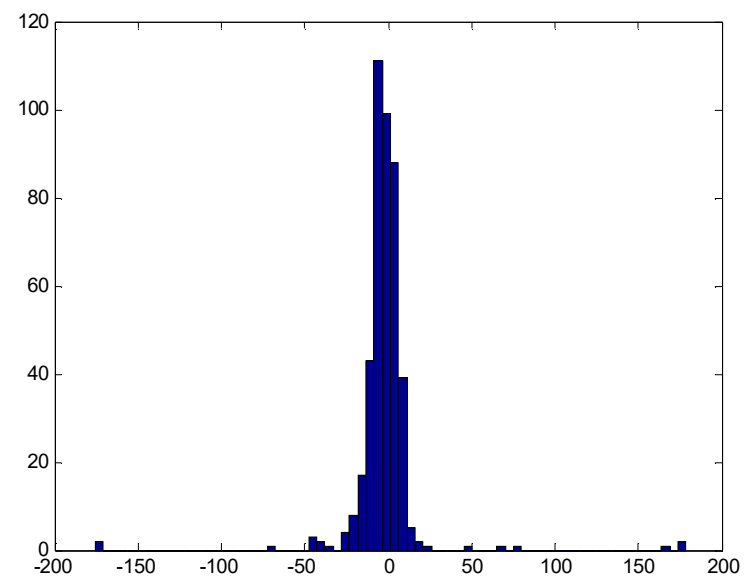

36. ábra A gurigák sebesség vektora és a tiszta gördülés iránya által bezárt szög eloszlása a mozgás során.

Annak eldöntésére, hogy a helyváltoztatás gördüléssel vagy csúszással történik, a polimerizáció során, az egyik oldalon visszamaradt távtartók nyújtottak segítséget. Ezekből az egyik oldalon $5 \mathrm{db}$ volt (amiből 4db a kerület mentén szimmetrikusan helyezkedett el, és egy volt középen), ahogy a 37. ábrán látható gurigákon bal oldalon helyezkednek el. Bár a gurigáknak csak az árnyékát láttam, 
ezen távtartók mozgásából következtetni lehetett a gördülés fázisára, aminek segítségével el lehet dönteni, hogy milyen mértékben haladnak gördüléssel és csúszással.
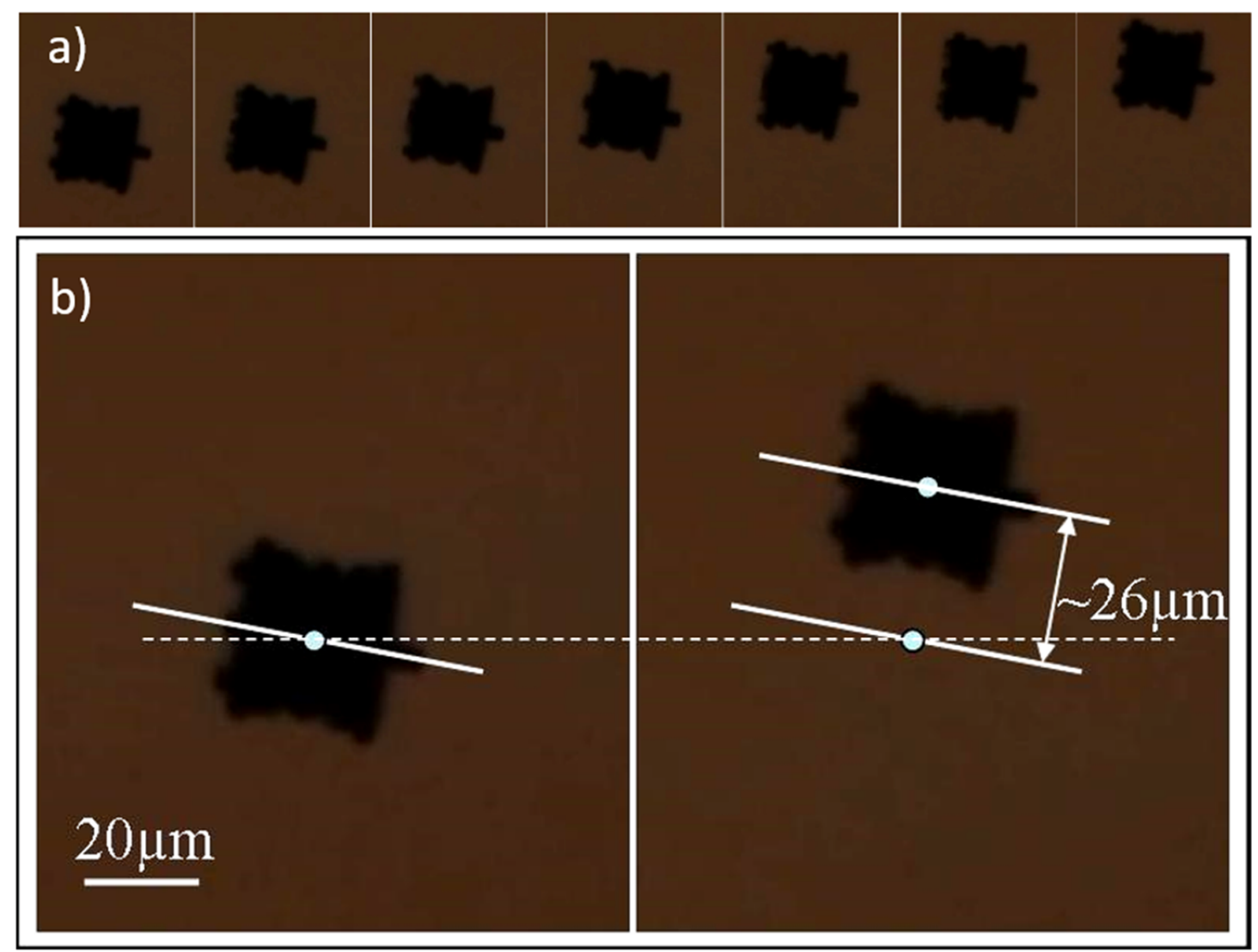

37. ábra a) A guriga mozgása során kialakuló árnyék mintázatok egy negyed körülfordulás során. b) A kezdő és végállapotok közötti távolság.

Az árnyék mintázata a mozgás során folyamatosan változott. Amennyiben a guriga gördüléssel halad, ezen mintázat adott távolságonként megismétlődik. Egy r sugarú guriga esetén, figyelembe véve a távtartók szimmetrikus elhelyezkedését, tiszta gördülés esetén a mintázat $l_{g}=2 r \pi / 4=r \pi / 2$ távolságonként ismétlődik. A kísérleteimben a gurigák sugara kb. $r=15 \mu m$ volt, amihez $l_{g}=23.7 \mu \mathrm{m}$ mintázat ismétlődési távolság tartozott. A kísérleteimben megfigyelt ismétlődési távolság kb. $26 \mu m$ volt, ami kb. 10\%-kal nagyobb, mint a tiszta gördüléshez tartozó $l_{g}$ érték.

Összegezve a gurigák az alakjuk által meghatározott irányba dominánsan gördüléssel és csupán kismértékü csúszással haladnak. A forgástengely irányában történő elmozdulásuk nem jelentős. 


\subsubsection{Az inhomogén megvilágítás esetleges hatása a guriga mozgására}

A gurigák megvilágítására homogén intenzitáseloszlás lett volna ideális, azonban a valós kísérleti körülmények között egy kitágított Gauss nyalábot alkalmaztam, mind az alsó, mind a felső megvilágításra. A gurigák mozgásának vizsgálata során fontos figyelembe venni az inhomogén megvilágítás hatását, mivel a forgástengely különböző oldalain eltérő intenzitás is képes meghajtani a mozgást függetlenül a guriga struktúrájától. (Az ékek esetén a megvilágító fényforrás inhomogenitása a mozgást nem befolyásolta jelentősen, mivel azok csak felülről és dominánsan csak az egyik oldalon lettek kivilágítva, és az így beérkező sugarak hatása összegződött.) Az alábbiakban részletesen megvizsgálom e hatás esetleges szerepét.

A 38. ábrán látható egy guriga elvi rajza (aminek tetszőleges az alakja, de a forgástengelye körül $90^{\circ}$-os forgásszimmetriával rendelkezik), amint alsó és felső irányból is inhomogén módon van kivilágítva. Ha feltesszük, hogy lassan változik az intenzitás, és csak az elsőrendű tagokat hagyjuk meg, a magasabbrendủ deriváltakat elhanyagoljuk, illetve a vizsgálódás során csak a forgástengelyre merőleges komponensre szorítkozunk (a forgástengellyel párhuzamos komponens nem hoz létre rotációt, csak a tengely irányába tolhatja el a gurigát), akkor az intenzitás felbontható egy homogén és egy inhomogén tagra az alábbi alakban:

$$
\begin{aligned}
& I_{i}^{+}=I_{i}+\Delta I_{i} \\
& I_{i}^{-}=I_{i}-\Delta I_{i}
\end{aligned}
$$

Ahol $I_{i}$ az átlag intenzitás, $\mathrm{i}=1$, vagy 2 jelzi az felső, illetve az alsó megvilágítást. $\Delta I$ a gradiens miatt az átlag intenzitástól való eltérés. A + a forgástengelytől jobbra, a - a forgástengelytől balra eső tartomány intenzitását jelzi. Fontos megjegyezni, hogy a folyadékba merülö guriga esetén az intenzitások azért bonhatók fel homogén és inhomogén tagra (és hatásaik azért vizsgálhatók különkülön), mert a Stokes egyenletek lineárisak, így a hatások függetlenül összeadhatók. 


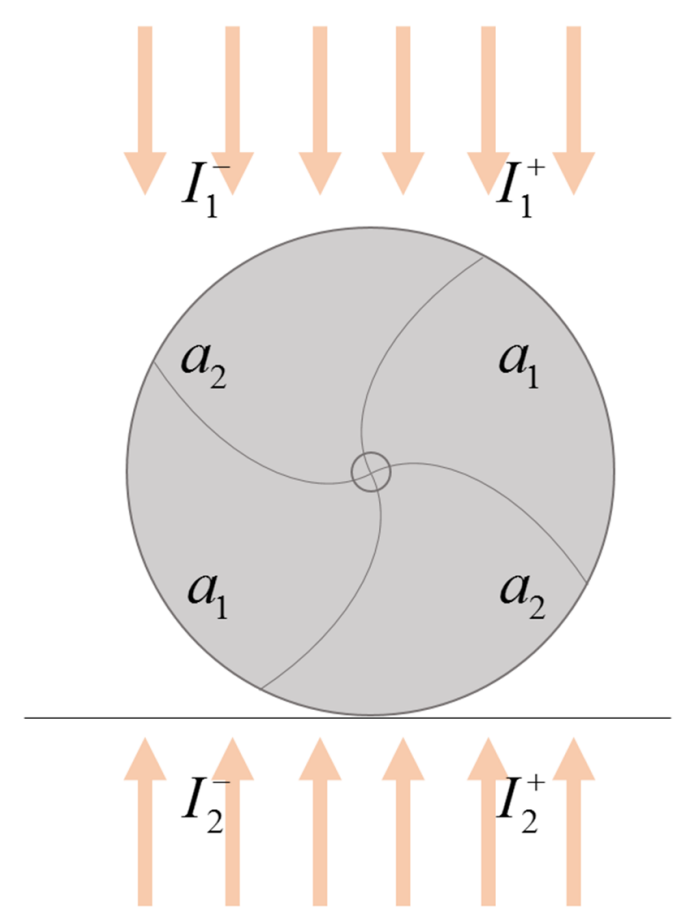

38. ábra guriga mozgása inhomogén megvilágítás hatására.

Ekkor a gurigára ható forgatónyomaték:

$$
\begin{gathered}
M=I_{1}^{+} a_{1}+I_{2}^{-} a_{1}-I_{1}^{-} a_{2}-I_{2}^{+} a_{2}=\left(I_{1}+\Delta I_{1}+I_{2}-\Delta I_{2}\right) a_{1}-\left(I_{1}-\Delta I_{1}+I_{2}+\Delta I_{2}\right) a_{2} \\
M=\left(I_{1}+I_{2}\right)\left(a_{1}-a_{2}\right)+\left(\Delta I_{1}-\Delta I_{2}\right)\left(a_{1}+a_{2}\right)
\end{gathered}
$$

$a_{1}$ és $a_{2}$ a guriga alakjából származó konverziós faktor, ami megadja, hogy egységnyi intenzitás mekkora nyomatékot hoz létre az adott orientációban az adott oldalon. A (72) egyenletböl kiolvasható, hogy az alsó és felső megvilágítás ugyanolyan irányú forgást hajt meg (az átlagos intenzitás összeadódik), míg az alsó és felső megvilágításban az azonos irányú gradiensek ellentétes irányú forgást indukálnak. 

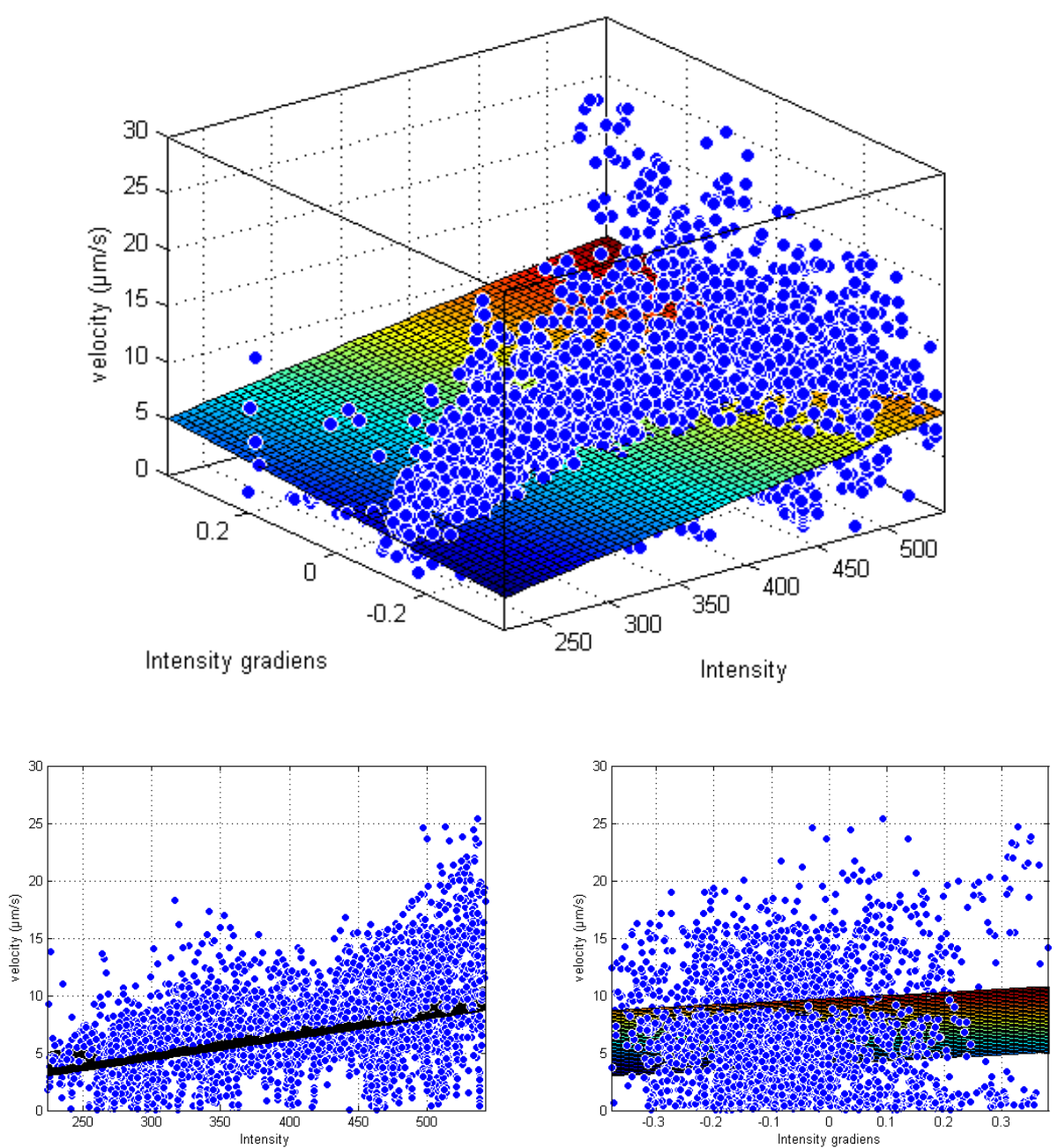

39. ábra Az ábrán látható síkot egy $z=a x+b y$ függvény adatokra történő illesztésével kaptuk, ahol $\mathrm{a}=0.0180(\mu \mathrm{m} / \mathrm{s}) /\left(\mathrm{W} / \mathrm{cm}^{2}\right)$ (intenzitáshoz tartozó együttható), $\mathrm{b}=2.72(\mu \mathrm{m} / \mathrm{s}) /\left(\mathrm{W} / \mathrm{cm}^{3}\right)$ (intenzitás gradienshez tartozó együttható).

A fentiek alapján, hogy pontos képet kapjunk, milyen mértékben befolyásolja az intenzitás gradiens a gurigák mozgását, a gurigák sebességét 3 dimenzióban ábrázoltam, az alsó és felső megvilágítás összintenzitásának, és az intenzitásgradiensek különbségének függvényében, ami a 39. ábrán látható. Ez alapján megállapítható, hogy a gurigák tipikus sebessége $10 \mu \mathrm{m} / \mathrm{s}$ nagyságrendü, és a maximális sebesség nem haladja meg a $25 \mu \mathrm{m} / \mathrm{s}-$ ot. A sebességnek rendkívül nagy a szórása, jellemzően 0 és az adott intenzitáshoz tartozó maximális sebesség között minden 
érték megjelenik. Ez annak a következménye, hogy mozgása sok esetben nehézkes, és időnként a guriga elakad.

Megfigyelhető, hogy a sebesség az intenzitás függvényében lineáris, míg a gradiens függvényében alig észrevehetően változik. Ez alapján a sebességet dominánsan meghatározó tag a megvilágítás átlagos intenzitása, míg a gradiensnek jelentôsen kisebb hatása van. Ezt a tényt támasztaja alá, hogy azokon a helyeken, ahol a gradiens értéke 0, a gurigák ott is nagy sebességü mozgásra képesek.

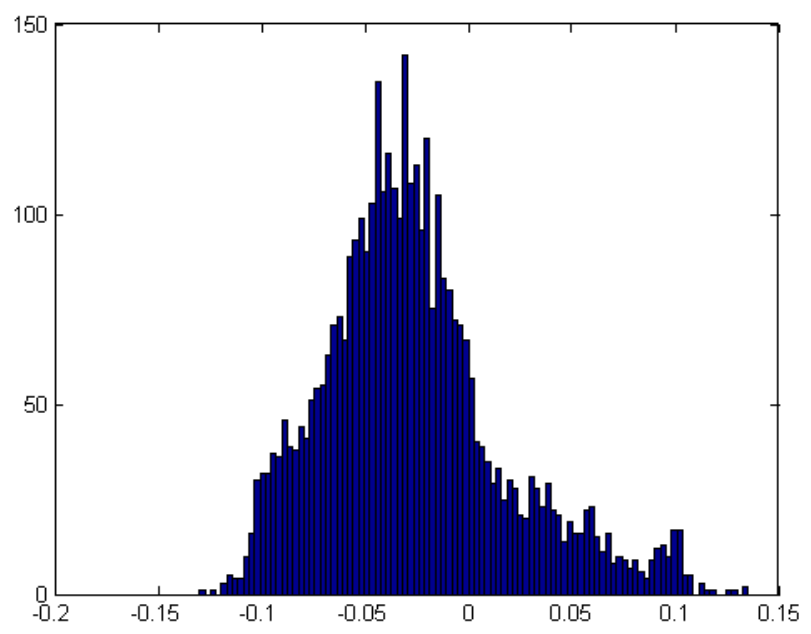

40. ábra A különböző mérési pontokhoz tartozó by/ax hányadosokból készített hisztogram.

Mivel az alacsony Reynolds számok tartományában a fellépő erők, forgatónyomatékok, illetve sebességek és szögsebességek között lineáris az összefüggés, a sebesség a (72) egyenletben leírt nyomatékkal lesz arányos. Így az adatokra a (72) egyenlettel formailag megegyező $v \sim M=a x+b y$ alakú függvényt illesztettem, ahol $\boldsymbol{x}=\left(I_{1}+I_{2}\right)$, míg $y=\left(\nabla I_{1}-\nabla I_{2}\right) \cdot \hat{\boldsymbol{n}}$ (a $\nabla I$ az intenzitás gradiensét jelöli). Az illesztést a 39. ábra mutatja. Abból a célból, hogy megvizsgáljam, az intenzitásgradiensnek átlagosan mekkora a sebességjáruléka, hisztogramon ábrázoltam a különböző mérési pontokhoz tartozó és az illesztésből származó by/ax hányadosokat, amit a 40. ábra mutat. Az eloszlás várható értéke - 0.03 körül van, és jellemzően nem haladja meg a 0.1-et, azaz átlagosan 3\%-os járulékot adnak a sebességhez, de nem haladja meg a 10\%-ot. Az előzőek alapján megállapítható, hogy az intenzitásgradiensnek nincs jelentős hatása a kísérletekre. 
Bár a kísérleteimben inhomogén (TEM00 Gauss) megvilágítást alkalmaztam, gyakorlatilag igaz az a közelítés, hogy a nyaláb lokálisan homogénnek tekinthetö.

\subsubsection{Perzisztencia hossz}

A gurigák mozgásának rendezettségét jellemző perzisztenciahosszat csak a $P R W$ model segítségével határoztam meg. Az illesztés eredményét a 41. ábrán mutatom. Az illesztésből a perzisztencia idöre $10-90 \mathrm{~s}$ közötti értékek, míg a diffúziós állandóra $10^{-9}-5 \cdot 10^{-9} \mathrm{~m}^{2} / \mathrm{s} \mathrm{közötti}$ értékek adódtak.

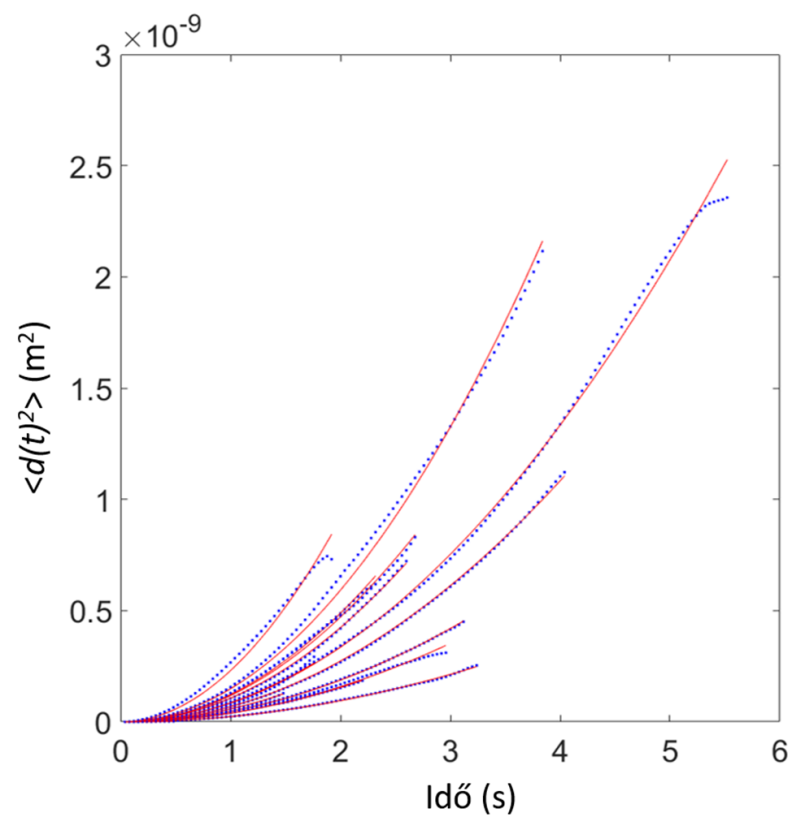

41. ábra A gurigák elmozdulás négyzetének átlaga az idő függvényében (kék görbe), illetve az illesztett Fürth formula (piros görbe). Minden görbe egy pályának felel meg.

Az illesztési paraméterekből számolt perzisztencia hossz $100-800 \mu \mathrm{m}$ között változik. Megfigyelhetö, hogy a kísérletekből származó görbékre jól illeszthető a Fürth modell, azonban jellemzően a görbék végső szakaszán némi eltérés is tapasztalható. Ennek oka, hasonlóan az ékekhez, hogy a perziszenciahossz nem egy konstans érték a mozgás teljes pályáján. 


\subsubsection{A gurigák és ékek összehasonlitása}

Összehasonlítva a gurigákat és az ékeket, azt lehet mondani, hogy mindkét esetben sikerült autonóm mozgásra képes mikrorobotokat előállítani. A megvilágítás hatására az ékek transzlációs, míg a gurigák rotációs/gördülő mozgást végeznek. Mozgási energiájukat mindkét esetben a fényből nyerik. A mozgásuk irányát az aktuális orientációjuk határozza meg.

Jelentős különbség adódott az elért sebességben. Míg az ékek sebessége tipikusa néhány $10 \mu \mathrm{m} / \mathrm{s}$, de akár a $100 \mu \mathrm{m} / \mathrm{s}$ sebességet is elérhették, hasonló intenzitást alkalmazva a gurigák tipikusan $5-10 \mu \mathrm{m} / \mathrm{s}$, de legfeljebb $20-25 \mu \mathrm{m} / \mathrm{s}$ sebességgel mozogtak. A különbség egyrészt adódhat a méretbeli különbségekből, ugyanis a gurigák térfogata 27-szer nagyobb volt az ékek térfogatánál, ami arányosan nagyobb ellenállást is jelenthet a közeg részéről. Bár a guriga esetén a nagyobb mérettel nagyobb a begyüjtött fényenergia is, mivel 10-szer nagyobb területen hatnak kölcsön a meghajtó fényforrással. Másik ok lehet, hogy az ékek esetén majdnem a teljes felületük a mozgás meghajtását segíti, míg a gurigák esetén csupán a teljes felületük felén keletkező impulzustöbblet szolgálja a mozgásukat, ami végeredményben sokkal rosszabb hatásfokot eredményezhet.

Mind az ékek, mind a gurigák esetén azt tapasztaltam, hogy a perzisztencia hossz tipikusan $100-1000 \mu \mathrm{m}$ nagyságrendben változott. Pontosan mit jelent ez? A megvilágítás geometriájához (pl.: nyalábátmérö) viszonyítva a perzisztencia hossz lényegesen, akár egy nagyságrenddel is nagyobb lehet. Ez azt jelenti, hogy olyan geometriájú mikrocsatornában, aminek méretei a perzisztencia hosszal összemérhetők, a mikrostruktúrák még szabályos iránytartó mozgásra lesznek képesek hasonló intenzitású megvilágítás hatására, mint amit a kísérleteimben alkalmaztam. Tekintve, hogy az struktúrák méretéhez viszonyítva 1-2 nagyságrenddel nagyobb a perzisztenciahossz, ez lehetővé teszi a mikrostruktúrákhoz képest igen nagy méretü mikrocsatorna alkalmazását is, ́́gy az általam vizsgált rendszer például alkalmas lehet autonóm mikrostruktúrák kollektív mozgásának vizsgálatára lényegesen nagyobb (akár mm-es) méretű mikrocsatornákban is. 


\subsubsection{Tézispont}

Mikroszkopikus, fénnyel hajtott autonóm módon mozgó guriga kivitelü testet készítettem, amelynek olyan az alakja, hogy a forgástengelyére merőlegesen érkező megvilágítás hatására gördülni kezd a helyzete által meghatározott irányban.

Ilyen, fotopolimerizációval előállított és aranyréteggel bevont 3 dimenziós gurigák mozgását vizsgáltam. A gurigák megvilágítására olyan optikai elrendezést alkalmaztam, amely alulról és felülről is megvilágította a gurigákat, ahol az alsó megvilágítás szerepe elsősorban a súrlódás csökkentetése volt. Kísérletekkel bebizonyítottam, hogy megfelelő alakú gurigák valóban képesek a fény által hajtott folyamatos forgásra, a megfelelő irányú mozgásra. [T2] 


\subsection{Fényindukált forgás általános feltétele}

A prizmaszerü gurigák esetén a szimulációk azt mutatták, hogy nincs olyan alakú struktúra, ami megvilágítás hatására stabil forgásra lenne képes. Az alábbiakban általánosan bebizonyítom, hogy veszteségmentes prizmaszerü struktúrák esetén nem lehetséges folyamatos forgást elérni.

A bizonyítás első lépéseként a probléma szögfüggését küszöböljük ki a fényforrás izotróp megvilágítással történő helyettesítésével. Ugyanis, amikor a forgatónyomatékot egy teljes körülfordulásra integráljuk - azaz a struktúrát egy adott irányból érkező párhuzamos sugarakkal kivilágítjuk és ebben a sugárzási térben elforgatjuk - ez ekvivalens azzal az esettel, mintha magát a fényforrást forgatnánk el a struktúra körül. Ez megfelel annak, mintha izotróp sugárzási térbe helyeznénk a struktúrát (a sugárzási tér bármely pontján minden irányból haladnak át sugarak).

Második lépésként a nyalábok jellemzésére bevezetem a radiancia fogalmát, ami az egységnyi felületen $(\partial A)$ áthaladó, egységnyi térszögben $(\partial \Omega)$ érkező teljesítmény $(P)$ :

$$
L=\frac{\partial^{2} P}{\partial A \partial \Omega}
$$

Az izotrópia miatt minden egyes sugár ugyanazzal a radianciával rendelkezik. Amennyiben a rendszer veszteségmentes, tehát nincs abszorpció, akkor a radiancia megmaradó mennyiség [143].

\subsubsection{Fényvisszaverö struktúra esete}

Egy beérkező fénysugár bizonyos számú visszaverődést követően elhagyja az objektumot, azonban mivel a rendszer veszteségmentes, a kilépő sugarak összradianciája nem változik meg. A kölcsönhatás során az egyes fénysugarak terjedési irányai megváltozhatnak a felszínen bekövetkező visszaverődés miatt, azonban a radiancia mindig változatlan marad. Mivel izotróp a sugárzási tér, minden kilépő sugárhoz tartozik egy ellentétes irányú sugár, aminek ugyanolyan lesz a radianciája, mint a kilépő sugárnak. Ebből következik, hogy a sugárzási tér a reflexiókat követően nem változik meg, nem adódik át sem impulzus sem impulzusmomentum az objektumnak, így a sugárzási térnek nincs mechanikai hatása az objektumra. Emiatt a forgató nyomatéknak egy teljes körülfordulásra vett integrálja mindig 0 lesz. 


\subsubsection{Atlátszó és veszteségmentes struktúra esete}

Átlátszó és veszteségmentes (nem fényelnyelő) objektum esetén a bizonyítás hasonlóan történik, aminek megértéséhez a 42. ábra ad segítséget.

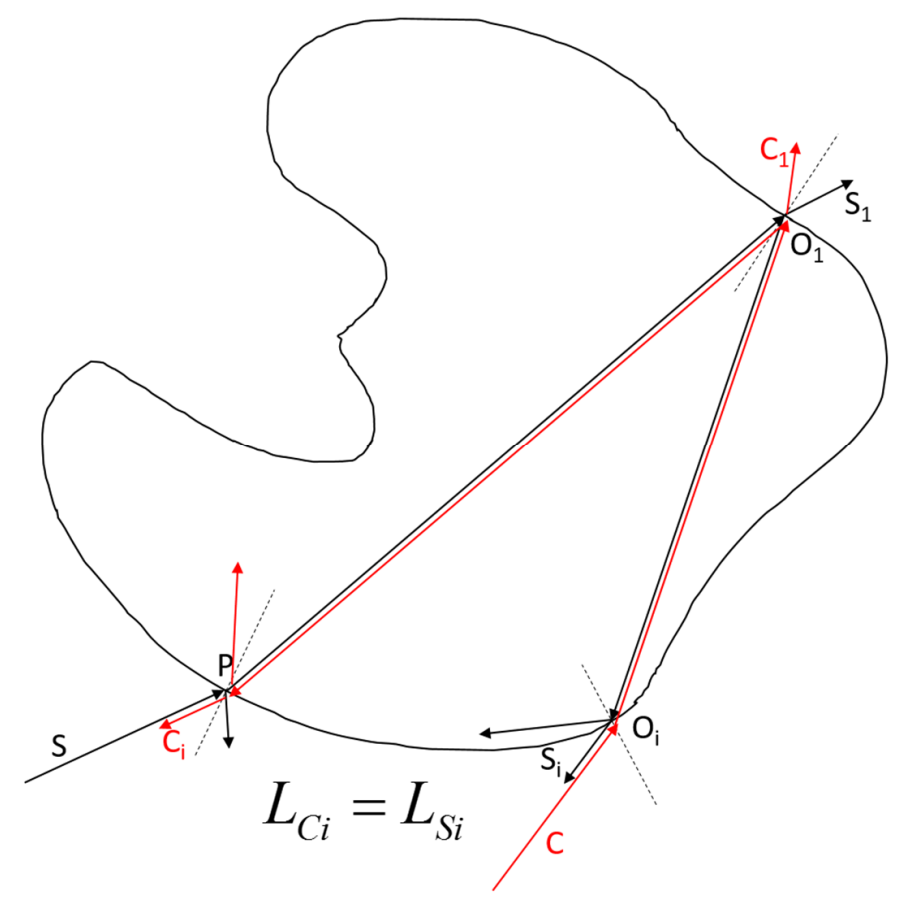

42. ábra A belépő $S$ nyaláb és egy szembe haladó $C$ nyaláb útja átlátszó struktúra esetén.

Tekintsünk egy infinitezimálisan kis keresztmetszeten beérkező sugarat $(S)$, ami a $P$ ponton érkezik a struktúrára és aminek a radianciája L. Az objektumon történő áthaladás során minden egyes felületen, amelyen áthalad a nyaláb, lejátszódik egy reflexió és egy törés, ami a nyalábot két részre bontja. Jelölje ezeket a törési pontokat $O_{i}$. Mind a visszavert, mind a megtört nyaláb tovább halad, és minden újabb felületen történő áthaladás tovább bontja a nyalábot. Ez addig tart, míg az összes résznyaláb $\left(S_{i}\right)$ el nem hagyja az objektumot. Minden alkalommal, amikor egy felülettel kölcsönhatás lép fel a résznyalábok radianciája a Fresnel egyenleteknek megfelelően változik meg. Végeredményben a kezdeti radiancia eloszlik az összes keletkezett résznyaláb között, amelyek elhagyják az objektumot:

$$
L=\sum_{i} a_{i} L
$$


ahol $a_{i}$ azt adja meg, hogy a kezdeti radiancia hányad részével rendelkezik az i résznyaláb. Mivel a sugárzási tér izotróp, minden egyes $S_{i}$ sugárral szembe halad egy L radianciájú sugárzás, amit jelöljön $C$, aminek belépési helye $O_{i}$. Ezen $C$ sugárnak egy része ugyanazon az optikai úton fog visszafelé haladni, mint amelyiken a $S_{i}$ sugár érkezett. A Fresnel egyenletek irányfüggetlensége miatta $P$ ponton ( $S$ belépő helyén) $\mathrm{C}$ nyaláb kilépő részének radianciája, amit jelöljön $C_{i}$ megegyezik az $S_{i}$ nyaláb radianciájával.

$$
L_{C i}=L_{S i}=a_{i} L
$$

Ha összegezzük minden egyes $S_{i}$ résznyalábbal szembe haladó nyaláb $P$ ponton kilépő részét, akkor azt kapjuk, hogy ezek összes radianciája megegyezik az $S$ nyaláb radianciájával:

$$
\sum_{i} L_{C i}=\sum_{i} L_{S i}=L
$$

Végeredményben minden $\mathrm{S}$ belépő nyalábhoz tartozik egy szemben haladó nyaláb, aminek radianciája megegyezik az $\mathrm{S}$ radianciájával, azonban az irányuk ellentétes. Ennek megfelelően átlátszó és veszteségmentes struktúra esetén sem változik meg a sugárzási térnek sem az impulzusa, sem az impulzusmomentuma, így a megvilágításnak nem lesz mechanikai hatása az objektumra.

Összefoglalva a prizmaszerű struktúrák esetén, ha a fényszórás veszteségmentesen (fényelnyelés nélkül) 2 dimenzióban történik, akkor az egész jelenség 2 dimenzióban játszódik le. Ekkor a struktúrák folyamatos forgásra nem képesek. Folyamatos forgás akkor valósulhat meg, ha a szórás során kikerül a fény a 2 dimenzióból - ami megvalósulhat akár szórással, akár abszorpcióval -, vagyis a kölcsönhatás 3 dimenziós lesz. 


\subsubsection{Tézispont}

Elméleti bizonyítását adtam, hogy a prizmaszerü struktúrák nem képesek a forgástengelyre merőlegesen érkező homogén megvilágítás hatására folyamatosan forogni. A bizonyításban központi szerepet játszik, hogy i) veszteségmentes (lineáris) optikai rendszerben a radiancia megmaradó mennyiség, ii) egy oldalról homogén módon megvilágítva a struktúrát és körbeforgatva mechanikai hatás szempontjából ekvivalens azzal esettel, mintha izotróp sugárzási térbe helyeznénk a struktúrát. A bizonyítást mind teljesen fényvisszaverō, mind pedig átlátszó struktúra esetére elvégeztem.

A megfigyelések és bizonyítások összegzéseként az alábbi általános állítást fogalmaztam meg: Szóró testtel kölcsönható, impulzusmomentumot nem hordozó kollimált nyaláb nem hozhat létre folyamatos forgást, ha a fényszórás kétdimenziós és a kölcsönhatás veszteségmentes. A fény hajtotta forgás szükséges, de nem elegendő feltétele, hogy a fényszórás 3 dimenziós legyen. [T2] 


\subsection{Hidrodinamikai szinkronizáció}

A mérésekben használt forgó rotorok mozgását kiértékelő szoftver az egyes rotorok pillanatnyi fázisait határozza meg. Ezen fázisértékek alapján a kumulatív fázis - a teljes fázis tartomány, amit a mérés kezdete óta a rotor bejárt - szintén meghatározható. A kumulatív fázis meghatározása során figyelembe kell venni, hogy hány teljes fordulatot ( $n$ ) végzett el a rotor, amihez a pillanatnyi fázis értékét $(\phi)$ kellett hozzáadni (amit egy adott képkocka kiértékelése során határoztam meg):

$\phi_{\text {cum }}=n \cdot 360^{\circ}+\phi$
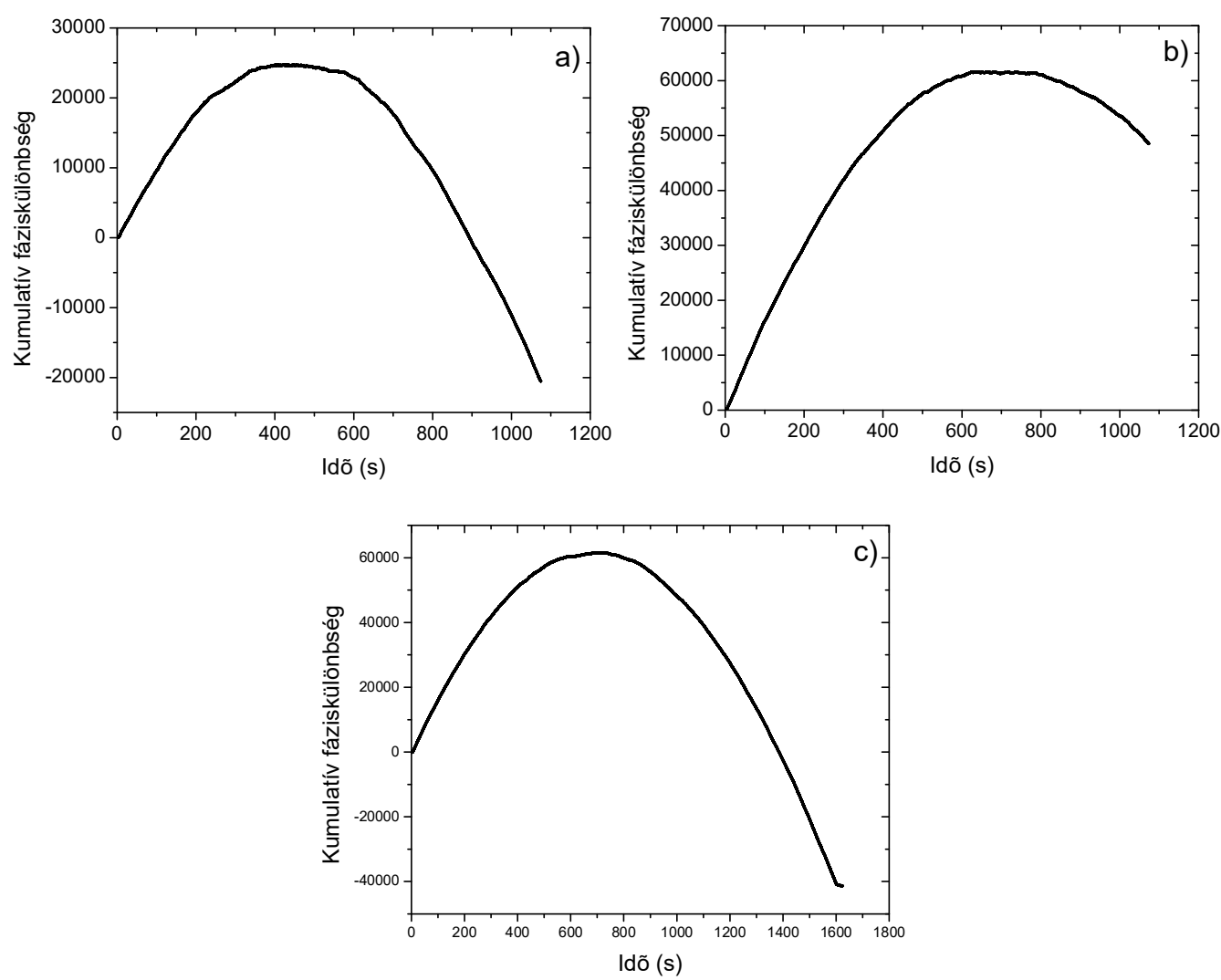

43. ábra A két rotor kumulatív fázisának különbsége $(\Delta \phi)$ az idő függvényében a) $6 \mu \mathrm{m}, \mathrm{b})$ $6.5 \mu \mathrm{m}, \mathrm{c}) 7 \mu \mathrm{m}$-es rotortávolságnál.

A rotorok fáziskülönbsége az egyik és másik rotorra kapott kumulatív fázisok különbsége:

$$
\Delta \phi=\phi_{c u m}^{j o b b}-\phi_{c u m}^{b a l}
$$


A rotorok kumulatív fázisának különbségét a 43. ábra mutatja 3 különböző - a) $6 \mu \mathrm{m}$, b) $6.5 \mu \mathrm{m}$ illetve c) $7 \mu \mathrm{m}$-es - rotortávolság esetén. Megfigyelhetö, hogy a fáziskülönbségek görbéi - a rotorok egymáshoz viszonyított forgási sebességeinek megfelelően - egy növekedési, közel állandó, és egy csökkenő szakaszból állnak. Mivel a kísérletek megkezdése előtt az egyenlő forgási sebesség meghatározása csupán hozzávetőlegesen történt, ezért az egyenlő sebeségű szakasz nem feltétlenül található a teljes vizsgált sebesség tartomány közepén.
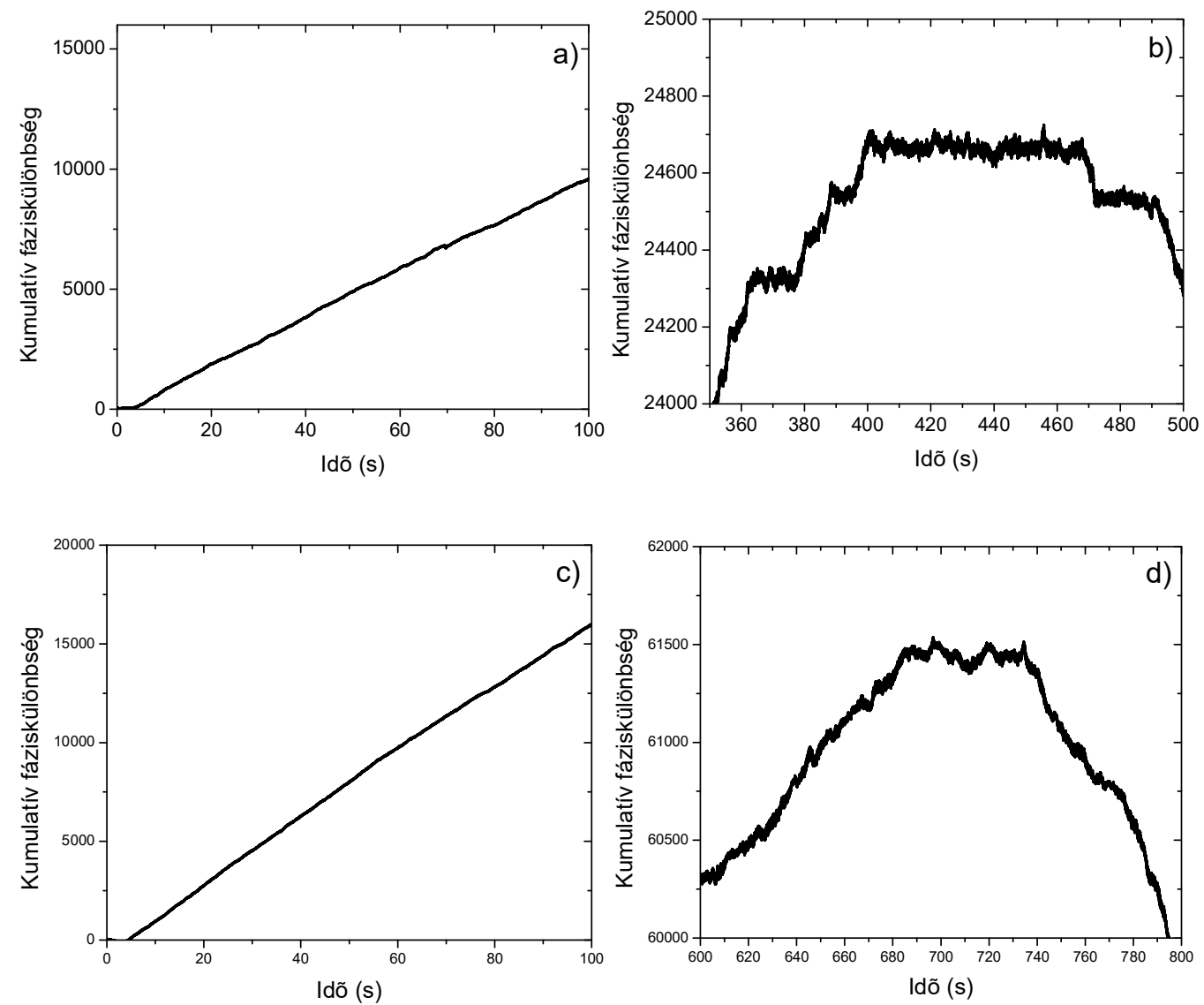

44. ábra Rotorok kumulatív fáziskülönbsége $(\Delta \phi)$, amikor a), c) különböző sebességgel forognak, illetve b), d) mikor közel egyenlő sebességgel forognak. A rotorok távolsága a felső a), b) ábrapár esetén $6 \mu \mathrm{m}$ míg az alsó c), d) ábrapár esetén $7 \mu \mathrm{m}$.

Abból a célból, hogy a láthatóvá váljon, miként jelenik meg a szikronizáció hatása különböző sebességviszonyok között, a 43. ábrán látható görbék egyes részeit nagyítva ábrázoltam, ez a 44. ábrán látható. Azon a szakaszon, ahol a rotorok forgási sebessége jelentősen eltér, ami a 44.a) és c) ábrán látható, a görbék jellegében nem látszik jelentős különbség a $6 \mu \mathrm{m}$-es és a $7 \mu \mathrm{m}$-es 
rotortávolságok között, mindkét esetben a kumulatív fáziskülönbség egyenletes változása figyelhető meg. Azon a szakaszon, ahol a rotorok sebessége közel egyenlő, ami a 44.b) és d) ábrán látható, mindkét rotortávolság esetén platók kialakulása figyelhető meg a görbéken. Ez a plató a fáziscsatolást, azaz a hidrodinamikai szinkronizációt demonstrálja. A $6 \mu \mathrm{m}$-es rotortávolságnál az erősebb csatolás következtében a platók megjelenése sokkal szembetünőbb, mint a $7 \mu$ m-es rotortávolságnál. A fáziscsatolt állapotban a fáziskülönbség jól meghatározott értékek körül változik. Időnként a platók között átmenetek jellenek meg, ekkor a fáziskülönbségek ugrásszerüen megváltoznak, és ez okozza a fáziskülönbség „lépcsőzetes” változását. A platók közötti $120^{\circ}$-os távolság összhangban van a rotorok $120^{\circ}$-os szimmetriájával, ami arra utal, hogy a szinkronizáció során a két rotor egymáshoz képest mindig ugyanabban az elrendezésben rögzül.
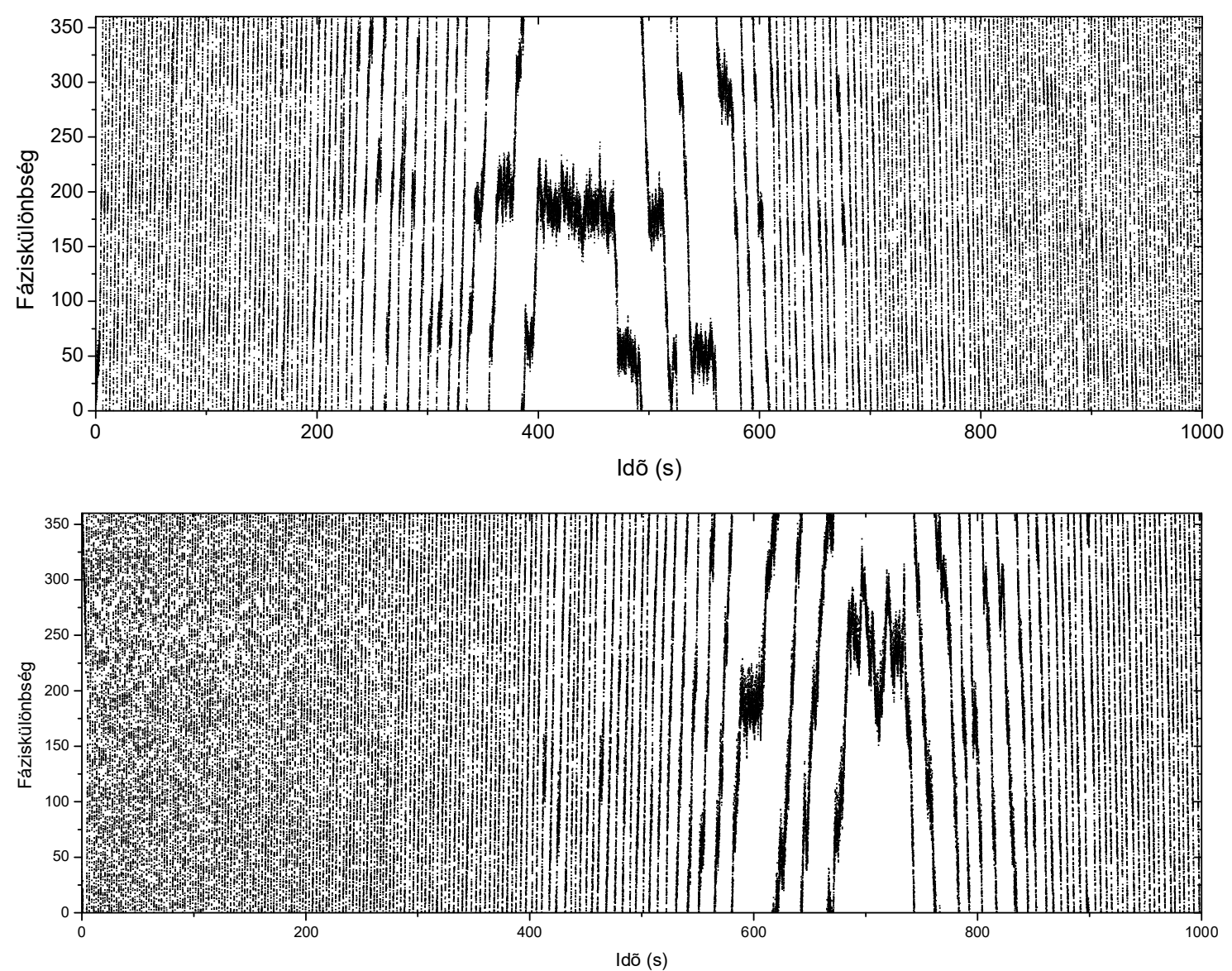

45. ábra A $\phi_{\bmod 360}$ függvény $6 \mu \mathrm{m}$ (felső ábra) és $7 \mu \mathrm{m}$ (alsó ábra) rotortávolság esetén.

Bár a rotorok $120^{\circ}$-os szimmetriával rendelkeznek, először célszerü megvizsgálni a fáziskülönbségek modulo $360^{\circ}$-kal vett ábrázolását: 


$$
\phi_{\bmod 360}=\bmod (\Delta \phi, 360)
$$

amit a 45. ábra mutat be. Ebben az ábrázolásban egyértelműen látszik a szinkronizáció hatása, azaz ahogy közeledve az egyenlő sebességü szakaszhoz, három tartomány/sáv jelenik meg kb. $60^{\circ}$, $180^{\circ}$ és $300^{\circ}$-nál, ahol a két rotor forgása csatolódik. Az egyenlő sebességü szakasztól távolodva - a sebességkülönbségek növelésével egyre gyakoribb a szinkronizált állapotból történő kilépés.

Az 46. ábrán figyelhető meg a rotorok egymáshoz viszonyított helyzete a $60^{\circ}, 180^{\circ}$ és $300^{\circ}$-os fáziskülönbségnek megfelelő fáziscsatolt állapotban, ami a tükörszimmetrikus elrendezésnek felel meg. Fontos megjegyezni, hogy az ábra egy pillanatképet mutat, hiszen a rotorok folyamatosan forognak, az orientációjuk folyamatosan változik, de szinkronizáció során a tükörszimmetria gyakorlatilag minden orientációban megmarad. A két rotornak összesen három különböző állapota van, amikor a tükörszimmetriának megfelelő állapot beáll és a $60^{\circ}$, $180^{\circ}$ és $300^{\circ}$-os fáziskülönbségek mindhárom lehetséges állapotot lefedik.

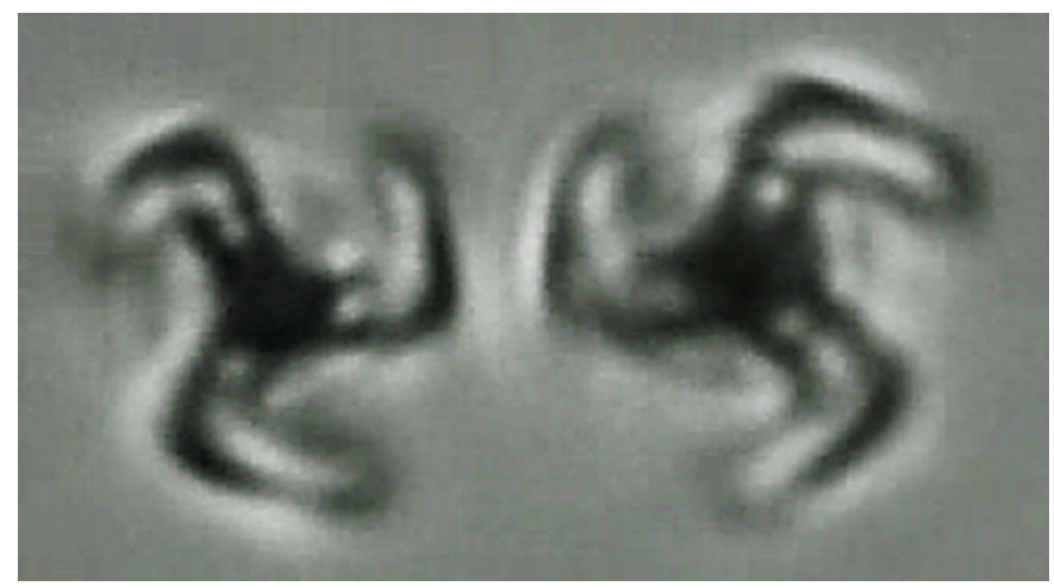

46. ábra A szinkronizált állapotot bemutató pillanatkép.

A 45. ábra csupán az egyenlő sebességü szakaszokra vonatkozóan szolgáltat hasznos információkat a rotorok viselkedéséről, mivel a nem egyenlő sebességü szakaszokon a nagyon sürün elhelyezkedő pontok miatt az ábra nehezen értelmezhető. Annak érdekében, hogy a nem egyenlő sebességü tartományok is áttekinthetők legyenek, hisztogramon ábrázoltam a fáziskülönbségek előfordulási gyakoriságát $0^{\circ}$ és $360^{\circ}$ közötti szögtartományban a teljes mérésre vonatkozóan (47.a és c ábra), illetve a kumulatív fáziskülönbségek növekvő, állandó és csökkenő szakaszán is (47.b és d ábra). 

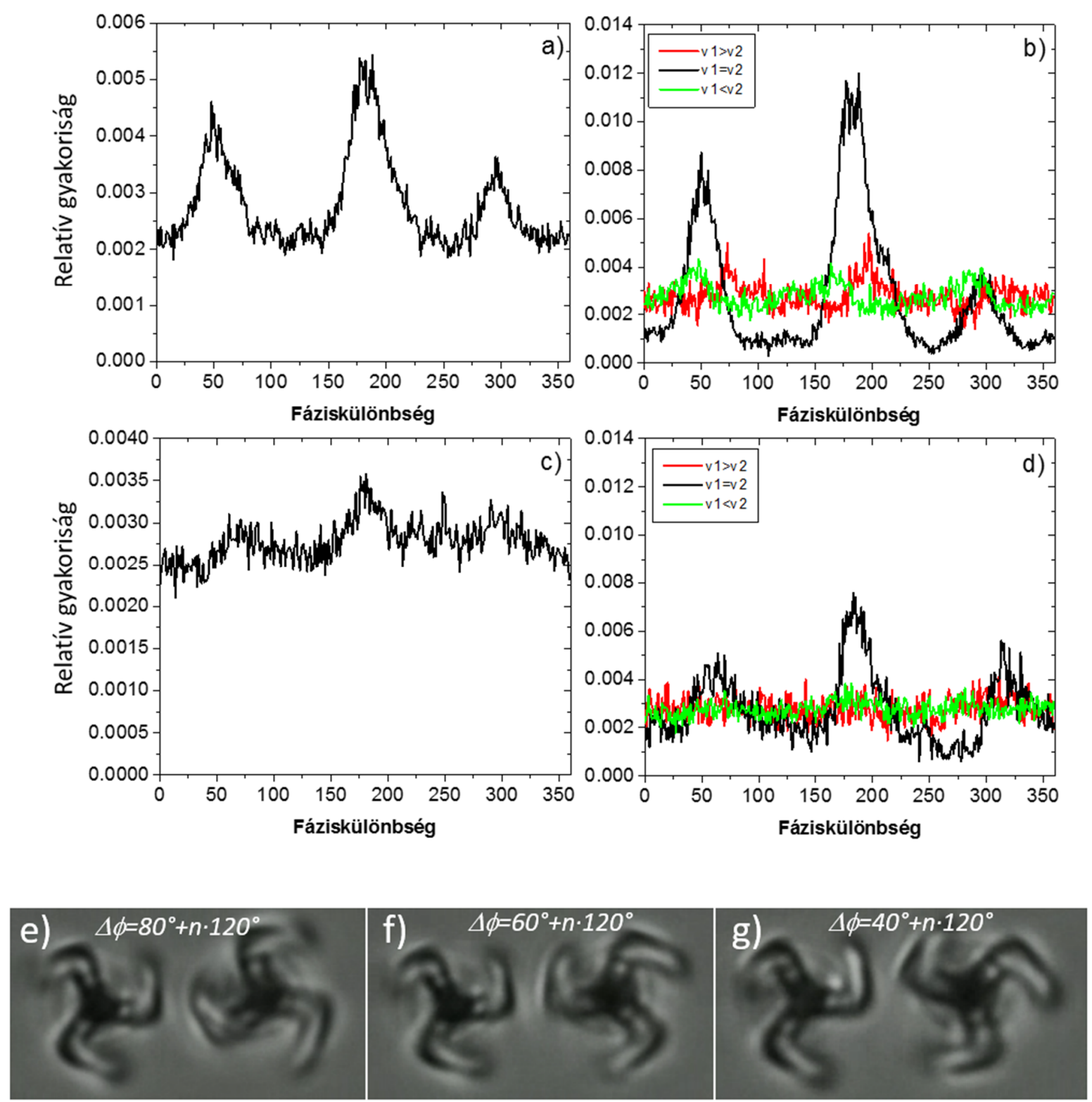

47. ábra A kumulatív fáziskülönbségek $360^{\circ}$-kal vett modulojának hisztogramja a teljes mérésre vonatkozóan a) $6 \mu \mathrm{m}$ és c) $7 \mu \mathrm{m}$ rotortávolság esetén és illetve szakaszos kiértékelés b) $6 \mu \mathrm{m}$ és d) $7 \mu \mathrm{m}$ rotortávolság esetén. A különböző sebességviszonyokhoz tartozó hisztogramok maximumainak megfelelő orientációkat e), f), g) ábra mutatja, amikor a jobb oldali rotor szögsebessége nagyobb, a forgási sebességek egyenlők, illetve a bal oldali rotor szögsebessége nagyobb.

A hisztogramok határozottan alátámasztják, hogy a rotorok csatolódása $60^{\circ}, 180^{\circ}$ és $300^{\circ}$-nál valósul meg (47.a) és c) ábra). A különböző sebességű tartományok vizsgálatával még az is 
megállapítható, hogy a hisztogramokon jóval az egyenlő sebességü tartományon túl is csúcsok jelennek meg fenti szögek körüli tartományban, vagyis a csatolás ott is megvalósul. Ez leginkább $6 \mu \mathrm{m}$-es rotortávolságnál figyelhető meg, ahogy azt a 47.b) ábra is mutatja. A hisztogramok segítségével az is megállapítható, hogy a csúcsok maximuma eltolódik, a kumulatív fáziskülönbségek növekvő ágában $60^{\circ}$ fölé, amit a 47.b) ábrán a piros görbe mutat, míg a csökkenő ágban $60^{\circ}$ alá, ami a 47.b) ábra zöld görbéjén figyelhető meg. $7 \mu$ m-es rotortávolságnál ez a viselkedés már nem mutatható ki.

A 47. ábrán az is megfigyelhetö, hogy a megjelenő három $\left(60^{\circ}, 180^{\circ}\right.$ és $300^{\circ}$-hoz tartozó) csúcs magassága eltérő. Ez a viselkedés valószínűleg a rotorok aszimmetriájának a következménye, ami miatt egyes elrendezésekben stabilabb a csatolódás, mint másokban. Azonban e jelenség pontosabb vizsgálatához hosszabb mérésekre lett volna szükség.

Összegezve megállapítható, hogy nincs lényegi eltérés a rotorok különböző elrendezésben történő csatolódása között, azaz minden esetben tükörszimmetriájú elrendezésben csatolódnak (a kumulatív fáziskülönbség $60^{\circ}+\mathrm{n} \cdot 120^{\circ}$, ahol $\left.\mathrm{n}=1,2,3\right)$, illetve a szinkronizációhoz tartozó fáziskülönbségek eltolódása megegyező irányú mindhárom elrendezésben. Emiatt a két rotor három elrendezése ekvivalensnek tekinthető és például ennek megfelelően a továbbiakban $120^{\circ}$ os modulóval is vizsgálható:

$$
\phi_{\bmod 120}=\bmod (\Delta \phi, 120)
$$

A hisztogramok vizsgálata fontos információkat szolgáltat a szinkronizáció folyamatáról, sőt még a jelentős sebességkülönbségü tartományban is - ahol nincs szinkronizáció - rendkívül hasznosnak bizonyult. Annak érdekében, hogy átfogó képet kapjunk a rotorok viselkedéséről a szinkronizáció előtt, közben és után, a teljes mérést egyenlő hosszúságú különálló tartományokra osztottam fel és minden tartománynak meghatároztam a hisztogramját. Egy szakasz hossza 2000 mérési pontnak felel meg, ami egy ciklust foglal magába (egy cikluson belül a sebességarányokat fixen tartjuk). Ezeket a hisztogramokat időrendben egymás mellé helyezve egy olyan kép nyerhető, amely a hisztogramok változását mutatja a sebességarányok változásának függvényében, ahogy azt a 48. ábrán lehet megfigyelni. 

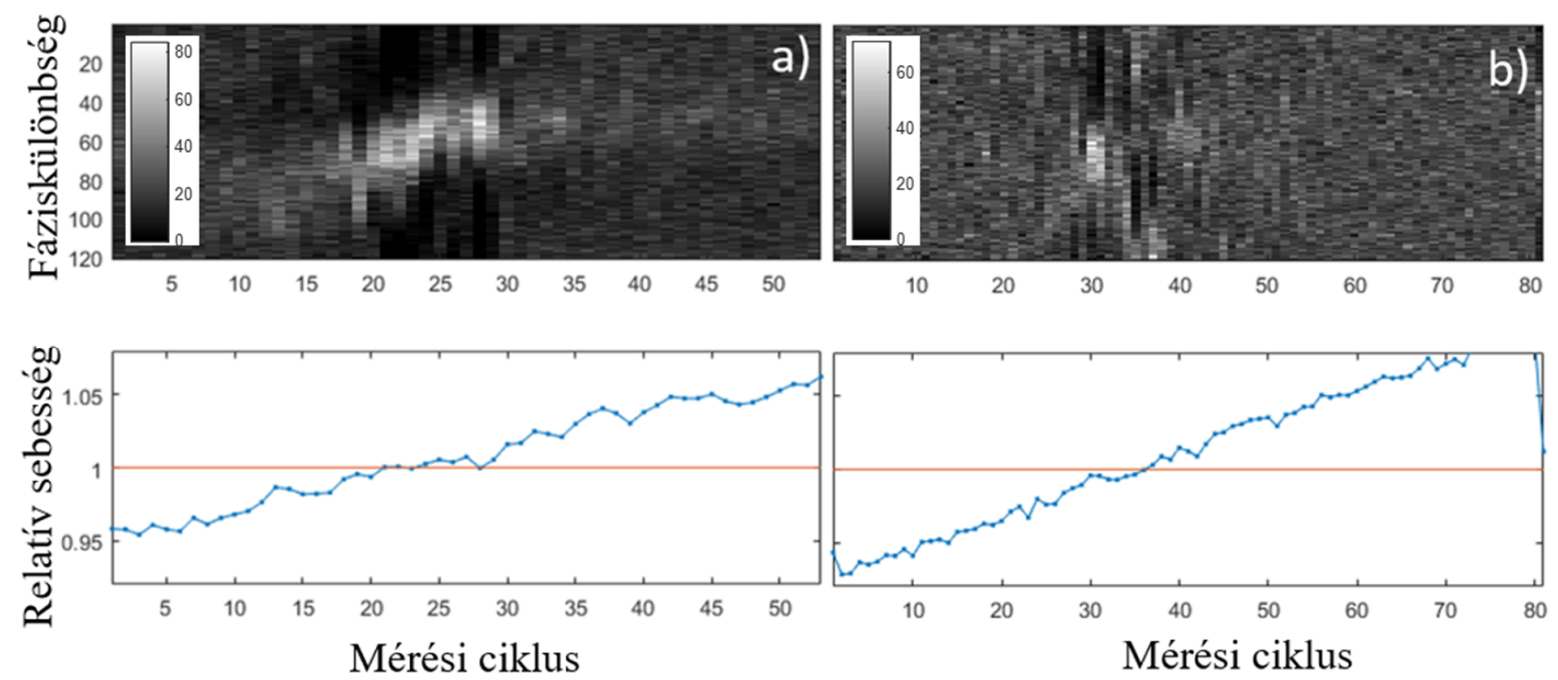

48. ábra Az ábrapárok felső ábráin az egyes fáziskülönbségek előfordulási gyakorisága, az alsó ábráin a sebességarányok láthatók az egyes mérési tartományokban a) $6 \mu \mathrm{m}$, b) $7 \mu \mathrm{m}$-es rotor távolságok esetén. Az egyes tartományok hossza 2000 mérési pont, ami egy mérési ciklusnak felel meg.

A hisztogram sorozatokon jól megfigyelhető, hogy a szinkronizációhoz tartozó fáziskülönbségek eloszlásának maximuma $\mathrm{kb} .60^{\circ}$-nál jelenik meg, azonban a sebességarányok változtatásával ez az érték folyamatosan eltolódik. Az eltolódás a teljes mérés alatt kb. $80^{\circ}$-tól $40^{\circ}$-os fáziskülönbség értékig történik, miközben a sebességviszonyok teljesen átfordulnak - kezdetben amelyik rotor gyorsabb volt, a mérés végén már lassabb. Az eltolódás határértékeit a forgási frekvenciák viszonylag kismértékü elhangolásánál - kb. 0.98 és 1.02 frekvenciaarányoknál - eléri. A hisztogramok alatti ábrán látható az adott tartományon az átlagfrekvenciák arányának változása a mérés során, ami segítségével megállapítható, hogy a stabil szinkronizációhoz tartozó frekvenciaarányok 0.99 és 1.01 között változnak (ami kisebb, mint 1\%-os eltérésnek felel meg). A forgási frekvenciák 1\%-nál nagyobb eltérése esetén már nem figyelhető meg stabil fáziscsatolás.

A mérés során az eloszlások szélessége is változik. A szinkronizált állapothoz tartozik a legkeskenyebb eloszlás, aminek alakja Gauss-szerü függvénnyel jól közelíthető, és aminek félértékszélessége $\mathrm{kb} .15^{\circ}$. A sebességek változtatása során az eloszlások szélessége fokozatosan növekszik és az eloszlások alakja fokozatosan átmegy Gauss-szerü eloszlásból egyenletes 
eloszlásba. Kb. 0.98 - 1.02-es sebességaránynál (ami kb. 2-3\%-os sebességkülönbségnek felel meg) a fáziskülönbségek eloszlása szinte teljesen homogén. Maga az eltolódás csak a $6 \mu$ m-es rotor távolságoknál figyelhető meg. Más rotortávolságok esetén kizárólag a szinkronizáció figyelhető meg egy rendkívül szűk sebességtartományban, ahogy azt a 48.b ábra is mutatja $7 \mu \mathrm{m}$ es rotortávolság esetén.

A fenti mérést többször is megismételtem különböző rotorpárokkal, és minden esetben hasonló viselkedést tapasztaltam. Eltérés a szinkronizációhoz tartozó fáziskülönbségek eloszlásának maximumában mutatkozott, ugyanis nem minden esetben volt $60^{\circ}$-nál az eloszlás maximuma, hanem tipikusan $40^{\circ}$ és $90^{\circ}$ fok között változott. Ennek egyik oka lehet, hogy a szinkronizációhoz tartozó fáziskülönbség függhet a rotorok alakjától és a csapda minőségétől. Bár a kétfotonos polimerizáció jól reprodukálható struktúrákat eredményez, kismértékủ eltérések felléphetnek az egyes struktúrák előállítása során - például a rotorok karjainak hossza, vagy a tengelyek hossza nem egyforma, stb... -, ez okozhatja a fáziscsatoláshoz tartozó fáziskülönbség eltolódását a különböző kísérletekben.

A hisztogramok fenti vizsgálata rávilágít arra a tényre is, hogy az a hatás, ami a szinkronizációt létrehozza, nem csak az egyenlő sebességü tartományon fejti ki hatását. Jelentősebb sebességkülönbség esetén, ahol már egyáltalán nem beszélhetünk szinkronizációról, még mindig megfigyelhető kölcsönhatás a rotorok között, melynek hatása abban nyilvánul meg, hogy a fáziskülönbségek eloszlása nem lesz egyenletes. 


\subsubsection{A szinkronizáció potenciál modellje}

A rotorok szinkronizációjának modellezésére a 1.3.4. fejezetben is leírt analitikus modellhez hasonlót alkalmaztam. Az eredeti modellben két mikrogyöngy körpályán történő mozgását vizsgálták, ahol a gyöngyök közötti távolság a gyöngyök méretéhez, illetve a mozgás pályájának geometriájához képest nagy volt. Ekkor az egy teljes ciklusra vett fáziskülönbségek átlagára az alábbi mozgásegyenlet írható fel:

$$
\frac{\partial \varphi}{\partial t}=R\left[-\frac{d U(\varphi)}{d \varphi}+\Delta M\right]
$$

ahol $\varphi$ a fáziskülönbségek egy teljes ciklusra vett átlaga, $\Delta M$ a nyomatékok abszolút értékének különbsége, $R$ a rotációs mobilitás, $U$ a hidrodinamikai kölcsönhatást (és annak teljes komplexitását) egy olyan potenciállal leíró tag, ami a $\varphi$-nek periodikus függvénye.

Bár a két rotoros rendszerhez viszonyítva a fenti modell túl egyszerüsítettnek tünik, az értekezésemben nem részletezett numerikus szimulációink igazolják [T3], hogy rotorok esetén, ahol az egyes rotorok 17 mikro gyönggyel vannak helyettesítve, a fáziskülönbségek változását leíró egyenletek formailag megegyeznek a (80) egyenlettel. Ezen felül a fenti egyenlet még abban az esetben is helyesnek bizonyult, amikor a rotorok közötti távolság olyan kicsi, mint ami a kísérletekben is megvalósult. Így a fenti összefüggés rotorokra is alkalmazható és egy $\eta$ fluktuációt leíró tag hozzáadásával a sztochasztikus Adler egyenlet alakjában írható fel:

$$
\frac{\partial \varphi}{\partial t}=R\left[-\frac{d U(\varphi)}{d \varphi}+\Delta M+\eta\right]
$$

ahol igaz

$$
\begin{aligned}
& \langle\eta(t)\rangle=0 \\
& \langle\eta(0) \eta(t)\rangle=2 A \delta(t)
\end{aligned}
$$

A (81) dinamikai egyenlet megoldása a fáziskülönbségek olyan stacionárius valószínűségi eloszlását eredményezi, ami formálisan az alábbi Fokker-Planck egyenlet megoldásával nyerhetö, ahol periodikus peremfeltételt alkalmazunk:

$$
P(\varphi)=\frac{1}{Z} e^{-\beta U(\varphi)} \int_{\varphi}^{\varphi+\frac{2 \pi}{3}} e^{\beta\left[U\left(\varphi^{\prime}\right)-\Delta M\left(\varphi^{\prime}-\varphi\right)\right]} d \varphi^{\prime}
$$


ahol $\beta=1 / R A$ és $Z$ normálási faktor, amit a $\int_{\varphi}^{\varphi+2 \pi} P(\varphi) d \varphi=1$ feltétel határoz meg. Amikor a nyomatékok megegyeznek $(\Delta M=0)$, megfelel egy periodikus potenciálban végzett Brown fluktuációnak, és a (83) egyenlet Boltzmann eloszlásra egyszerüsödik:

$$
P(\varphi) \propto e^{-\beta U(\varphi)}
$$

Ez közvetlen lehetőséget ad arra, hogy a potenciál alakját a kísérleti adatokból meghatározzuk. Ha a mérésekből kapott eloszlások között be tudjuk azonosítani azt, ahol a nyomaték egyenlő amelyik a leghangsúlyosabb csúccsal rendelkezik a $P(\varphi)$ eloszlások közül - akkor a potenciált az alábbi módon kapjuk meg:

$$
\beta U(\varphi)=-\ln [P(\varphi)]
$$

A potenciál meghatározásakor figyelembe kell venni, hogy a kísérletileg mért hisztogram $H(\varphi)$ nem azonos a fent definiált $P(\varphi)$ valószínüségi eloszlással. A $\varphi$ fáziskülönbséghez tartozó $H(\varphi)$ gyakoriságot a $P(\varphi)$ valószínűségi eloszlás $\varphi$ fáziskülönbség körüli $\varphi-\Delta \varphi / 2$ és $\varphi+\Delta \varphi / 2$ tartományba eső integrálja adja:

$$
H(\varphi)=c \int_{\varphi-\frac{\Delta \varphi}{2}}^{\varphi+\frac{\Delta \varphi}{2}} P(\varphi) d \varphi \approx c P(\varphi) \Delta \varphi
$$

ahol $\Delta \varphi=2 \pi / 3 M, \mathrm{M}$ azt adja meg, hány pontban vizsgáljuk a hisztogramot, c pedig normálási faktor, hogy a

$$
\sum_{i=1}^{M} H_{i}=\sum_{i=1}^{M} H(i \Delta \varphi)=N
$$

feltétel teljesüljön. $\mathrm{N}$ a mérési pontok száma, amiből következik, hogy $c=N$ és

$$
P(\varphi)=\frac{1}{N} \frac{H(\varphi)}{\Delta \varphi}=\frac{3 M}{2 \pi N} H(\varphi)
$$

A fenti eljárást követve az egyenlő nyomaték esetén érvényes hisztogram segítségével a potenciál meghatározható, ami a 49. ábrán látható. 

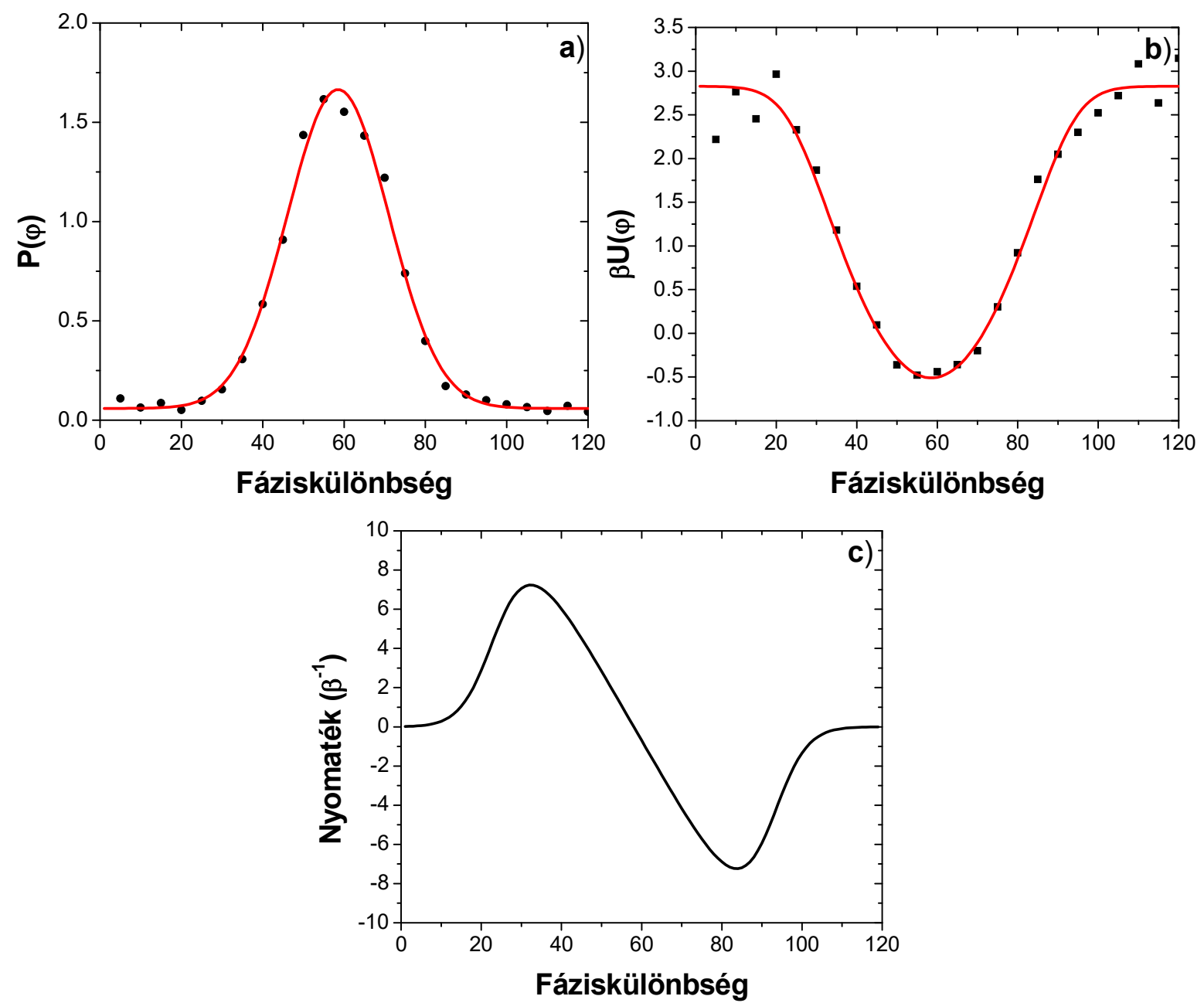

49. ábra $\mathrm{Az}$ egyenlő frekvenciához tartozó hisztogramból származtatott $P(\varphi)$ valószínűségi eloszlásfüggvény a) a hozzá tartozó $U=-\ln (P(\varphi))$ potenciál b) és a $M=-\partial U(\varphi) / \partial \varphi$ nyomaték a fáziskülönbség függvényében.

A potenciálgát maximuma $\beta^{-1}$ egységekben van számolva. A szinkronizáló nyomatékot a potenciál negatív gradiense adja:

$$
M=-\frac{d U(\varphi)}{d \varphi}
$$

aminek a maximuma $M_{c}=7 \beta^{-1}$. Ha feltételezzük, hogy minden zaj a termális fluktuációkból ered, akkor az várható, hogy $\beta^{-1}$ a $k_{b} T=4 \times 10^{-3} p N \mu m$ nagyságrendjébe esik. Ekkor a maximális szinkronizációs nyomaték $M_{c} \sim 3 \times 10^{-2} \mathrm{pN} \mu \mathrm{m}$, ami felett nincs stabil szinkronizáció. Annak érdekében, hogy össze tudjuk vetni a szinkronizációs nyomatékot a gurigákat meghajtó 
nyomatékkal, megbecsültem az utóbbi értékét. A rotorok forgási frekvenciája az értekezésben bemutatott kísérletekben $\mathrm{kb} . f=6.39 \mathrm{~Hz}$ volt. A szögfrekvencia $\Omega=R M$, ahol $\mathrm{R}$ a rotorok rotációs mobilitása, M az alkalmazott nyomaték. Numerikus szimulációink alapján [T3] a rotorok rotációs mobilitása megbecsülhető: $\mathrm{R}=5.3(\mathrm{pN} \mu \mathrm{m} \mathrm{s})^{-1}$. Ez alapján a rotorokra ható nyomaték $\mathrm{M}=7.57 \mathrm{pN} \mu \mathrm{m}$ volt. A szinkronizációs nyomaték nagyságrendileg ennek a nyomatéknak 1/1000 része, ami konzisztens azzal a tapasztalattal, hogy az intenzitás és sebesség arányok rendkívül finom állítására volt szükség a szinkronizáció észleléséhez.
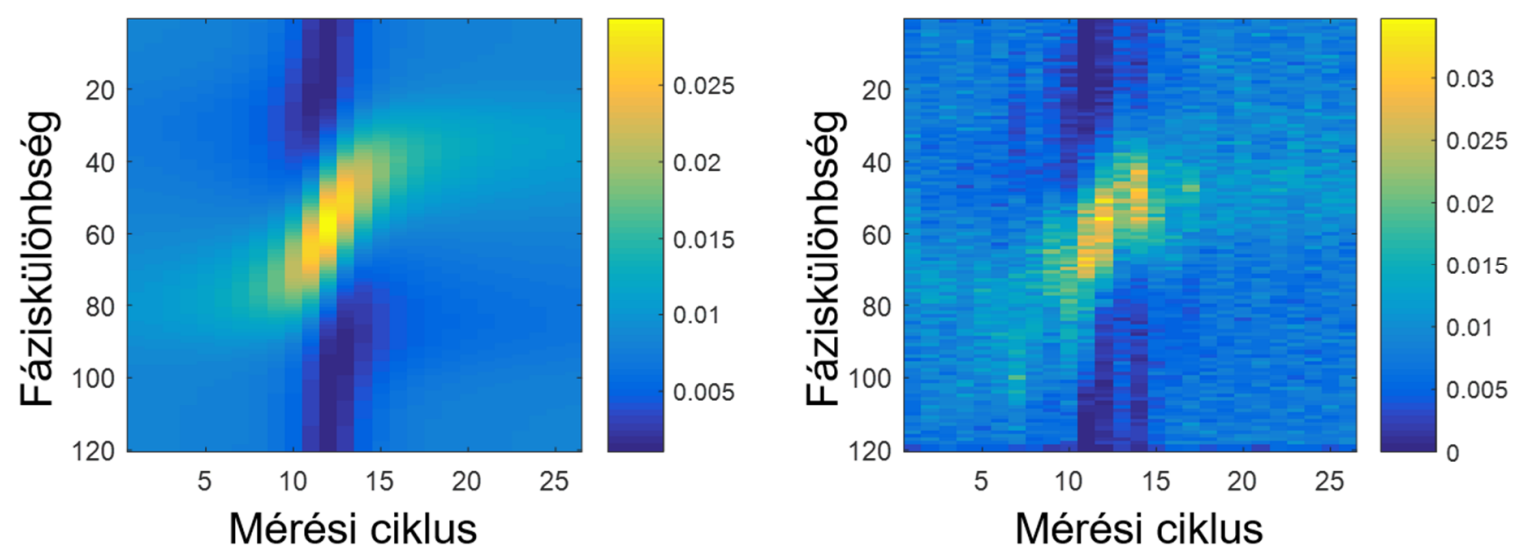

50. ábra Az illesztett a) és mért hisztogramok b). Egy hisztogram két mérési ciklust foglal magába.

Az egyenlő nyomatékhoz tartozó potenciált fel tudjuk használni arra, hogy a nem egyenlő nyomaték esetén is meghatározzuk a potenciál alakját. Az alkalmazott nyomatékok pontos értékét nem ismertem, azonban az feltételezhető, hogy a nyomatékok változtatása közel azonos lépésekben történt, ahogy a 50. ábrán is megfigyelhető a sebességek lineáris változása:

$$
\Delta M=\Delta M_{0} i
$$

ahol $i$ egész szám. Így az egyetlen szabad paraméter a $\Delta M_{0}$, vagy ha visszaírjuk a (83) egyenletbe, akkor az $\alpha=\beta \Delta M_{0}$. Az $\alpha$ paraméter meghatározása illesztés segítségével történik. A (83) egyenletből számolt eloszlások kísérletekböl származó hisztogramokra történő illesztésével, amit az 50. ábrán láthatunk, adódik, hogy $\alpha=1.44$. Az $\alpha$ ismeretében a teljes $U-\Delta M \varphi$ döntött potenciál rekonstruálható, ami az 51. ábrán látható. A hisztogramok maximumának $60^{\circ}$-hoz képest történő eltolódása a potenciálgödör minimumának (ahol van) eltolódásával magyarázható. 


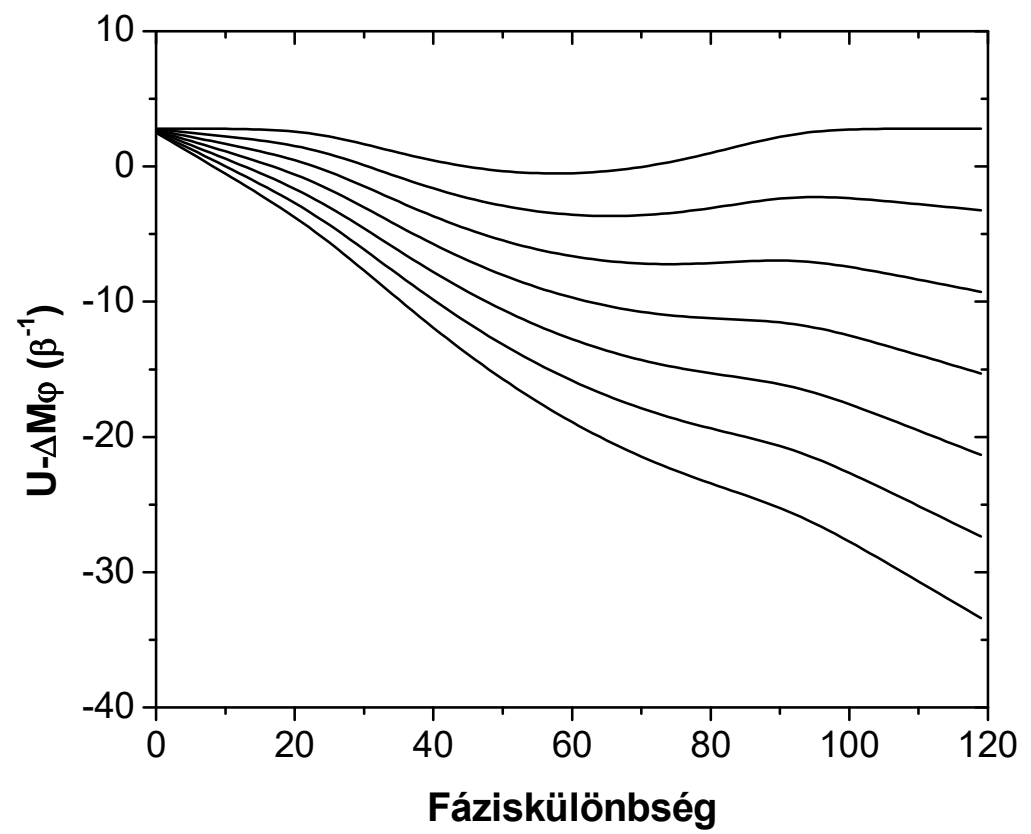

51. ábra A potenciál változása a frekvenciák elhangolása során (a bemutatott görbékre

$$
\mathrm{i}=0,2,4,6, \ldots) \text {. }
$$

\subsubsection{A szinkronizáció távolságfüggése}

A fent bemutatott eredmények elsősorban $6 \mu \mathrm{m}$-es rotortávolságra vonatkoznak. Kísérleteimet különböző rotortávolságokban is megismételtem, ahol a rotortávolságot $6.0 \mu \mathrm{m}$ és $7.0 \mu \mathrm{m}$ között változtattam. A távolságfüggés vizsgálata során igen eltérő tapasztalataim voltak. Egyrészt volt olyan eset, ahol a rotorok közötti távolság $1 \mu \mathrm{m}$-rel történő növelése elegendő volt, hogy a jelenség alig észlelhető legyen. Ezzel szemben bizonyos esetekben még $7 \mu \mathrm{m}$-es rotortávolság mellett is jól megfigyelhető volt a jelenség. A mérések közötti jelentős eltérések két okból is adódhatnak:

Az egyik lehetséges ok, ahogyan az optikai csapda és a struktúrák közötti kölcsönhatás megvalósul. A kölcsönhatást nagymértékben meghatározza a csapdázó nyaláb minősége (aberrációk, polarizáció), illetve a csapdázott struktúra szabályossága (szimmetriája, anyagának homogenitása). A gyakorlatban sem a nyaláb, sem a struktúra nem tökéletes, ami miatt a csapdázás során a struktúra nem a szimmetria tengelye mentén csapdázódik, illetve gyakran megbillen, vagy eltolódik a csapdához képest. Ennek következménye lehet, hogy a tényleges rotortávolság kis mértékben eltér a beállított (elérni kívánt) értéktől. 
A másik lehetséges ok a struktúrák reprodukálhatósága a fotopolimerizáció során. A kísérleteim során is tapasztaltam, hogy egyszerre polimerizált rotorok között is szemmel látható méretkülönbségek voltak. Emiatt még ha a rotortávolság pontosan van is beállítva, az eltérő méretek miatt a rotorok közötti folyadékréteg szélessége változó lehet.

Mivel a szinkronizáció nagyon függ a rotorok közötti távolságtól (illetve a közöttük lévö folyadékrétegtöl), mindkét folyamat nagy bizonytalansághoz vezet. Emiatt a rendszer pontos távolságfüggés vizsgálatára nem alkalmas, csupán annyi állapítható meg, hogy a szinkronizáció a távolság növelésével nagyon gyorsan lecseng. 


\subsubsection{Tézispont}

Demonstráltam, hogy a hidrodinamikai kölcsönhatás képes vízbe merülő mikrorotorok forgását szinkronizálni. A kísérleti demonstrációban optikai csipesszel csapdázott két mikrorotor forgását elemeztem nagyon finoman szabályozott paraméterek (forgási sebesség, a rotorok egymástól mért távolsága, stb.) mellett.

Analitikus modellt dolgoztam ki a szinkronizáció modellezésére. A rotorok fáziskülönbségének dinamikáját a sztochasztikus Adler egyenlet megoldásával modelleztem, ami egy Brown részecske mozgását írja le egy döntött potenciál gödörben. A két rotor forgási fáziskülönbségeinek eloszlását a Fokker-Planck egyenlet megoldásával nyertem. [T3] 
Tézisek alapját képező saját közlemények jegyzéke:

T1. A. Búzás, L. Kelemen, A. Mathesz, L. Oroszi, G. Vizsnyiczai, T. Vicsek, P. Ormos, Light Sailboats: Laser driven autonomous microrobots, Applied Physics Letters 101, 04111 (2012)

T2. L. Oroszi, A. Búzás, P. Galajda, L. Kelemen, A. Mathesz, T. Vicsek, G. Vizsnyiczai and P. Ormos: Dimensionality constraints of light-induced rotation, Applied Physics Letters 107, 204106 (2015)

T3. R. Di Leonardo, A. Búzás, L. Kelemen, G. Vizsnyiczai, L.Oroszi, and P. Ormos, Hydrodynamic Syncronization of Light Driven Microrotors, Physical Review Letters 109, 034104 (2012) 


\section{Köszönetnyilvánítás}

Ezúton szeretnék hálás köszönetet mondani témavezetömnek Dr. Ormos Pálnak, aki munkám végig figyelemmel kísérte és szakmai tanácsaival, biztatásával, barátságával mindvégig támogatott, és biztosította számomra azt a közeget, amiben sikeresen tudtam kutatómunkát végezni.

Szeretném megköszönni Dr. Zimányi Lászlónak, aki intézet igazgatóként lehetővé tette, hogy a SZBK Biofizika Intézetében végezhessek kutatómunkát.

Köszönöm Dr. Kelemen Lórándnak, Vizsnyiczai Gasztonnak és Dr. Badri L. Aekbotenak a minták előkészítésében nyújtott segítségét. Külön köszönöm Kelemen Lórándnak, hogy számos alkalommal szakított időt a konzultációinkra és Vizsnyiczai Gasztonnak a programozási nehézségek leküzdésében nyújtott segítségéért.

Köszönetet mondok Dr. Oroszi Lászlónak a gurigák mozgásának szimulációjáért, és hogy számos alkalommal fordulhattam hozzá szakmai segítségért.

Köszönöm Dr. Dér Andrásnak a szakmai diszkussziókat, amivel sok esetben új lendületet adott a munkámnak.

Köszönettel tartozok Dr. Galajda Péternek, gurigák mozgásával kapcsolatos bizonyításban nyújtott segítségéért.

Dr. Roberto di Leonardo-nak köszönetet mondok szakmai tanácsaiért, amivel a rotorok szinkronizációjának megértésében nyújtott segítséget.

Köszönöm Dr. Vicsek Tamásnak a perzisztencia modellek kidolgozásában nyújtott segítségét.

Köszönöm Imre Zoltánnak, aki a kutatásomhoz szükséges mühelymunkákat a lehetö legprecízebben végezte el.

Köszönetet mondok Dr. Geretovszky Zsoltnak és Dr. Szörényi Tamásnak, akik még egyetemi hallgatóként felkaroltak és rengeteg energiát befektetve indítottak el fizikusi pályámon.

Végül hálásan köszönöm feleségemnek, hogy a Ph.D. tanulmányaim során a kezdetektől fogva mellettem állt, biztatott és tartotta bennem a lelkesedést. Köszönöm Édesanyámnak, Édesapámnak, testvéremnek, és feleségem szüleinek, akik szintén támogattak a tanulmányaim során.

A dolgozatban ismertetett munkát a GINOP-2.3.2-15-2016-00001 számú pályázat támogatásával végeztem.

Szeged, 2019. június 26.

Buzás András

MTA SZBK Biofizika Intézet 


\section{Irodalomjegyzék}

[1] E. M. Purcell, „Life at low Reynolds number” American Journal of Physics 45, 3-11 (1977)

[2] T. Vicsek, A. Zafeiris, „Collective motion” Physics Reports 517, 71-140 (2012)

[3] I. Kavre, A. Vilfan, and D. Babic, „Hydrodynamic synchronization of autonomously oscillating optically trapped particles" Physical Review E 91, 031002 (2015)

[4] M. Polin, I. Tuval, K. Drescher, J. P. Gollub, and R. E. Goldstein, „Chlamydomonas Swims with Two "Gears" in a Eukaryotic Version of Run-and-Tumble Locomotion" Science 325, 487 (2009)

[5] S. Kernbach, ed., „Handbook of collective robotics fundamentals and challenges” Pan Stanford Publishing, 2013, ISBN 9789814316422, p.4

[6] N. Tarcai, C. Virágh, D.l. Ábel, M. Nagy, P. L. Várkonyi, G. Vásárhelyi and T.Vicsek, „Patterns, transitions and the role of leaders in the collective dynamics of a simple robotic flock” Journal of Statistical Mechanics: Theory and Experiment 2011, P04010 (2011)

[7] R. De Nardi and O. Holland, „Ultraswarm: A further step towards a flock of miniature helicopters" Swarm robotics 4433, 116-128 (2007)

[8] N. Michael, J. Fink and V. Kumar, „Cooperative manipulation and transportation with aerial robots" Autonomous Robots 30, 73-86 (2011)

[9] E. L. V. Delgado, ed., Interfacial Electrokinetics and Electrophoresis, CRC Press, 2002, ISBN 9780824706036, p.123

[10] H. Watarai, M. Suwa, Y. Iiguni, „Magnetophoresis and electromagnetophoresis of microparticles in liquids" Analytical and Bioanalytical Chemistry 378, 1693-1699 (2004)

[11] T. M. Vickrey, J. A. Garcia-Ramirez, „Magnetic field-flow fractionation: Theoretical basis" Separation Science and Technology 15, 1297-1304 (1980)

[12] R. Piazza, ,'Thermal forces': colloids in temperature gradients" Journal of Physics: Condensed Matter 16, S4195-S4211 (2004)

[13] H. J. Keh, Y. K. Wei, „Diffusiophoresis in a concentrated suspension of colloidal spheres in nonelectrolyte gradients" Colloid and Polymer Science 270, 539-546 (2000)

[14] J. P. Ebel, J. L. Anderson, D. C. Prieve, „Diffusiophoresis of latex particles in electrolyte gradients" Langmuir 4, 396-406 (1988) 
[15] M. M. Lin, D. C. Prieve, „Electromigration of latex induced by a salt gradient” Journal of Colloid and Interface Science 95, 327-339 (1983)

[16] S. M. Block, ,Making light work with optical tweezers” Nature 360, 493-495 (1992)

[17] A. Ashkin, ,History of optical trapping and manipulation of small-neutral particle, atoms, and molecules" IEEE Journal of Selected Topics in Quantum Electronics 6, 841-856 (2000)

[18] W. Paxton, S. Sundararajan, T. Mallouk, A. Sen, „Chemical locomotion” Angewadte Chemie Int. Ed. 45, 5420-5429 (2006)

[19] M. Ibele, T. E. Mallouk, and A. Sen, ,Schooling behavior of light-powered autonomous micromotors in water" Angewadte Chemie Int. Ed. 48, 3308-12 (2009)

[20] H-R. Jiang, N. Yoshinaga, and M. Sano, ,Active Motion of a Janus Particle by SelfThermophoresis in a Defocused Laser Beam" Physical Review Letters 105, 268302 (2010)

[21] J. K. G. Dhont, An Introduction to Dynamics of Colloids, Elsevier, ISBN: 9780444820099 , 1996, p. 227-247.

[22] L. D. Landau, E. M. Lifshitz, Fluid Mechanics (1966)

[23] S. Henderson, S. Mitchell, P. Bartlett, „Propagation of Hydrodynamic Interactions in Colloidal Suspensions" Physical Review Letters 88, (2002)

[24] L. E. Becker, S. A. Koehler, H. A. Stone, „On self-propulsion of micromachines at low Reynolds number: Purcell's three-link swimmer" Journal of Fluid Mechanics 490, 15-35 (2003)

[25] A. Najafi, R. Golestanian, „Simple swimmer at low Reynolds number: Threelinked spheres" Physical Review E 69, $062901-062904$ (2004)

[26] G. C. O'Kelly, „The terrestrial evolution of metabolism and life - by the numbers" Theoretical Biology and Medical Modelling 6, (2009)

[27] E. Lauga, T. R. Powers, „The hydrodynamics of swimming microorganisms” Reports on Progress in Physics 72, 096601 (2009)

[28] A. Pikovsky, M. Rosenblum and J. Kurths, Synchronization, Cambridge University Press, 2001, p. 1-17.

[29] Ch. Huygens, OEvres Compl'etes, volume 15., Swets \& Zeitlinger B. V., Amsterdam, 1967a.

[30] Ch. Huygens, OEvres Compl'etes, volume 17., Swets \& Zeitlinger B. V., Amsterdam, $1967 b$. 
[31] J-J. Mairan, „Observation botanique” Histoire de l'Académie royale des sciences avec les mémoires de mathématique et de physique tirés des registres de cette Académie (1729)

[32] H. Machemer, „Ciliary activity and the origin of metachrony in parameicum: effects of increased viscosity" Journal of Experimental Biology 57, 239-259 (1972)

[33] D. M. Woolley, R. F. Crockett, W. D. Groom and S. G. Revell, ,A study of synchronisation between the flagella of bull spermatozoa, with related" The Journal of Experimental Biology 212, 2215-2223 (2009)

[34] J. Gray, „Ciliary movement”, Cambridge University Press, 1928

[35] G. Taylor, „Analysis of the Swimming of Microscopic Organisms" Proceedings of the Royal Society A 209, 447-461 (1951)

[36] T. L. Jahn, and E. C. Bovee, „Movement and locomotion of microorganisms” Annual Review of Microbiology 19, 21-58 (1965)

[37] M. A. Sleigh, „Coordination of the rhythm of beat in some ciliary systems” International Review of Cytology 25, 31-54 (1969)

[38] L. Gheber and Z. Priel, „Synchronization between beating cilia” Biophysical Journal 55, 183-191 (1989)

[39] S. Gueron and N. Liron, „Ciliary motion modeling, and dynamic multicilia interactions” Biophysical Journal 63, 1045-1058 (1992)

[40] S. Gueron and N. Liron, „Simulations of Three-dimensional Ciliary Beats and Cilia Interactions" Biophysical Journal 65, 499-507 (1993)

[41] S. Gueron, K. Levit-Gurevich, N. Liron and J. L. Blum, „Cilia internal mechanism and metachronal coordination as the result of hydrodynamical coupling" Proceedings of the National Academy of Sciences 94, 6001-6006 (1997)

[42] S. Gueron and K. Levit-Gurevich, ,Energetic considerations of ciliary beating and the advantage of metachronal coordination" Proceedings of the National Academy of Sciences 96, 12240-12245 (1999)

[43] B. Guirao and J-F. Joanny, ,Spontaneous Creation of Macroscopic Flow and Metachronal Waves in an Array of Cilia" Biophysical Journal 92, 1900-1917 (2007)

[44] X. Yang, R. H. Dillon and L. J. Fauci, ,An Integrative Computational Model of Multiciliary Beating" Bulletin of Mathematical Biology 70, 1192-1215 (2008) 
[45] K. E. Machin, „Wave Propagation along flagella” Journal of Experimental Biology 35, 796-806 (1958)

[46] K. E. Machin, „The Control and Synchronization of Flagellar Movement” Proceedings of the Royal Society of London. Series B, Biological Sciences, 158, 88-104 (1963)

[47] C. J. Coakley and M. E. J. Holwill, „Propulsion of Micro-organisms by Three-dimensional Flagellar Waves" J. Theor. Biol. 35, 525-542 (1972)

[48] H. C. Berg, R. A. Anderson, „Bacteria Swim by Rotating their Flagellar Filaments” Nature 245, 380-382 (1973)

[49] J. G. Shoesmith, „The Measurement of Bacterial Motility” Microbiology 22, 528-535 (1960)

[50] H. C. Berg and D. A. Brown, „Chemotaxis in Escherichia coli analysed by Threedimensional Tracking” Nature 239, 500-504 (1972)

[51] B. A. D. Stocker, „Bacterial flagella; morphology, constitution and inheritance” Symposium of the Society for General Microbiology 6, 19 (1956)

[52] R. M. Macnab, „Bacterial flagella rotating in bundles: A study in helical geometry” Proceedings of the National Academy of Sciences 74, 221-225 (1977)

[53] MJ Kim, J. C. Bird, A. J. V. Parys, K. S. Breuer, and T. R. Powers, „A macroscopic scale model of bacterial flagellar bundling" Proceedings of the National Academy of Sciences 100, 15481-15485 (2003)

[54] B. Qian, H. Jiang, D. A. Gagnon, K. S. Breuer and T. R. Powers, ,Minimal model for synchronization induced by hydrodynamic interactions" Physical Review E 80, 061919 (2009)

[55] R. E. Goldstein, M. Polin, and I. Tuval, „Noise and Synchronization in Pairs of Beating Eukaryotic Flagella" Physical Review Letters 103, (2009)

[56] R. E. Goldstein, M. Polin, and I. Tuval, „Emergence of Synchronized Beating during the Regrowth of Eukaryotic Flagella" Physical Review Letters 107, 148103 (2011)

[57] B. M. Friedrich, and F. Jülicher, ,Flagellar Synchronization Independent of Hydrodynamic Interactions" Physical Review Letters 109, 138102 (2012)

[58] J. Kotar, M. Leonia, B. Bassetti, M. C. Lagomarsino and P. Cicuta, „Hydrodynamic synchronization of colloidal oscillators" Proceedings of the National Academy of Sciences 107, 7669-7673 (2010) 
[59] N. Bruot, L. Damet, J. Kotar, P. Cicuta, and M. C. Lagomarsino, „Noise and Synchronization of a Single Active Colloid' Physical Review Letters 107, 094101 (2011)

[60] J. Kotar, L. Debono, N. Bruot, S. Box, D. Phillips, S. Simpson, S. Hanna, and P. Cicuta, „Optimal Hydrodynamic Synchronization of Colloidal Rotors" Physical Review Letters 111, 228103 (2013)

[61] MJ. Kim and T. R. Powers, „Hydrodynamic interactions between rotating helices” Physical Review E 69, 061910 (2004)

[62] M. Reichert, and H. Stark, „Synchronization of rotating helices by hydrodynamic interactions" The European Physical Journal E 17, 493-500 (2005)

[63] P. Lenz, and A. Ryskin, „Collective effects in ciliar arrays” Physical Biology 3, 285-294 (2006)

[64] A. Vilfan, F. Jülicher, „Hydrodynamic Flow Patterns and Synchronization of Beating Cilia" Physical Review Letters 96, 058102 (2006)

[65] N. Uchida, and R. Golestanian, „Generic Conditions for Hydrodynamic Synchronization” Physical Review Letters 106, 058104 (2011)

[66] N. Uchida, and R. Golestanian, „Hydrodynamic synchronization between objects with cyclic rigid trajectories" The European Physical Journal E 35, 135 (2012)

[67] T. Niedermayer, B. Eckhardt, and P. Lenz, ,Synchronization, phase locking, and metachronal wave formationin ciliary chains" Chaos 18, 037128 (2008)

[68] J. Kepler, De Cometis Libelli Tres, 1619.

[69] J. Poynting, „On the Transfer of Energy in the Electromagnetic Field” Philosophical Transactions of the Royal Society of London 175, 343-361 (1884)

[70] P. N. Lebedev, „Untersuchungen über die Druckkräfte des Lichtes” Annalender Physik 6, 433 (1901)

[71] E. F. Nichols and G. F. Hull, „A Preliminary Communication on the Pressure of Heat and Light Radiation" Physical Review 13, 307 (1901)

[72] E. F. Nichols and G. F. Hull, „The Pressure Due to Radiation. (Second Paper.)” Physical Review Journal (Series I) 17, 26 (1903)

[73] A. Ashkin, „Acceleration and trapping of particles by radiation pressure” Physical Review Letters 24, 156-159 (1970) 
[74] S. Chu, J. E. Bjorkholm, A. Ashkin, and A. Cable, „Experimental observation of optically trapped atoms" Physical Review Letters 57, 314-317 (1986)

[75] B. K. Stuhl, B. C. Sawyer, D. Wang, and J. Ye, „Magneto-optical Trap for Polar Molecules" Physical Review Letters 101, 243002 (2008)

[76] E. S. Shuman, J. F. Barry and D. DeMille, „Laser cooling of a diatomic molecule” Nature 467, 820-823, 2010.

[77] M. H. Anderson, J. R. Ensher, M. R. Mathews, C. E. Wieman, and E. A. Cornell, „Observation Of Bose-Einstein Condensation in a dilute vapor below 200 nanokelvin” Science 269, 198 (1995)

[78] A. Ashkin and J. M. Dziedzic, „Optical trapping and manipulation of viruses and bacteria” Science 235, 1517-20 (1987)

[79] S. M. Block, D. F. Blair, and H. C. Berg, „Compliance of bacterial flagella measured with optical tweezers" Nature 338, 514-518 (1989)

[80] K. Svoboda, C. F. Schmidt, D. Branton, and S. M. Block, „Conformation and elasticity of the isolated red blood cell membrane skeleton" Biophysical Journal 63, 784-793 (1992)

[81] A. Ashkin, K. Schütze, J. M. Dziedzic, U. Eutenauer, and M. Schliwa, „Force generation of organelle transport measured in vivo by an infrared laser trap" Nature 348, 346-348 (1990)

[82] K. Svoboda, C. F. Schmidt, B. J. Schnapp, and S. M. Block, „Direct observation of kinesin stepping by optical trapping interferometry" Nature 365, 721-727 (1993)

[83] K. Svoboda, and S. M. Block, „Force and velocity measured for single kinesin molecules” Cell 77, 773-784 (1994)

[84] S. M. Block, „Nanometres and piconewtons: the macromolecular mechanics of kinesin” Trends in Cell Biology 5, 169-175 (1995)

[85] H. Yim, M. D. Wang, K. Svoboda, R. Landick, S. M. Block, and J. Gelles, „Transcription Against an Applied Force" Science 270, 1653-1657 (1995)

[86] Y. Hayasaki, M. Itoh, T. Yatagai, N. Nishida, „Nonmechanical Optical Manipulation of Microparticle Using Spatial Light Modulator" Optical Review 6, 24-27 (1999)

[87] J. Liesener, M. Reicherter, T. Haist, and H.J. Tiziani, ,Multi-functional optical tweezers using computer-generated holograms" Optics Communications 185, 77-82 (2000)

[88] D. G. Grier, ,A revolution in optical manipulation” Nature 424, 810-816 (2003) 
[89] M. Polin, K. Ladavac, S-H.Lee, Y. Roichman, and D. G. Grier, „Optimized holographic optical traps" Optics Express 13, (2005)

[90] J. Arlt, V. Garces-Chavez, W. Sibbett, and K. Dolakhia, „Optical manipulation using a Bessel light beam" Optics Communications 197, 239-245 (2001)

[91] S. H. Tao, W. M. Lee, and X-C. Yuan, ,Dynamic optical manipulation with a higher-order fractional Bessel beam generated from a spatial light modulator" Optics Letters 28, 18671869 (2003)

[92] J. E. Curtis, B. A. Koss, and D. G. Grier, ,Dynamic holographic optical tweezers” Optics Communications 207, 169-175 (2002)

[93] P. A. Prentice, M. P. MacDonald, T. G. Frank, A. Cuschieri, G. C. Spalding, W. Sibbett, P. A. Campbell, and K. Dholakia, ,Manipulation and filtration of low index particles with holographic Laguerre-Gaussian optical trap arrays" Optics Express 12, (2004)

[94] M. Dienerowitz, G. Gibson, R. Bowman, and M. Padgett, „Holographic aberration correction: optimising the stiffness of an optical trap deep in the sample" Optics Express 19, (2011)

[95] K. D. Wulff, D. G. Cole, R. L. Clark, R. Di Leonardo, J. Leach, J. Cooper, G. Gibson, and M. J. Padgett, „Aberration correction in holographic optical tweezers” Optics Express 14, (2006)

[96] T. Ota, T. Sugiura, S. Kawata, M. J. Booth, M. A. A. Neil, R. Juskaitis, and T. Wilson, „Enhancement of Laser Trapping Force by Spherical Aberration Correction Using a Deformable Mirror" Japanese Journal of Applied Physics 42, L701-L703 (2003)

[97] T. Cizmar, M. Mazilu, and K. Dholakia, ,In situ wavefront correction and its application to micromanipulation" Nature Photonics 4, 388-394 (2010)

[98] P. Galajda and P. Ormos, „Complex micromachines produced and driven by light” Applied Physics Letters 78, 249 (2001)

[99] M. E. J. Friese, H. Rubinsztein-Dunlop, J. Gold, P. Hagberg, and D. Hanstorp, „Optically driven micromachine elements" Applied Physics Letters 78, 547 (2001)

[100] B. L. Aekbote, T. Fekete, J. Jacak, G. Vizsnyiczai, P. Ormos, and L. Kelemen, „Surfacemodified complex SU-8 microstructures for indirect optical manipulation of single cells" Biomedical Optics Express 7, (2015) 
[101] A. Ashkin, ,Forces of a single-beam gradient laser trap on a dielectric sphere in the ray optics regime" Biophysical Journal 61, 569-582 (1992)

[102] W.H. Wright, G.J. Sonek, Y. Tadir, and M. W. Berns, „Laser Trapping in Cell Biology” IEEE Journal of Quantum Electronics 26, 12 (1990)

[103] T. C. B. Schut, G. Hesselink, B. G. de Grooth, and J. Greve, ,Experimental and Theoretical Investigations on the Validity of the Geometrical Optics Model for Calculating the Stability of Optical Traps" Cytometry 12, 479-485 (1991)

[104] R. Gussgard, T. Lindmo, and I. Brevik, „Calculation of the trapping force in a strongly focused laser beam" Journal of the Optical Society of America B 9, 10 (1992)

[105] A. Callegari, M. Mijalkov, A.B. Gököz and G. Volpe, „Computational toolbox for optical tweezers in geometrical optics" Journal of the Optical Society of America B 32, B11-B19 (2015)

[106] Y. Harada, and T. Asakura, ,Radiation forces on a dielectric sphere in the Rayleigh scattering regime" Optics Communications 124, 529-541 (1996)

[107] J. P. Barton, D. R. Alexander, and S. A. Schaub, „Internal and near surface electromagnetic fields for a spherical particle irradiated by a focused laser beam" Journal of Applied Physics 64, 1632 (1988)

[108] J. P. Barton, D. R. Alexander, and S. A. Schaub, „Theoretical determination of net radiation force and torque for a spherical particle illuminated by a focused laser beam" Journal of Applied Physics 66, 4594 (1989)

[109] O. Farsund, and B.U. Felderhof, „Force, torque, and absorbed energy for a body of arbitrary shape and constitution in an electromagnetic radiation field" Physica A 227, 108-130 (1996)

[110] D. Ganic, X. Gan, and M. Gu, „Exact radiation trapping force calculation based on vectorial diffraction theory" Optics Express 12, (2004)

[111] A. Rohrbach and E. H. K. Stelzer, „Optical trapping of dielectric particles in arbitrary fields" Journal of the Optical Society of America A 18, 839-853 (2001)

[112] A. Rohrbach and E. H. K. Stelzer, „Trapping forces, force constants, and potential depths for dielectric spheres in the presence of spherical aberrations" Applied Optics 41, 24942507 (2002) 
[113] T. A. Nieminen, H. Rubinsztein-Dunlop, N. R. Heckenberg and A. I. Bishop, „Numerical Modelling of Optical Trapping" Computer Physics Communications 142, 468-471 (2001)

[114] E. M. Purcell, and C. R. Pennycracker, „Scattering and absorption of lightby non-spherical dielectric grains" The Astrophysical Journal 186, 705-714 (1973)

[115] D. Bonessi, K. Bonin, and T. Walker, „Optical forces on particles of arbitrary shape and size” Journal of Optics A: Pure and Applied Optics 9, S228-S234 (2007)

[116] S. H. Simpson and S. Hanna, ,Application of the discrete dipole approximation to optical trapping calculations of inhomogeneous and anisotropic particles" Optics Express 19, (2011)

[117] A. R. Zakharian, M. Mansuripur, and J. V. Moloney, „Radiation pressure and the distribution of electromagnetic force in dielectric media" Optics Express 13, 2321-2336 (2005)

[118] R. C. Gauthier, „Computation of the optical trapping force using an FDTD based technique" Optics Express 13, 3707-3718 (2005)

[119] G. Roosen and C. Imbert, „Optical levitation by means of two horizontal laser beams: A theoretical and experimental study" Physics Letters A 59, 6-8 (1976)

[120] K. C. Neuman, and S. M. Block, „Optical trapping” Review of Scientific Instruments 75, 2787-2809 (2004)

[121] H. Liang, K. T. Vu, P. Krishnan, T. C. Trang, D. Shin, S. Kimel, and M. W. Berns, „Wavelength Dependence of Cell Cloning Efficiency after Optical Trapping” Biophysical Journal 70, 1529-1533 (1996)

[122] P. Galajda and P. Ormos, „Orientation of flat particles in optical tweezers by linearly polarized light' Optics Express 11, 446-51 (2003)

[123] M. E. J. Friese, T. A. Nieminen, N. R. Heckenberg, and N. R. Rubinsztein-Dunlop, „Optical alignment and spinning of laser-trapped microscopic particles” Nature 394, 348350 (1998)

[124] R. Di Leonardo, F. Ianni, G. Ruocco, „Computer generation of optimal holograms for optical trap arrays" Optics Express 15, (2007)

[125] M. Reicherter, T. Haist, E. U. Wagemann, and H. J. Tiziani, „Optical particle trapping with computer-generated holograms written on a liquid-crystal display" Optics Letters 24, (1999) 
[126] E. R. Dufresne, G. C. Spalding, M. T. Dearing, S. A. Sheets, D. G. Grier, „Computergenerated holographic optical tweezers arrays" Review of Scientific Instruments 72, 1810-1816 (2001)

[127] K. Svoboda, S. M. Block, „Biological applications of optical forces” Annual Review of Biophysics and Biomolecular Structure 23, 247-285 (1994)

[128] H.-I. Kim, I.-J. Joo, S.-H. Song, P.-S. Kim, K.-B. IM, and C.-H. Oh, „Dependence of the optical trapping efficiency on the ratio of the beam radius-to-the aperture radius" Journal of the Korean Physical Society 43, 348-351 (2003)

[129] M. Mahamdeh, C. P. Campos and E. Schaffer, „Under-filling trapping objectives optimizes the use of the available laser power in optical tweezers" Optics Express 19, 11759-11768 (2011)

[130] M. Bing-Huan, Z. Jin-Hua, Z. Min-Cheng, L. Yin-Mei, W. Jian-Guang, R. Hong-Liang, „Improvement of transverse trapping efficiency of optical tweezers” Chinese Physics Letters 25, 2300-2302 (2008)

[131] A. Samadi and N. S. Reihani, „Optimal beam diameter for optical tweezers” Optics Letters 35, 1494-1496 (2010)

[132] J. W. Goodman, Introduction to Fourier Optics 2nd Ed., McGraw-Hill Companies, Inc., 1996, p. 101-107.

[133] H-B. Sun, and S. Kawata, „Two-Photon Photopolymerization and 3D Lithographic Microfabrication" APS 170, 169-273 (2004)

[134] S. Kawata, H-B. Sun, T. Tanaka, and K. Takada, „Finer features for functional microdevices" Nature 412, 697-698 (2001)

[135] T. Tanaka, H-B. Sun, and S. Kawata, „Rapid sub-diffraction-limit laser micro/nanoprocessing in a threshold material system" Applied Physics Letters 80, 312 (2002)

[136] H-B. Sun, M. Maeda, K. Takada, J. W. M. Chon, M. Gu, and S. Kawata, „Experimental investigation of single voxels for laser nanofabrication via two-photon photopolymerization" Applied Physics Letters 83, 819-821 (2003)

[137] J. Fischer, and M. Wegener, „Three-dimensional direct laser writing inspired by stimulated-emission-depletion microscopy” Optical Material Express 1, (2011) 
[138] J. Fischer, and M. Wegener, „Three-dimensional optical laser lithography beyond the diffraction limit" Laser phoonics Review 7, 22-44 (2013)

[139] S. K. Mitra, and S. Chakraborty, editors, Microfluidics and Nanofluidics Handbook: Fabrication, Implementation, and Applications, CRC Press, ISBN 9781138072381, 2011, p. 231-269.

[140] L. D. Landau, E. M. Lifshitz, „Statistical Physics part 1.”, Pergamon Press, 1980, p. 396400 .

[141] R. Fürth, „Die Brownsche Bewegung bei Beriicksichtigung einer Persistenz der Bewegungsrichtung. Mit Anwendungen auf die Bewegung lebender Infusorien” Z. Phys. 2, p. 244 (1920)

[142] D. Selmeczi, S. Mosler, P. H. Hagedorn, N. B. Larsen, and H. Flyvbjerg, „Cell Motility as Persistent Random Motion: Theories from Experiments" Biophysical Journal 89, (2005) 912-931

[143] Miles V. Klein, „Optics”, John Wiley \& Sons Inc., 1970, p. 123. 


\section{Magyar nyelvü összefoglaló}

A mikroszkopikus biológiai rendszerek mozgása nagyon különbözik attól, ahogy a makro világunkban látott testek mozognak. E kérdéskör rendkívül érdekes és fontos mind elméleti, mind pedig gyakorlati szempontból, és számos, szerteágazó, jellegzetes kérdéskört érint. Nagyon fontos gyakorlati cél például a bakteriális fertőzések megelőzése, legyőzése. Ehhez a fertőzés folyamatának pontos jellemzése szükséges. A baktériumok (egyedi, illetve nagyszámú egyed együttes) mozgásának jobb megismerése nyilvánvalóan közelebb visz a problémakör kezeléséhez. Általában igaz, mára nyilvánvalóvá vált, hogy a makroszkopikus biológiai jelenségek megértéséhez elengedhetetlen, hogy megismerjük a mikroszkopikus folyamatok részleteit. A baktériumok mozgása sajátos fizikai problémakör. Ismert, hogy a kis Reynolds-számmal jellemezhető rendszerekben az úszás mechanizmusa nagyon más, mint a makroszkopikus világban, a lehetséges megvalósulások részletes jellemzése még távolról sem teljes. Sok érdekes hatást is megfigyeltek e világban, pl. az egymás közelében mozgó részecskék hidrodinamikai kölcsönhatása, kollektív mozgása, bizonyos mozgások szinkronizációja, stb. - szükség lenne e jelenségek nagy pontosságú jellemzésére, kvantitatív leírására.

Az fent említett jelenségkörökben kulcsszerepe van a folyamatok kísérleti vizsgálatának, amelyek egyrészt alapul szolgálnak az elméletek létrehozásához, másrészt az elméletek ellenőrzését is a megfelelő kísérletekkel lehet elvégezni. A teljes leíráshoz szükséges kísérleteket elvileg a természetes rendszereken legjobb végezni. A természetes rendszereken végzett kísérletek azonban lényeges korlátja, hogy ezek általában nagyon bonyolultak, számos paraméterük nem ismert elegendő pontossággal. Ráadásul, a fizikai modellek ellenőrzéséhez általában szükséges a paraméterek változtatása - a természetes rendszereken erre rendszerint csak nagyon korlátozottan van lehetőség. Ilyen problémák nagyban megnehezítik a kvantitatív modellalkotást. A probléma egyik magától értetődő megoldása mesterséges kísérleti modellrendszer, robotok alkalmazása. A mozgó rendszerek részletes jellemzésében nagy segítséget nyújtanának olyan mesterséges modellek, amelyek a természetes müködést lehetöleg minél több szempontból hủen reprezentálják, ugyanakkor paraméterei pontosan ismertek, változtathatók, ezáltal az elméleti modellek ellenőrizhetősége könnyebbé válik. Ilyen rendszerek fejlesztését és tanulmányozását tüztem ki célul. 


\section{Tézispont}

Kialakítottam egy fénnyel hajtott mikrorobot/mikroúszó rendszert. A rendszerben az egyes részecskék önállóan mozognak, abban az értelemben, hogy mozgásukhoz az energiát a fényből nyerik, de mozgásuk irányára a fény nincs hatással. A részecskék fotopolimerizációval előállított ékek, amelyeket aranyréteggel vontam be. $\mathrm{E}$ részecskék mozgását tanulmányoztam megvilágítás hatására.

Demonstráltam, hogy e testek képesek megvilágítás hatására mozogni mind víz/üveg, mind víz/levegő határfelületen. A mozgásuk sebessége - ami tipikusan $10 \mu \mathrm{m} / \mathrm{s}$ - arányos a megvilágító fényforrás lokális intenzitásával, míg irányát a testek helyzete határozza meg. A mozgások pályájából kétféle módszerrel is meghatároztam az ékek mozgására jellemző perzisztencia hosszat, ez $100-1000 \mu \mathrm{m}$ nagyságrendü volt. A perzisztenciahossz az ékek méreténél 1-2 nagyságrenddel nagyobb volt. [T1]

\section{Tézispont}

Mikroszkopikus, fénnyel hajtott autonóm módon mozgó guriga kivitelü testet készítettem, amelynek olyan az alakja, hogy a forgástengelyére merőlegesen érkező megvilágítás hatására gördülni kezd a helyzete által meghatározott irányban.

Ilyen, fotopolimerizációval előállított és aranyréteggel bevont 3 dimenziós gurigák mozgását vizsgáltam. A gurigák megvilágítására olyan optikai elrendezést alkalmaztam, amely alulról és felülről is megvilágította a gurigákat, ahol az alsó megvilágítás szerepe elsősorban a súrlódás csökkentetése volt. Kísérletekkel bebizonyítottam, hogy megfelelő alakú gurigák valóban képesek a fény által hajtott folyamatos forgásra, a megfelelő irányú mozgásra. [T2]

\section{Tézispont}

Elméleti bizonyítását adtam, hogy a prizmaszerü struktúrák nem képesek a forgástengelyre merőlegesen érkező homogén megvilágítás hatására folyamatosan forogni. A bizonyításban központi szerepet játszik, hogy i) veszteségmentes (lineáris) optikai rendszerben a radiancia megmaradó mennyiség, ii) egy oldalról homogén módon megvilágítva a struktúrát és körbeforgatva mechanikai hatás szempontjából ekvivalens azzal esettel, mintha izotróp sugárzási térbe helyeznénk a struktúrát. A bizonyítást mind teljesen fényvisszaverō, mind pedig átlátszó struktúra esetére elvégeztem. 
A megfigyelések és bizonyítások összegzéseként az alábbi általános állítást fogalmaztam meg: Szóró testtel kölcsönható, impulzusmomentumot nem hordozó kollimált nyaláb nem hozhat létre folyamatos forgást, ha a fényszórás kétdimenziós és a kölcsönhatás veszteségmentes. A fény hajtotta forgás szükséges, de nem elegendő feltétele, hogy a fényszórás 3 dimenziós legyen. [T2]

\section{Tézispont}

Demonstráltam, hogy a hidrodinamikai kölcsönhatás képes vízbe merülö mikrorotorok forgását szinkronizálni. A kísérleti demonstrációban optikai csipesszel csapdázott két mikrorotor forgását elemeztem nagyon finoman szabályozott paraméterek (forgási sebesség, a rotorok egymástól mért távolsága, stb.) mellett.

Analitikus modellt dolgoztam ki a szinkronizáció modellezésére. A rotorok fáziskülönbségének dinamikáját a sztochasztikus Adler egyenlet megoldásával modelleztem, ami egy Brown részecske mozgását írja le egy döntött potenciál gödörben. A két rotor forgási fáziskülönbségeinek eloszlását a Fokker-Planck egyenlet megoldásával nyertem. [T3] 


\section{Angol nyelvü összefoglaló}

The movement of microscopic biological systems is very different from what we can observe in our macro world. This issue is extremely interesting and important, both theoretically and practically. A very important practical goal is to prevent and overcome bacterial infections. This requires a precise characterization of the infection process. A better understanding of the movement of bacteria (single or a large number of individuals together) is necessary to treat the problem. In systems characterized with small Reynolds number the swimming mechanism is very different from that in the macroscopic world, the detailed characterization of possible realizations is far from complete. There have been observed many interesting phenomena in this regime, for example, the hydrodynamic interaction, the collective movement of swimming objects, the synchronization of certain movements, and so on - it would be necessary to characterize and quantitatively describe them.

The experimental examination of processes plays a key role in the understanding of the abovementioned phenomena. On one hand, it serves as a basis for the generation of theories, on the other hand, verification of the theories can be carried out with appropriate experiments. In principle, experiments for the full description are best performed on natural systems. However, experiments on natural systems have an essential limitation because they are very complex, in addition, many of their parameters are not known with sufficient precision. Futhermore, in order to characterize the physical models, it is also necessary to vary the parameters - in natural systems this is problematic, too. Due to these problems quantitative modeling is difficult. One solution to this problem is the use of artificial experimental model systems, robots. In the detailed characterization of the moving systems such artificial models would be very helpful that represent the natural function as faithfully as possible from as many aspects as possible, but its parameters are known with high accuracy and can be changed so that the theoretical models can be easily verified. In my dissertation, I set the goal to design microscopic robot systems to investigate two classes of phenomena: microscopic motion and hydrodynamic synchronization. 


\section{Thesis 1}

I created a light-driven microrobot system. In the system, each particle moves independently, in the sense that the energy is obtained from the light for their movement, but the light has no effect on the direction of their movement. The particles are wedges made by photopolymerization and coated with gold. I studied the movement of these particles under the influence of illumination.

I demonstrated that microrobots can move due to illumination at both water/glass and water/air interfaces. The energy required for their movement was obtained from the illumination light. The speed of their movement, which is typically $10 \mu \mathrm{m} / \mathrm{s}$, is proportional to the local intensity of the illumination, while the direction of the movement is determined by the orientation of the structures. I determined the persistence length from the trajectory of motions using the worm-like-chain and the persistent-random-walk model, which ranged from 100 to $1000 \mu \mathrm{m}$. The persistence length of the wedges was 1-2 orders of magnitude higher than its size. [T1]

\section{Thesis 2}

I prepared microscopic, autonomously moving rollers with a shape that facilitates rolling in the direction determined by its orientation, upon illumination from a direction perpendicular to its axis of rotation.

I investigated the movement of 3-dimensional rollers produced by photopolymerization and coated with gold layer. I used an optical arrangement to illuminate the rollers where illumination came both from the top and bottom, where the role of lower illumination was primarily to reduce friction. Experiments have shown that rollers of appropriate shape are capable of continuous light-driven rotation and movement in the expected direction. [T2]

\section{Thesis 3}

I gave theoretical evidence that prismatic structures are unable to rotate continuously due to homogeneous illumination perpendicular to the axis of rotation. In the proof, it is fundamental that i) the radiance is a remaining quantity in a lossless (linear) optical system, ii) homogeneously illuminating the structure from one side and rotating it is equivalent to 
the situation when the structure is placed in isotropic illumination. The proof was performed for both fully reflective and transparent structures.

As a summary of the observations and demonstrations I have formulated the following general statement: A collimated beam can not generate continuous rotation if the light scattering is two-dimensional and the interaction is lossless. For the light-driven rotation it is necessary, but not sufficient that the light scattering is 3-dimensional. [T2]

\section{Thesis 4}

I demonstrated that the hydrodynamic interaction is capable of synchronizing the rotation of two micro-motors immersed in water. In the experimental demonstration I analyzed the dependency of synchronization on the finely controlled ratio of the rotation speed and the distance between the two rotors.

I have developed an analytical model for modeling synchronization. The dynamics of the phase difference of the rotors was modeled by the stochastic Adler equation, that describes the movement of a Brown particle in a tilted potential. The distribution of the phase differences of the two rotor was obtained by solving the Fokker-Planck equation. [T3] 